Наџіональна академія правових наук України

Наџіональний юридичний університет імені Ярослава Мудрого
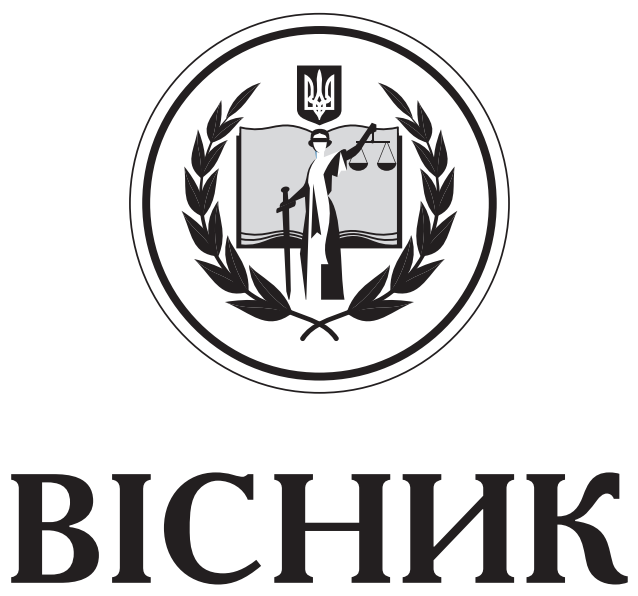

\title{
НАЦІОНАЛЬНОÏ АКАДЕМIÏ
} ПРАВОВИХ НАУК УКРАЇНИ

\author{
Заснований у 1993 роиі
}

Періодичність випуску - 4 номери на рік

\section{Том 26, № 1 2019}

Харків

«Право»

2019 
DOI: 10.31359/1993-0909-2019-26-1

Рекомендовано до друку вченою радою

Національного юридичного університету імені Ярослава Мудрого

(протокол № 10 від 29 березня 2019 р.)

Свідоцтво про державну ресстрацію

Серія КВ № 19889-9689Р від 09.04.2013 р.

Видання внесено до Переліку наукових фахових видань у галузі юридичних наук

(наказ МОН України № 241 від 09.03.2016р.)

\section{Видання включено до міжнародної наукометричної бази}

Index Copernicus International

(Варшава, Польща)

Вісник Національної академії правових наук України / редкол.: О. Петришин та ін. - Харків : Право, 2019. - Т. 26, № 1. - 176 с.

\section{Засновники:}

Національна академія правових наук України

Національний юридичний університет імені Ярослава Мудрого

\section{Видавець:}

Національна академія правових наук України

\section{Відповідальний за випуск \\ О. В. Петришин}

Матеріали друкуються українською, російською та англійською мовами

Адреса редакційної колегії: 61024, Харків, вул. Пушкінська, 70, Національна академія правових наук України. Тел. (057) 707-79-89

Офіційний сайт: visnyk.kh.ua

e-mail: visnyk_naprnu@ukr.net

(C) Національна академія правових наук України, 2019 
National Academy of Legal Sciences of Ukraine Yaroslav Mudryi National Law University
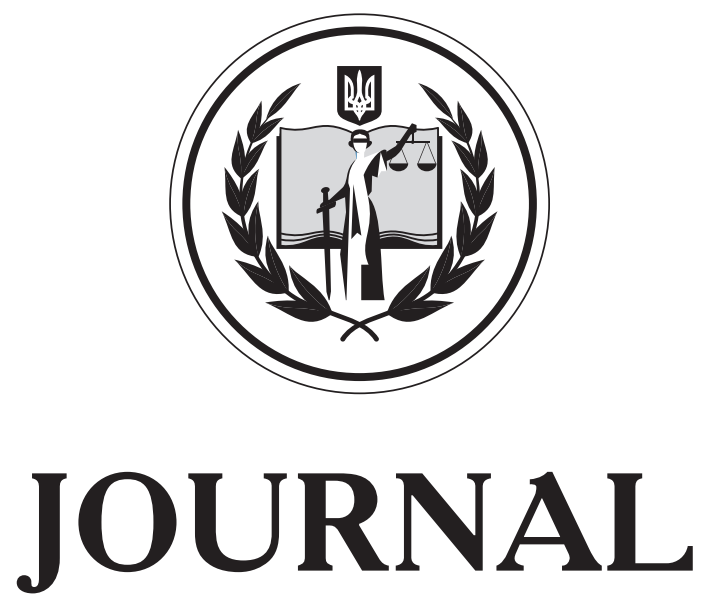

OF THE NATIONAL ACADEMY OF LEGAL SCIENCES OF UKRAINE

Founded in 1993

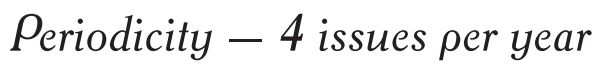

\section{Volume 26, Issue 1 2019}

Kharkiv «Pravo» 2019 
UDC 34

ISSN 1993-0909

DOI: 10.31359/1993-0909-2019-26-1

Recommended for publication by the academic Council

Yaroslav Mudryi National Law University

(Protocol № 10 dated 29 March 2019)

The certificate of state registration

KB № 19889-9689P date 09.04.2013

Journal included in the List

of scientific professional publications in the field of legal Sciences

(the order of MES of Ukraine No. 241 dated on 09.03.2016)

Journal included in the international scientometric databases

Index Copernicus International

(Warsaw, Poland)

Journal of the National Academy of Legal Sciences of Ukraine / editorial board:

O. Petryshyn et al. - Kharkiv : Pravo, 2019. - Vol. 26, № 1. - 176 p.

The founders:

National Academy of Legal Sciences of Ukraine

Yaroslav Mudryi National Law University

Publisher:

National Academy of Legal Sciences of Ukraine

Responsible for the release of

O. V. Petryshyn

Materials are published in Ukrainian, Russian and English

The Editorial Board address: 61024, Kharkiv, 70 Pushkinska Street, National Academy of Legal Sciences of Ukraine. Ph.: (057) 707-79-89

Official website: visnyk.kh.ua

e-mail: visnyk_naprnu@ukr.net

(C) 2019 National Academy of Legal Sciences of Ukraine 


\section{НАУКОВА РАДА ВІСНИКА}

Василь Тацій - доктор юридичних наук, професор, академік НАН України та НАПрН України (голова наукової ради) (Національний юридичний університет імені Ярослава Мудрого, Україна);

Юрій Барабаш - доктор юридичних наук, професор, член-кореспондент НАПрН України (Національний юридичний університет імені Ярослава Мудрого, Україна);

Юрій Баулін - доктор юридичних наук, професор, академік НАПрН України (Національний юридичний університет імені Ярослава Мудрого, Україна);

Вячеслав Борисов - доктор юридичних наук, професор, академік НАПрН України (Науково-дослідний інститут вивчення проблем злочинності імені академіка В. В. Сташиса Національної академії правових наук України, Україна);

Валентина Борисова - кандидат юридичних наук, професор, член-кореспондент НАПрН України (Національний юридичний університет імені Ярослава Мудрого, Україна);

Володимир Гаращук - доктор юридичних наук, професор, член-кореспондент НАПрН України (Національний юридичний університет імені Ярослава Мудрого, Україна);

Володимир Голіна - доктор юридичних наук, професор, член-кореспондент НАПрН України (Національний юридичний університет імені Ярослава Мудрого, Україна);

Володимир Гончаренко - доктор юридичних наук, професор, академік НАПрН України (Національний юридичний університет імені Ярослава Мудрого, Україна);

Володимир Журавель - доктор юридичних наук, професор, академік НАПрН України (Національна академія правових наук України, Україна);

Оксана Капліна - доктор юридичних наук, професор, член-кореспондент НАПрН України (Національний юридичний університет імені Ярослава Мудрого, Україна);

Вячеслав Комаров - кандидат юридичних наук, професор, академік НАПрН України (Національний юридичний університет імені Ярослава Мудрого, Україна);

Олександр Крупчан - доктор юридичних наук, професор, академік НАПрН України (Науково-дослідний інститут приватного права і підприємництва імені академіка Ф. Г. Бурчака Національної академії правових наук України, Україна);

Микола Кучерявенко - доктор юридичних наук, професор, академік НАПрН України (Національний юридичний університет імені Ярослава Мудрого, Україна);

Василь Лемак - доктор юридичних наук, професор, член-кореспондент НАПрН України (Конституційний Суд України, Україна);

Сергій Максимов - доктор юридичних наук, професор, член-кореспондент НАПрН України (Національний юридичний університет імені Ярослава Мудрого, Україна);

Олена Орлюк - доктор юридичних наук, професор, академік НАПрН України (Науководослідний інститут інтелектуальної власності Національної академії правових наук України, Україна);

Микола Панов - доктор юридичних наук, професор, академік НАПрН України (Національний юридичний університет імені Ярослава Мудрого, Україна);

Володимир Пилипчук - доктор юридичних наук, професор, член-кореспондент НАПрН України (Науково-дослідний інститут інформатики і права Національної академії правових наук України, Україна);

Сергій Прилипко - доктор юридичних наук, професор, академік НАПрН України (Вища кваліфікаційна комісія суддів України, Україна);

Петро Рабінович - доктор юридичних наук, професор, академік НАПрН України (Львівський національний університет імені Івана Франка, Україна); 
В'ячеслав Рум'янцев - доктор юридичних наук, професор, член-кореспондент НАПрН України (Національний юридичний університет імені Ярослава Мудрого, Україна);

Олександр Святоцький - доктор юридичних наук, професор, академік НАПрН України (Видавництво «Право України», Україна);

Анатолій Селіванов - доктор юридичних наук, професор, академік НАПрН України (Верховна Рада України, Україна);

Інна Спасибо-Фатєєва - доктор юридичних наук, професор, член-кореспондент НАПрН України (Національний юридичний університет імені Ярослава Мудрого, Україна);

Володимир Тихий - доктор юридичних наук, професор, академік НАПрН України (Національна академія правових наук України, Україна);

Юрій Шемшученко - доктор юридичних наук, професор, академік НАН України та НАПрН України (Інститут держави і права імені В. М. Корецького Національної академії наук України, Україна);

Валерій Шепітько - доктор юридичних наук, професор, академік НАПрН України (Національний юридичний університет імені Ярослава Мудрого, Україна);

Ольга Шило - доктор юридичних наук, професор, член-кореспондент НАПрН України (Національний юридичний університет імені Ярослава Мудрого, Україна);

Михайло Шульга - доктор юридичних наук, професор, член-кореспондент НАПрН України (Національний юридичний університет імені Ярослава Мудрого, Україна)

\section{РЕДАКЦІЙНА КОЛЕГІЯ}

Олександр Петришин - доктор юридичних наук, професор, академік НАПрН України (голова редакційної колегії) (Національна академія правових наук України, Україна);

Теофіль Асслер - професор (Університет Страсбурга, Франція);

Флавіус Антоній Байас - професор (Бухарестський Університет, Румунія);

Юрген Базедов - професор (Інститут іноземного та міжнародного приватного права імені Макса Планка, Німеччина);

Вільям Еліот Батлер - професор (Школа права, Університет штату Пенсильванія, США);

Серджио Биешу - доктор юридичних наук, професор (Факультет права, Молдавський державний університет, Молдова);

Юрій Битяк - доктор юридичних наук, професор, академік НАПрН України (Національний юридичний університет імені Ярослава Мудрого, Україна);

Станіслав Бука - професор (Балтійська міжнародна академія, Латвія);

Ермек Бурібаєв - доктор юридичних наук, професор (Казахський національний педагогічний університет імені Абая, Республіка Казахстан);

Чаба Варга - професор (Інститут правових досліджень, Угорська академія наук, Угорщина);

Анатолій Гетьман - доктор юридичних наук, професор, академік НАПрН України (Національний юридичний університет імені Ярослава Мудрого, Україна);

Свген Гетьман - доктор юридичних наук, професор (Національна академія правових наук України, Україна)

Андрій Гриняк - доктор юридичних наук, професор (Науково-дослідний інститут приватного права і підприємництва імені академіка Ф. Г. Бурчака Національної академії правових наук України, Україна)

Костянтин Гусаров - доктор юридичних наук, професор (Національний юридичний університет імені Ярослава Мудрого, Україна); 
Наталія Гуторова - доктор юридичних наук, професор (Полтавський юридичний інститут Національного юридичного університету імені Ярослава Мудрого, Україна);

Томас Давуліс - професор (Вільнюський державний університет, Литва);

Томас Жиаро - професор (Варшавський університет, Польща);

Микола Іншин - доктор юридичних наук, професор, академік НАПрН України (Київський національний університет імені Тараса Шевченка, Україна);

Фархад Кагарусов - доктор юридичних наук, професор (Інститут приватного права Каспійського університету, Республіка Казахстан);

Емануель Кастелляран - професор (Університет Страсбурга, Франція);

Карл-Герман Кестнер - професор (Університет м. Тюбінген, Німеччина);

Рольф Кніпер - професор (Університет Гете, Німеччина);

Танел Керікмае - професор (Школа права, Талліннський технічний університет, Естонія);

Анатолій Коструба - доктор юридичних наук, професор (Прикарпатський національний університет імені Василя Стефаника, Україна);

Олексій Кот - доктор юридичних наук, старший дослідник (Науково-дослідний інститут приватного права і підприємництва імені академіка Ф. Г. Бурчака Національної академії правових наук України, Україна);

Наталія Кузнсцова - доктор юридичних наук, професор, академік НАПрН України (Національна академія правових наук України, Україна);

Райнер Кульмс - професор (Інститут іноземного та міжнародного приватного права імені Макса Планка, Німеччина);

Йошіке Курумісава - професор (Школа права, Університет Васеда, Японія);

Ірина Лукач - доктор юридичних наук, професор (Київський національний університет імені Тараса Шевченка, Україна);

Снєголе Матюльєне - професор (Університет імені Миколаса Ромеріса, Литва);

Катерін Меа - професор (Лісабонський університет, Португалія);

Василь Настюк - доктор юридичних наук, професор, член-кореспондент НАПрН України (Національний юридичний університет імені Ярослава Мудрого, Україна);

Конрад Осайда - доктор філософії в галузі права (Варшавський університет, Польща);

Мар'яна Пленюк - доктор юридичних наук, професор (Науково-дослідний інститут приватного права і підприємництва імені академіка Ф. Г. Бурчака Національної академії правових наук України, Україна);

Світлана Серьогіна - доктор юридичних наук, професор, член-кореспондент НАПрН України (Науково-дослідний інститут державного будівництва та місцевого самоврядування Національної академії правових наук України, Україна);

Ізабела Скомерська-Муховська - професор (Лодзинський університет, Польща);

Кирило Томашевський - доктор юридичних наук, доцент (Установа освіти Федерації профспілок Білорусі «Міжнародний університет "МИТСО"», Республіка Білорусь);

Жанна Хамзіна - доктор юридичних наук, професор (Казахський національний університет імені Абая, Республіка Казахстан);

Віктор Шевчук - доктор юридичних наук, професор (Національний юридичний університет імені Ярослава Мудрого, Україна);

Ханс Іоахім Шрамм - професор (Інститут Східного права Університету технології, бізнесу і дизайну, Німеччина);

Іван Яковюк - доктор юридичних наук, професор (Національний юридичний університет імені Ярослава Мудрого, Україна);

Олег Ярошенко - доктор юридичних наук, професор, член-кореспондент НАПрН України (Національний юридичний університет імені Ярослава Мудрого, Україна) 


\section{SCIENTIFIC COUNCIL OF THE JOURNAL}

Vasyl Tatsii - Doctor of Juridical Science, Professor, Academician of the National Academy of Sciences of Ukraine and the National Academy of Legal Sciences of Ukraine (Chairman of the Scientific Council) (Yaroslav Mudryi National Law University, Ukraine);

Yurii Barabash - Doctor of Juridical Science, Professor, Corresponding Member of the National Academy of Legal Sciences of Ukraine (Yaroslav Mudryi National Law University, Ukraine);

Yurii Baulin - Doctor of Juridical Science, Professor, Academician of the National Academy of Legal Sciences of Ukraine (Yaroslav Mudryi National Law University, Ukraine);

Viacheslav Borysov - Doctor of Juridical Science, Professor, Academician of the National Academy of Legal Sciences of Ukraine (Scientific and Research Institute for Study of Crime Problems named after Academician V.V. Stachys of the National Academy of Legal Sciences of Ukraine, Ukraine);

Valentyna Borysova - Candidate of Juridical Science, Professor, Corresponding Member of the National Academy of Legal Sciences of Ukraine (Yaroslav Mudryi National Law University, Ukraine);

Volodymyr Garashchuk - Doctor of Juridical Science, Professor, Corresponding Member of the National Academy of Legal Sciences of Ukraine (Yaroslav Mudryi National Law University, Ukraine);

Volodymyr Golina - Doctor of Juridical Science, Professor, Corresponding Member of the National Academy of Legal Sciences of Ukraine (Yaroslav Mudryi National Law University, Ukraine);

Volodymyr Goncharenko - Doctor of Juridical Science, Professor, Academician of the National Academy of Legal Sciences of Ukraine (Yaroslav Mudryi National Law University, Ukraine);

Volodymyr Zhuravel - Doctor of Juridical Science, Professor, Academician of the National Academy of Legal Sciences of Ukraine (The National Academy of Legal Sciences of Ukraine, Ukraine);

Oksana Kaplina - Doctor of Juridical Science, Professor, Corresponding Member of the National Academy of Legal Sciences of Ukraine (Yaroslav Mudryi National Law University, Ukraine);

Viacheslav Komarov - Candidate of Juridical Science, Professor, Academician of the National Academy of Legal Sciences of Ukraine (Yaroslav Mudryi National Law University, Ukraine);

Oleksandr Krupchan - Doctor of Juridical Science, Professor, Academician of the National Academy of Legal Sciences of Ukraine (Scientific and Research Institute of Private Law and Entrepreneurship named after Academician F. G. Burchak of the National Academy of Legal Sciences of Ukraine, Ukraine);

Mykola Kucheriavenko - Doctor of Juridical Science, Professor, Academician of the National Academy of Legal Sciences of Ukraine (Yaroslav Mudryi National Law University, Ukraine);

Vasyl Lemak - Doctor of Juridical Science, Professor, Corresponding Member of the National Academy of Legal Sciences of Ukraine (The Constitutional Court of Ukraine, Ukraine);

Sergii Maksymov - Doctor of Juridical Science, Professor, Corresponding Member of the National Academy of Legal Sciences of Ukraine (Yaroslav Mudryi National Law University, Ukraine);

Olena Orliuk - Doctor of Juridical Science, Professor, Academician of the National Academy of Legal Sciences Of Ukraine (Scientific and Research Institute of Intellectual Property of the National Academy of Legal Sciences of Ukraine, Ukraine);

Mykola Panov - Doctor of Juridical Science, Professor, Academician of the National Academy of Legal Sciences of Ukraine (Yaroslav Mudryi National Law University, Ukraine);

Volodymyr Pylypchuk - Doctor of Juridical Science, Professor, Corresponding Member of the National Academy of Legal Sciences of Ukraine (Scientific and Research Institute of Informatics and Law) of the National Academy of Legal Sciences of Ukraine, Ukraine);

Sergii Prylypko - Doctor of Juridical Science, Professor, Academician of the National Academy of Legal Sciences of Ukraine (The High Qualification Commission of Judges of Ukraine, Ukraine); 
Petro Rabinovych - Doctor of Juridical Science, Professor, Academician of the National Academy of Legal Sciences of Ukraine (Ivan Franko National University of Lviv, Ukraine);

Viacheslav Rumiantsev - Doctor of Juridical Science, Professor, Corresponding Member of the National Academy of Legal Sciences of Ukraine (Yaroslav Mudryi National Law University, Ukraine);

Oleksandr Sviatotskyi - Doctor of Juridical Science, Professor, Academician of the National Academy of Legal Sciences of Ukraine (Publishing House "Law of Ukraine", Ukraine);

Anatolii Selivanov - Doctor of Juridical Science, Professor, Academician of the National Academy of Legal Sciences of Ukraine (Verkhovna Rada of Ukraine, Ukraine);

Inna Spasybo-Fateieva - Doctor of Juridical Science, Professor, Corresponding Member of the National Academy of Legal Sciences of Ukraine (Yaroslav Mudryi National Law University, Ukraine);

Volodymyr Tykhyi - Doctor of Juridical Science, Professor, Academician of the National Academy of Legal Sciences of Ukraine (The National Academy of Legal Sciences of Ukraine, Ukraine);

Yurii Shemshuchenko - Doctor of Juridical Science, Professor, Academician of the National Academy of Sciences of Ukraine and National Academy of Legal Sciences of Ukraine (V. M. Koretsky Institute of State and Law of the National Academy of Sciences of Ukraine, Ukraine);

Valerii Shepitko - Doctor of Juridical Science, Professor, Academician of the National Academy of Legal Sciences of Ukraine (Yaroslav Mudryi National Law University, Ukraine);

Olga Shylo - Doctor of Juridical Science, Professor, Corresponding Member of the National Academy of Legal Sciences of Ukraine ( Yaroslav Mudryi National Law University, Ukraine);

Mykhailo Shulga - Doctor of Juridical Science, Professor, Corresponding Member of the National Academy of Legal Sciences of Ukraine (Yaroslav Mudryi National Law University, Ukraine)

\section{EDITORIAL BOARD}

Oleksandr Petryshyn - Doctor of Juridical Science, Professor, Academician of the National Academy of Legal Sciences of Ukraine (Chairman of the Editorial Board) (The National Academy of Legal Sciences of Ukraine, Ukraine);

Théo Hassler - Professor (The University of Strasbourg, France);

Flavius Antoniu Baias - Professor (The University of Bucharest, Romania);

Jürgen Basedow - Professor (Max Planck Institute of the foreign and international private law, Germany);

Băieşu Sergiu - Doctor in Law, University Professor (Faculty of law of Moldova State University, Moldova);

William Eliot Butler - Professor (The School of Law, University of Pennsylvania, USA);

Yurii Bytiak - Doctor of Juridical Science, Professor, Academician of the National Academy of Legal Sciences of Ukraine (Yaroslav Mudryi National Law University, Ukraine);

Stanislav Buka - Professor (Baltic International Academy, Latvia);

Yermek Buribayev - Doctor of Juridical Science, Professor (Abai Kazakh National Pedagogical University, Kazakhstan);

Csaba Varga - Professor (The Institute of Legal Studies, Hungarian Academy of Sciences, Hungary);

Anatolii Getman - Doctor of Juridical Science, Professor, Academician of the National Academy of Legal Sciences of Ukraine (Yaroslav Mudryi National Law University, Ukraine);

Yevhen Hetman - Doctor of Juridical Science, Professor (The National Academy of Legal Sciences of Ukraine, Ukraine);

Andriy Hryniak - Doctor of Juridical Science, Professor (Scientific and Research Institute of Private Law and Entrepreneurship named after Academician F. G. Burchak of the National Academy of Legal Sciences of Ukraine, Ukraine);

Konstiantyn Gusarov - Doctor of Juridical Science, Professor (Yaroslav Mudryi National Law University, Ukraine); 
Nataliia Gutorova - Doctor of Juridical Science, Professor (Poltava Law Institute of the Yaroslav Mudryi National Law University, Ukraine);

Tomas Davulis - Professor (Vilnius State University, Lithuania);

Tomasz Giaro - Professor (Warsaw University, Poland);

Mykola Inshyn - Doctor of Juridical Science, Professor, Academician of the National Academy of Legal Sciences of Ukraine (Taras Shevchenko National University of Kyiv, Ukraine);

Farkhad Karagussov - Doctor of Juridical Science, Professor (The Institute of private law of Caspian university, Republic of Kazakhstan);

Emanuel Castellarin - Professor (The University of Strasbourg, France);

Karl Hermann Kästner - Professor (The Universit of Tübingen, Germany);

Rolf Knieper - Professor (Coethe University Frankfurt, Germany);

Tanel Kerikmäe - Professor (The School of Law, Tallinn Technical University, Estonia);

Zhanna Khamzina - Doctor of Juridical Science, Professor (Abai Kazakh National Pedagogical University, Kazakhstan);

Anatoliy Kostruba - Doctor of Juridical Science, Professor (Vasyl Stefanyk Precarpathian National University, Ukraine);

Alexey Kot - Doctor of Juridical Science, Senior Research Associate (Scientific and Research Institute of Private Law and Entrepreneurship named after Academician F. G. Burchak of the National Academy of Legal Sciences of Ukraine, Ukraine);

Nataliia Kuznietsova - Doctor of Juridical Science, professor, Academician of the National Academy of Legal Sciences of Ukraine (Taras Shevchenko National University of Kyiv, Ukraine);

Rainer Kulms - Professor (Max Planck Institute of the foreign and international private law, Germany);

Yoshiike Kurumisawa - Professor (The School of Law, Waseda University, Japan);

Iryna Lukach - Doctor of Juridical Science, Professor (Taras Shevchenko National University of Kyiv, Ukraine);

Snieguolè Matulienė - Professor (The University of Mykolas Romeris, Lithuania);

Catherine Maia - Professor (The University of Lisbon, Portugal);

Vasyl Nastyuk - Doctor of Juridical Science, Professor, Corresponding Member of the National Academy of Legal Sciences of Ukraine (Yaroslav Mudryi National Law University, Ukraine);

Konrad Osajda - Ph. D. (The University of Warsaw, Poland);

Mariana Pleniuk - Doctor of Juridical Science, Professor (Scientific and Research Institute of Private Law and Entrepreneurship named after Academician F. G. Burchak of the National Academy of Legal Sciences of Ukraine, Ukraine);

Svitlana Serohina - Doctor of Juridical Science, Professor, Corresponding Member of the National Academy of Sciences of Ukraine (Scientific and Research Institute of State Building and Local Government of the National Academy of Legal Sciences of Ukraine, Ukraine);

Isabela Skomerska-Mukhovska - Professor (The University of Lodz, Poland);

Kyrylo Tomashevskyi - Doctor of Juridical Science, Associate Professor (Educational establishment of the Federation of Trade Unions of Belarus "International University "MITSO", Republic of Belarus);

Viktor Shevchuk - Doctor of Juridical Science, Professor (Yaroslav Mudryi National Law University, Ukraine);

Hans Joachim Schramm - Professor (The Institute of Eastern Law of the University of Technology, Business and Design, Germany);

Ivan Yakoviyk - Doctor of Juridical Science, Professor (Yaroslav Mudryi National Law University, Ukraine);

Oleg Yaroshenko - Doctor of Juridical Science, Professor, Corresponding Member of the National Academy of Legal Sciences of Ukraine (Yaroslav Mudryi National Law University, Ukraine) 


\section{3мict}

\section{CTATTI}

МУЗА О. В.

Судова правотворчість та адміністративні правовідносини:

пошук взаємозв'язку

КУЧЕРЯВЕНКО М. П., СМИЧОК Є. М.

Момент виконання обов'язку зі сплати податків та зборів:

податково-правовий аспект

КНІППЕР Р., БІРЮКОВ О. М.

Територіальні громади у цивільно-правових відносинах

КОБАН О. Г.

Завдання внутрішньої державної діяльності в процесі соціалізації.

КОСТЕНКО А. О.

Інтернет-лібертаріанство та інтернет-етатизм в контексті інтернет-прав людини

ВАРИЧ О. Г.

Рівність, свобода, справедливість: ціннісно-правові властивості 76

ГРИЩУК В. К.

Ефективність кримінально-правового забезпечення охорони

і захисту гідності в Україні: питання соціальної зумовленості

КЕРІКМАЕ Т., ЖУРАВЕЛЬ В. А.

Окремі криміналістичні вчення: концептуальні підходи до формування. 98

ЗІНЧЕНКО О. В.

Особливості статусу президента в арабських республіках

(порівняльний аналіз)

ШРАММ Х. І., КОСТРУБА А. В.

Правова класифікація видів інформації про фізичну особу

РОЖНОВА В. В.

Докази і доказування: про тенденції удосконалення кримінального процесуального закону

ТУГАРОВА О. К.

Логічна природа непрямих доказів у кримінальному процесі.

ТОЛОЧКО О. М.

Стандарти доказування у кримінальному провадженні

(порівняльний аналіз)

\section{ОГЛЯДОВІ СТАТТІ}

БАТЛЕР В., СРМОЛАСВ В. М.

На шляху до соборності України (до 100-річчя Акта злуки УНР із ЗУНР). 166 


\section{Table of contents}

\section{ARTICLES}

MUZA O. V.

Judicial Legislation and Administrative Legal Relations:

Search of Interconnection.

KUCHERYAVENKO M. P., SMYCHOK YE. M.

Moment of Execution of the Duty to Pay Taxes and Fees: a Tax-Legal Aspect 25

KNIEPER R., BIRYUKOV A. N.

Territorial Communities in Civil Legal Relations.... 36

KOBAN O. G.

Task of Internal State Activity in the Socialisation Process. 48

KOSTENKO A. A.

Internet-Libertarianism and Internet-Etatism in the Context

of the Internet Rights of a Person. 62

VARYCH O. G.

Equality, Freedom and Justice: Value-Legal Properties HRYSHCHUK V. K.

Protection and Security in Ukraine: Questions of Social Conditionality

KERIKMÄE T., ZHURAVEL V. A.

Private Criminalistics Doctrines: Conceptual Approaches to the Formation 98

ZINCHENKO O. V.

Features of the President Status in the Arab Republics (Comparative Analysis). 110

SCHRAMM H. J., KOSTRUBA A. V.

Legal Classification of Types of Information About an Individual. ROZHNOVA V. V.

Evidence and Proof: Trends in the Imporvment Orf the Criminal Procedural Law TUGAROVA O. K.

The Logical Nature of Indirect Evidence in Criminal Procedure 141

TOLOCHKO O. M.

Stadards of Proof in Criminal Procedure (Comparative Analysis) 153

\section{REVIEW ARTICLES}

BUTLER W. E., YERMOLAIEV V. M.

Towards the Course of Ukraine (to the 100th Anniversary of the Act of Unification of the Upr with Zunr) 166 
УДК 347.931:342.92

DOI: 10.31359/1993-0909-2019-26-1-13

Олег Валентинович Муза
Кафедра кримінального та адміністративного права
Академія адвокатури України
Київ, Україна

СУДОВА ПРАВОТВОРЧІСТЬ ТА АДМІНІСТРАТИВНІ ПРАВОВІДНОСИНИ: ПОШУК ВЗАЕМОЗВ'ЯЗКУ

Анотація. Стаття присвячена дослідженню впливу рішень органів судової влади на процес застосування норм адміністративного законодавства. Автором підкреслено важливість визначення новітньої системи джерел адміністративного права з метою формулювання ролі судових рішень для динаміки адміністративних правовідносин. Проаналізовано співвідношення понять «правозастосування», «судове рішення» та «судова правотворчість». Встановлено, щуо складність взаємозв'язку між судовою правотворчістю та адміністративними правовідносинами полягає в особливому впливі актів органів судової влади на функціонування публічної адміністрації. Визначено, щзо правова природа публічно-правового спору торкається публічного порядку в державі, необхідності пропориійного співвідношення публічних і приватних інтересів, функиіонування органів публічної адміністрації тощо. Встановлено, щзо ефективність зв'язку між судовою правотворчістю та адміністративними правовідносинами залежить від такого явища як судова помилка, оскільки за таких умов відповідний вплив може мати деструктивний характер на сферу публічного управління. Реформа процесуального законодавства 2017-2019 років запроваджує поєднання ознак континентального та загального права. Результатом изього є зміна розуміння судового рішення як джерела права, тобто судове рішення може містити положення, що мають обов'язковий характер для учасників адміністративно-правових відносин. У сучасному адміністративному праві ще не існує сформованих підходів, які б мали єдино правильне вирішення питання реалізації судових рішень у сфері застосування адміністративного законодавства, розвитку адміністративних правовідносин, збалансованого поєднання впливу виконавчої та судової гілок влади на сфери публічного управління. У цьому ракурсі, засобами судової правотворчості суд повинен стати незалежним арбітром для вирішення проблем поточного застосування адміністративного законодавства.

Ключові слова: судова правотворчість, адміністративні правовідносини, публічна адміністрація, судове рішення, адміністративні суди. 
Oleh V. Muza

Department of Criminal and Administrative Law Academy of Advocacy of Ukraine

Kyiv, Ukraine

\title{
JUDICIAL LEGISLATION AND ADMINISTRATIVE LEGAL RELATIONS: SEARCH OF INTERCONNECTION
}

\begin{abstract}
The article is dedicated to research of the impact of the court decisions on the process of applying the norms of administrative legislation. The author emphasised the importance of determining the newest system of administrative law sources with the aim to formulate the role of court decisions for the dynamics of administrative-legal relations. It is analysed the correlation of such concepts as "law enforcement", "court decision" and "judicial legislation". It is established that complexity of the interconnection between judicial legislation and administrative-legal relations consists in the special impact of the acts of judicial bodies on the public administration functioning. The legal nature of public dispute touches upon the public order in the state, the necessity for proportional correlation of public and private interests, public administration functioning, etc. It is concluded that the efficiency of connection between judicial legislation and administrative legal relations depends on such a phenomenon as a judicial error since under such conditions the relevant impact can have a destructive nature regarding the field of public administration.
\end{abstract}

Key words: judicial legislation, administrative legal relations, public administration, court decision, administrative courts.

\section{INTRODUCTION}

Modern legal practice of Ukraine is characterised by the appearance and spread of intersectoral relations in the legal regulation mechanism of social relations. The classical understanding of the branch of law is supplemented by the necessity to distinguish the latter from the branch of legislation and individual sub-branches of law that leads to the allocation of independent groups of legal relations. One of the factors which has an impact on the interdisciplinary nature of the legal system is the judicial practice which by means of certain procedural forms and means solves the complex current matters of evaluating the problems of development of sectoral legal relations, providing with the help of judicial decisions the evaluation of legal regulation state of homogeneous legal relations. Given this fact, in legal science doctrinal views on judicial practice as a source of law and a factor of necessity to improve sectoral legislation are changing.

The development of administrative law in Ukraine is characterised by a change of theoretical views on the nature and types of administrative relations: reconsideration of general theory of administrative law; slow but gradual administrative law reforming; introduction and development of administrative court procedure; appearance of certain branches of legislation which conceptual origins are based on the subject of administrative law and the like. However, the greatest feature that determines the public powermanagerial relations is the impact of judicial practice due to which a particular type of 
administrative legal relations along with obligatory legal regulation experiences legal changes. It is the beginning of administrative courts functioning in the 2000s that ensured the self-sufficient division of administrative legal relations into material and procedural within the framework of a single subject of administrative law, appeared new opportunities for improvement of the legal regulation mechanisms of the latter, appeared the ability to put into practice the requirements of humanocentrism principle in public administration and protect the rights, freedoms and interests of individuals from possible illegal public power-managerial impact (infringement).

Judicial decisions are not only legal acts by which the court on behalf of the state decides the question of the scope of rights of the parties to the disputed legal relations, but also in their legal positions it is possible to find a continuation of the administrative legal theory. Judicial interpretation of administrative and material norms of law eventually affects the legislative improvement of administrative and legal regulation of social relations.

At the present stage of legal science development, the problems of judicial lawmaking are investigated by V. V. Komarov [1], L. M. Moskvich [2], S. V. Prylutskyi [3], A. O. Selivanov [4], S. V. Shevchuk [5] and the others. It is the idea of creating judicial law in Ukraine that makes it necessary to analyse the interconnection between judicial and extrajudicial instruments of impact on the development of legal relations.

S. V. Shevchuk notes that "judicial practice plays a role of concretisation of laws and in this it complements the legislator, or rather it becomes a source of law in case of a legislator's "inaction" when the normative legal acts contain gaps, their textual presentation is ambiguous and contradictory for understanding as well as raises problems in law enforcement. Judicial practice fills the gaps by using the analogy of right and law, that is, the result of this analogy and the order of judicial motivation has a special weight and importance for the subsequent resolution of similar cases. Of course, a legislator can consolidate the results of judicial practice by legislative concretisation. But this can take place already post-factum, at the time when the interests of justice require the specification of laws through judicial practice in the process of hearing a particular case" [5].

A. O. Selivanov emphasizes that "the doctrinal concept of judicial law can not yet be considered an internally completed $<\ldots>$ judicial law is one of the branches of public law in which its main subject is judiciary power which functions independently on the constitutional principle of separation of powers, and the existence of constitutional, civil, administrative and other types of legal proceedings are the forms of the state activity (justice implementation)" [4].

T. O. Kolomoyets notes that "in the scientific community, the thesis of the expediency of so-called judicial law which would "absorb" all the procedural judicial components of the elements of the domestic legal system, is increasingly substantiated that, in its turn, would contribute to ceasing any further discussions regarding the understand- 
ing of the process content (as general concepts) and its variations and distinguish it from other legal institutions" [6].

N. Ye. Blazhivska notes that "the judicial doctrine, first of all, is intended to fill gaps in the legislation and demonstrate the directions for its improvement, and also supports the understanding of the concept of judicial doctrine as the ratio of the ideological load of the doctrine with the choice of a reasonable response to a reasonable argument in the process of applying the norms of the law in the court" [7].

The Law of Ukraine On Amendments to the Economic Procedural Code of Ukraine, Civil Procedural Code of Ukraine, Code of administrative procedure of Ukraine and other legislative acts of 03.10.17. No. 2147-VIII (hereinafter referred to as Law No. 2147-VIII) [8] the Code of Administrative Procedure of Ukraine (hereinafter - the CAP of Ukraine) [9] is set out in a new version and came into force on December 15th, 2017 together with the beginning of the Supreme Court's functionning. It is the latest provisions of the procedural legislation that establish the necessity for the search of the interconnection between decisions of administrative courts and administrative legal relations with the purpose of harmonisation of their legal regulation.

\section{MATERIALS AND METHODS}

The scientific methodology is based on the use of general theoretical research methods: with the help of the method of analysis, the study of the legal significance of judicial practice and judicial lawmaking for the regulation of administrative legal relations was conducted; the system method allowed to draw conclusions about the place and role of court decisions in the system of administrative law sources; obtaining the results of scientific research became possible with the help of formal-legal and logical-legal methods which made it possible to come to the conclusion about the interconnection between public-managerial and judicial activities; the use of the terminological approach provided an analysis of the interconnection between the concepts of "law enforcement", "judgment" and "judicial lawmaking".

An important role in conducting the research was played by the comparative- legal method, with the help of which it was possible to find differences in understanding the essence of the judgment as a source of law in the continental and Anglo-Saxon legal systems. It is this approach that ensured the development of proposals for determining the place of judicial practice in the field of public-managerial legal relations and the necessity to achieve effective interaction between the bodies of executive and judiciary power. The comparative legal method of research also made it possible to analyse different various sources of theoretical understanding of the purpose and role of law in the regulation of social relations. This made it possible to develop author's statements about the role of the type of legal understanding in order to justify the importance of judicial decisions for the sphere of executive power and administrative legal relations.

One should note that when conducting the study of the interconnection between 
judicial lawmaking and administrative legal relations, there was a necessity to analyse scientific sources not only on administrative law, but also on theory of law (general theoretical law), theory of legal process and constitutional law and judicial law. Also, one should note the state of scientific research in the field of administrative law has no high degree of coverage of impact of the judicial bodies on the sphere of public-administrative relations.

The article provides an overview of the regulatory provisions of the administrative procedural law after a procedural law reform was passed in 2017.

\section{RESULTS AND DISCUSSION}

\subsection{Judicial decisions in the system of administrative law sources}

For a long time coverage of the issue of administrative law sources in administrativelegal science has been based on the principle of using the achievements of general theoretical law, taking into account the specific features that determine the sources of law in the field of administrative and legal relations. During a rather long transition from the Soviet legal understanding to modern approaches in legal science, scientists considered the issue of administrative law sources which are based on the approaches of the continental system of law. However, the problem of system and determination of the right sources since the early 2000s, the processes that started in the national law system have been exacerbated and especially activated after the legal registration of the Association of Ukraine with the European Union.

In General Theory of Law Textbook edited by M. I. Koziubra there is a definition of "type of legal understanding" in which it is noted that the fundamentally important theoretical category which reflects the possibilities of simultaneous application of systemic, functional, synergetic and hermeneutic approaches in the implementation of the characteristics of law. According to the authors of the textbook, the typology of legal understanding is based on the legal and ideological criterion (depending on what is output in understanding of law-superpower-natural, state or real-life) that that made it possible to distinguish such types as natural law, legal-positivist and sociological. Within the framework of the legal-positivist type, any creative role of a judge is denied, reducing him exceptionally to the "voice of law", that is, formally-dogmatic application. However, the sociological type of legal understanding on the contrary increases the role of the court not so much as the "voice of the law", but as an instrument of lawmaking [10]. That is why the type of legal understanding directly affects the formation of scientific knowledge about the sources of law, their system and purpose.

In academic course of Administrative Law of Ukraine edited by V. B. Averianov, the sources of administrative law include laws, resolutions of the Verkhovna Rada of Ukraine, decrees of the President of Ukraine, acts of the Cabinet of Ministers of Ukraine, orders of ministries, central executive authorities,normative legal acts of the Verk- 
hovna Rada and the Council of Ministers of the Autonomic Republic of the Crimea, acts of local state administrations, decisions of local councils (local self-government bodies), acts of governing bodies of state enterprises, institutions, organizations, international agreements (treaties) and international legal acts ratified by the Verkhovna Rada of Ukraine [11]. That is, the classical system of sources of law is given, taking into account the administrative nature of administrative and legal relations. Separately, the textbook presents the thesis of judicial precedents as a source of law and it is stated that the latter can not be recognized as a source of law in the legal system of Ukraine, except for the decisions of the Constitutional Court of Ukraine which "have binding force in the resolution of an unlimited number of individual disputes, that is, have a normative character" [11].

The reference to the phrase "normative character" indicates the possibility of giving the judicial authority the function of norm-setting that is still perceived by the domestic legal science quite critically. Thus, in the system of public power, the legislative function belongs to the Parliament and there is no antithesis, however, if to proceed from the general concept of lawmaking and the appointment of public power, it is unlikely that it can be argued about the "exceptionality" of Parliament as a state institution that develops rules, forms and means of regulating social relations. So, along with this, there do not exist any legal axioms regarding the impossibility of a judicial authority to be a subject of law-making.

Although judicial activity in the framework of lawmaking is limited to procedural norms, however, in the result of this activity, a legal phenomenon appears as a judicial practice in its various forms and dimensions that does not deprive the court decision of being a source of law. M. I. Smokovych notes that "when resolving cases, the court reveals the content of the principles of justice, reasonableness and good faith with the help of the laws of logic and taking into account the content of disputed legal relations. That is, when formulating the criteria on the basis of which the case will be resolved, the court is guided by solely legal arguments, without resorting to considerations of political expediency. Thus, unlike the activities of Parliament, judicial lawmaking is not a political activity" [12].

The authors of General Administrative Law Textbook P. S. Melnyk and V. M. Bevzenko changed classic views on the well-established theory of administrative law of Ukraine, among the sources of administrative law there were called judicial decisions. According to the professors,"...courts and judges are often faced with gaps in the law, the inconsistency of certain provisions of legal acts, that, as a consequence, complicates the implementation of justice. Given this, there is a necessity for judges to develop certain principles (provisions) aimed at eliminating shortcomings that can be found in the existing regulations. Similar principles (provisions) can be applied by other courts (judges) in resolving analogical cases. $<\ldots>$ At the same time, the court (judge) can only specify or supplement legal acts by its(his) decision" [13].

From the given educational and scientific material it should be noted that judicial 
decisions as sources of administrative law should not be understood as all judicial decisions that can be taken or adopted by the judicial authorities, but only the decision of the Constitutional Court of Ukraine, the Supreme Court and the European Court of Human Rights. At the same time, court decisions should be divided into decisions of national courts and international judicial bodies since their legal nature, particuliarities of applying and execution are different.

\subsection{Novelties of the administrative procedural law in the context of judicial lawmaking}

The appearance of the concept of judicial lawmaking should be associated with the search of the existing theoretical and applied connection between lawmaking and justice. The legislative process can never fully overcome existing gaps in law. Besides, there arise gaps in legislation during the process of implementing legislative regulations. That is why the courts, along with a legislator, play an important role in filling the relevant gaps and contribute to the solution of controversial issues in law enforcement.

Taking into account the necessity to expand the powers of the court in solving the current problems of law enforcement, the administrative procedural law was updated on October 3rd, 2017. We consider it necessary to cite the following provisions of the Code of Administrative Procedure of Ukraine which increase the importance of judicial decisions as sources of administrative law and the application of administrative law:

1) the introduction of typical and exemplary administrative cases, i.e. the creation of the basis for combining the continental law system with the common law system that makes it possible to apply judicial precedents by all national courts;

2) the possibility of the court to terminate the application of the law or other legal act. If the court comes to the conclusion that such a law or other legal act is contrary to the Constitution (para. 1 Part 4 Art. 7 of the Code of Administrative Procedure of Ukraine), it changes the established traditions of normativism about the role of the law in the regulation of public relations and gives the court the right not to be limited by the norms of legislative or even other legal acts;

3) procedural regulation of the procedure for derogating from the conclusion on the application of the rule of law in similar legal relations set out in the earlier approved decision of the Supreme Court (Art. 346 of the Code of Administrative Procedure of Ukraine) - ensures an evolutionary way of substantive and procedural law application by the Supreme Court.

In the result of the reform of the procedural legislation of Ukraine, there appeared a provision that changes management practice and makes it conditional by the court decision. It comes to provisions of the Law of Ukraine On Public Service [14] which stipulates the elements of the disciplinary offense of a public servant - a decision that contradicts the conclusions on applying the relevant rule of law set out in the decision of the Supreme Court in respect of which the court issued a separate decision (para.15 Part 1 Art. 65 of this Law). 


\subsection{Role of judicial decisions in solving administrative law problems}

The question arises on how much Law No. 2147-VIII adopted by the Parliament changes the existing scientific views on the role of judicial decisions in solving problems of administrative law? It is important to cite the provisions of Part 5 Art. 346 the Code of Administrative Procedure of Ukraine which stipulates the right of the court to consider the case in a collegium or chamber, in cassation and refer the case to the Grand Chamber of the Supreme Court. If the court comes to the conclusion that the case contains an exceptionally legal problem, then its referring is necessary for ensuring the development of law and the formation of a unified law enforcement practice. It is this procedural rule that provides a possibility to the court to use a lawmaking function to solve the problems of administrative law. An answer to this question also lies in the framework of scientific and practical connection of the concepts of "law enforcement", "court decision" and "judicial lawmaking".

Law enforcement as a separate independent form of right implementation reflects the content and essence of legal regulation of a certain type of social relations. That is obligatory participation of government authorities in the enforcement process that makes such an activity of legal character an important component of efficiency evaluation of applying the norms of administrative-procedural legislation.

The legal nature of the legal positions of the supreme judicial bodies, contained in the relevant judicial decisions, has a double character. If to take into account the national legal system's belonging to the system of continental law, the judicial conclusions set out regarding the particularities of the interpretation and applying of the relevant provisions of legal acts have an advisory character. If to proceed from the procedural legislation provisions, the legal conclusions of the Supreme Court are obligatory in respect of applying both judicial practice and management practice of the power subjects. "The lawmaking activity of the higher courts of general jurisdiction is carried out at the stage of cassation reconsideration of court cases. At this stage of court procedure, the sequence of lawmaking actions of the higher courts consists in revealing the gaps in legal regulation, their filling and taking a decision on the case and its official promulgation. These lawmaking actions are united by the purpose of establishment of normative-legal prescriptions set out in precedential lawmaking acts" [15]. "In the normative-legal acts of judicial power (in the form of norms clarification or establishment of generally obligatory procedural rules), the rules of law are not the result of the decision of a particular case, but the consequence of the purposeful lawmaking activity of supreme judicial bodies. A characteristic feature of these rules is that their formulation is carried out either on the basis of the generalisation of the practice of resolving a certain category of disputes or they represent procedural rules for the consideration of disputes, the powers regarding their establishment are stipulated by the law by supreme judicial authorities" [16].

The acts of judicial lawmaking can have different legal nature and are divided into 
lawmaking acts, interpretative acts, law enforcement acts and organisational-judicial acts.

The normative character of court decisions defines the concept of "judicial lawmaking". A. Steinman distinguishes between the concepts of "lawmaking" and "judicial legislation", noting that judicial legislation should take place within the constitutional powers of the judiciary and reflect the interpretation of constitutional rules and regulations as well as take into account the rules of stare decisis doctrine which obliges lower courts to take into account the judicial reasoning of the Supreme Court [17]. A similar position on the support of judicial legislation expresses M. I. Koziubra who notes that "one of the main reasons for the necessity for judicial legislation is the need to specify the rules of laws and other regulations adopted by the official subjects of law - making or to be exact, their updating, namely, adaptation to specific situations which is the subject of the court's consideration..." [18].

Law enforcement as a result of the appearance of court decisions in which can be traced the elements of legislation (the appearance of legal rules for the regulation of social relations different from those enshrined in legal acts) remains a key category for characteristics of the court decision as a source of law. This can be justified by such a theoretical construction as ratio decidendi - "a court decision by itself has no special meaning, in it obligatory aspects are the norm and principle it is based on and the proof of which it serves. That is, the norm which is directly or indirectly interpreted by the judge" [19]. So, one should distinguish between ratio decidendi and obiter dicta ("said among other things") since the latter is not a part of ratio decidendi and reflects the individual views of the court on the subject of discussion.

Given that the legal system of Ukraine belongs to the system of continental law, one should note the existence of the jurisprudence constant doctrine, that is, the established judicial practice. What does this mean in the context of our research? Judicial practice can be called "established" if it has been formed for a long time and in the formation of such a judicial practice the courts of lower instances play a role because they consider a number of court cases. And it also gives grounds to claim that legal conclusions of the Supreme Court appear not only on the basis of consideration of a certain precedent, but also as a result of reconsideration of decisions of local and appellate courts.

\subsection{Search of interconnection between judicial lawmaking and administrative legal relations}

The complexity of the interconnection between judicial legislation and administrative legal relations lies in the special impact of acts of the judiciary on the public administration functioning. The court, determining the features of applying substantive law should take into account the powers of the authority subject and be guided by the provision of Part 2 Art. 19 of the Constitution of Ukraine. The legal nature of a public-law dispute touches upon public order in the state, the necessity for a pro- 
portional balance between public and private interests, the functioning of a public administration body and the like. Therefore, the procedural possibilities of the court in solving the problems of law do not give it grounds to go beyond the obligatory prescriptions of organising the public administration in the state. This is one of the main features of administrative court procedure, the court can only solve specific legal problems on the example of a specific public-legal dispute, but it can not directly interfere in public power-managerial activity. Therefore, in the interconnection between judicial legislation and administrative legal relations there are boundaries conditioned by the particularities of the state power organising.

In view the above said, one should agree with the position of R. Kremton who, studying the matter of interconnection between judicial legislation and administration, emphasises that the most optimal form of such an interconnection is a model of judicial control which stipulates external verification of the activity of executive agencies, government bodies for its compliance with legal acts. However, in his opinion, the traditional court decision which is based on the analysis of specific legal facts, does not oblige public servants to take positive measures in the future in order to avoid new legal actions. R. Kremton suggests to the court to act as a public administration, complementing in its decisions the possibility of extension of administrative impact to resolve specific controversial situations [20].

In this context, A. Lehevi calls the court a "state actor" that by his decisions solves a number of matters of constitutional rights and freedoms, property, public formations, etc. The constitutional provisions on the power separation do not necessarily indicate the practical ways in which the judiciary participate in the exercise of powers held by other branches of government [21].

Given this, there are controversial matters: 1) does the court, using the possibilities of judicial legislation, solving specific cases and making decisions, determine/reconsider/change the procedure for the implementation of rights, freedoms and interests of individuals in the field of public administration? 2) is the role of the main actor in the field of public administration - the body of public administration - supplemented by the judicial authority thanks to the acts of judicial legislation? The matter is quite polemic, however, this time one should recall the principle of unity of state power and the constitutional boundaries of judicial intervention in the activities of the legislative and executive branches of power.

\section{CONCLUSIONS}

The matter of the judicial practice importance is actual for the domestic legal science, as it is a system-forming factor for the deepening the general theory of legal process and the possible formation of judicial law. The Ukrainian legal opinion made a way from categorical denial of judicial legislation to recognition of decisions of the supreme judicial bodies as sources of law. The reform of procedural legislation on October 3rd, 2017 introduces a combination of features of continental and common 
law. The result of this is a change of understanding the court decision as a source of law, that is, the court decision can contain provisions that are obligatory for participants of administrative-legal relations.

In modern administrative law there do not exist yet formed approaches which would have a correct solution of the matter of court decisions implementation in applying an administrative law, development of administrative legal relations, balanced combination of the impact of executive and judicial branches of power on the public administration field. In this perspective, by means of judicial legislation, the court should become an independent arbitrator to solve the problems of the current applying the administrative law. It is in the acts of judicial that the problematic matters of relations between individuals and public administration can be solved, however, for this it is necessary to develop high-quality judicial practice in different categories of public-law disputes in terms of new procedural legislation and determine additional conditions for the legality of the administrative-legal impact of the authority subjects on individuals in administrative-legal relations in the decisions of the Grand Chamber of the Supreme Court, the Cassation Administrative Court of the Supreme Court. So, the effectiveness of the connection between judicial legislation and administrative legal relations also depends on the phenomenon of judicial error, since under such conditions the relevant impact can have a destructive nature on the field of public administration.

\section{REFERENCES}

[1] Komarov, V. (2011). Civil Proceedings in the Global Context. Law of Ukraine, 10, 22-44.

[2] Moskvych, L. M. (2012). Improvement of the Judicial Procedure as a Component of the Efficiency of the Court's Functioning. Bulletin of Supreme Court of Ukraine, 3, 22-29.

[3] Prylutckiy, S. V. (2012). Introduction to the Theory of the Judiciary (Society, Justice, State). Kyiv: Institute of State and Law named after V. M. Koretsky.

[4] Selivanov, A. O. (2015). Judicial Law as Independence Subject of System of Ukrainian Law. Law of Ukraine, 3, 9-17.

[5] Shevchuk, S. (2010). Judicial Lawmaking: the World Experience and Perspectives in Ukraine. Kyiv: Referat.

[6] Kolomoyetc, T. (2012). Definition of the Concept of «Administrative Process» - the Condition of the Efficiency of Normative and Law Enforcement (Including Judicial) Activities. Word of National School of Judges of Ukraine, 1 (1), 153-160.

[7] Blazhivska, N. (2014). Genesis of Tax Law Doctrine in Judicial Practice of the USA. Bulletin of Higher Administrative Court of Ukraine, 2, 21-31.

[8] The Law of Ukraine "On Amendments to the Commercial Procedural Code of Ukraine, the Civil Procedural Code of Ukraine, the Code of Administrative Legal Proceedings of Ukraine and other legislative acts" of 10.10.17, No. 2147-VIII. Retrieved from http://zakon.rada.gov.ua/laws/show/2147-19/print

[9] The Code of Administrative Legal Proceedings of Ukraine of 03.10.17, No. 2147-VIII. Retrieved from http://zakon.rada.gov.ua/laws/show/2747-15/print

[10] Kozyubra, M. I. (2015). General Theory of Law. Kyiv: Vaite.

[11] Averyanov, V. B. Administrative Law of Ukraine. Academic Course. Kyiv: Yurydychna Dumka, Ukraine. 
[12] Smokovych, M. (2016). The Limits of the Powers of the Court in the Judicial Interpretation Process. Bulletin of Higher Administrative Court of Ukraine, 4, 3-11.

[13] Melnyk, R. S., \& Bevzenko, V. M. (2014). General Administrative Law. Kyiv: Vaite.

[14] The Law of Ukraine "On State Service" of 10.12.15, No 889-VIII. Retrieved from http://zakon.rada.gov.ua/laws/show/889-19/print

[15] Stecyk, N. V. (2010). Judicial Lawmaking: the General Theoretic Concept. Academy of Advocacy of Ukraine Notes, 3, 3-9.

[16] Malyshev, B. (2017). Judicial Lawmaking in the Context of Judicial Reform in Ukraine. Law of Ukraine, 6, 34-38.

[17] Steinman, A. N. (2004). A Constitution for Judicial Lawmaking. University of Pittsburgh Law Review, 65, 556-564.

[18] Kozyubra, M. (2016). Judicial Lawmaking: Anomaly or Immanent Property of Justice. Law of Ukraine, 10, 38-48.

[19] Kross, R. (1985). The Precedent in English Law (translation). Moscow: Yuridicheskaya literatura.

[20] Cramton, R. C. (1976). Judicial Law Making and Administration. Cornell Law Faculty Publications, 988, 551-555.

[21] Lehavi, A. (2011). Judicial Review and Judicial Lawmaking. Minnesota Law Review, 96, $520-583$.

\section{Oleh V. Muza}

Doctor of Legal Sciences, Senior Researcher, Professor

Department of Criminal and Administrative Law

Academy of Advocacy of Ukraine

01032, 27, Taras Shevchenko Blvd., Kyiv, Ukraine

Suggested Citation: Muza, O. V. (2019). Judicial legislation and administrative legal relations: search of interconnection. Journal of the National Academy of Legal Sciences of Ukraine, 26 (1), 13-24.

Submitted: 25/01/2019

Revised: 04/03/2019

Accepted: 28/03/2019 


\title{
УДК 347
}

DOI: 10.31359/1993-0909-2019-26-1-25

Микола Петрович Кучерявенко

Наиіональна академія правових наук України Харків, Україна

\section{$\boldsymbol{\epsilon}_{\text {вген Михайлович Смичок }}$}

Кафедра фінансового права Національний юридичний університет імені Ярослава Мудрого Харків, Україна

\section{МОМЕНТ ВИКОНАННЯ ОБОВ'ЯЗКУ ЗІ СПЛАТИ ПОДАТКІВ ТА ЗБОРІВ: ПОДАТКОВО-ПРАВОВИЙ АСПЕКТ}

\begin{abstract}
Анотація. Процедуру виконання податкового обов'язку пов'язують з особливостями регулювання бюджетних відносин. Формування за рахунок податкових надходжень коштів, щуо забезпечують реалізацію державних функиій, підносить податкові правовідносини до рангу одних з найбільш значущзи для існування держави та тих, щзо вимагають безумовного державного регулювання. Тому основна мета роботи полягає у аналізі зобов'язань щодо сплати податків та зборів з огляду податково-правового аспекту. Сфера дії бюджетного законодавства пов'язується, перш за все, із стадіями бюджетного процесу, процедурами появи, виконання та звітності актів про бюджет. Встановлено, щуо бюджетне та податкове законодавство відрізняються у питаннях оцінки суб 'єктного складу. Держава, надаючи банку лічензію на здійснення банківських операцій, в тому числі і перерахування податків до доходних частин бюджетів, фактично переконує платника в тому, що банк є саме тим суб' сктом, через якого платник не лише має можливість, але і обов'язок сплатити податок. 3 огляду на наведене вище, виходячи із системного аналізу статей 1, 3, 4, 5, 16, 38 та 129 Податкового кодексу Украӥни можна прийти до висновку, що виконання податкового обов'язку платником регулюється виключно нормами податкового законодавства до якого неможливо віднести ні Бюджетного кодексу України, ні спеціальні Закони, які регулюють питання обігу грошових коштів. За такої умови податкове законодавство не покладає на платника додаткових обов'язків, або ж застосування санкцій за діяння, які призвели до ненадходження коштів, сплачених ним у якості податків та зборів, з вини інших осіб, зокрема, банків. Так само належне виконання платником податків свого податкового обов'язку (сплата у встановлений законом строк та у повному обсязі), але не надходження циих коштів на єдиний казначейський рахунок з вини банку, не може породжувати виникнення у такого платника податків повторного обов'язку сплати податків, або зборів. Інший підхід правозастосування був би підставою покладення на платника обов'язку зі сплати податків та зборів двічі.
\end{abstract}

Ключові слова: бюджетне законодавство, платник податків, платоспроможність, комерційний банк. 
Mykola P. Kucheryavenko

National Academy of Legal Sciences of Ukraine Kharkov, Ukraine

\title{
Yevhen M. Smychok \\ Department of Financial Law Yaroslav Mudryi National Law University \\ Kharkov, Ukraine
}

\section{MOMENT OF EXECUTION OF THE DUTY TO PAY TAXES AND FEES: A TAX-LEGAL ASPECT}

\begin{abstract}
Formation by tax revenues of funds that ensure the implementation of state functions, brings tax legal relations to the rank of one of the most significant for the existence of the state and those who require unconditional government regulation. Therefore, the main aim of the research work is to analyse the obligations to pay taxes and fees in terms of a tax-legal aspect. The scope of the budget legislation is primarily related to the stages of the budget process, procedures for the appearance, execution and reporting of acts on budget. It is established that budget and tax legislations differ in terms of evaluation of the parties. A state, by granting a bank a licence to carry out banking operations, including transfer of taxes to the revenue parts of budgets, actually, convinces a payer that the bank is the entity through which a payer not only has an opportunity, but also a duty to pay tax.
\end{abstract}

Key words: budget legislation, taxpayers, platform, commercial bank.

\section{INTRODUCTION}

Revealing the fundamentals and particularities of legal regulation of execution of the tax obligations is definitely an actual field of research, in particular, at the stage of reforming the tax legislation of Ukraine. Despite the fact that considerable attention has already been paid to the study of the legal nature of the tax obligation, the necessity for scientific and theoretical development of procedural aspects of its implementation is due to the absence of special domestic studies of tax law theory $[1 ; 2]$. Since the ultimate meaning of tax relations is contained in their implementation, the clarification of the fundamentals and particularities of the execution of tax duties has both theoretical and practical significance.

A comprehensive view on the process of execution of tax duty and paying taxes sometimes leads to common views and conclusions. At the same time, the very procedure for execution of the tax duty is tried to be associated with the parcularities of regulating budgetary relations, that is, the relations connected with the turnover of funds, namely, the regulation of banking activity [3]. It goes without saying that the comprehensiveness of public relations allows to form a complete picture of the movement of a taxpayer's funds to the final recipient, a state-owner or the territorial community (depending on the type of tax or fee and the budget to which it is entirely or partly directed). At the same time, such comprehensiveness of social relations objectively implies 
clarification of the place of each branch of law (or sub-branch or institution) in such a regulation $[4 ; 5 ; 6]$. It is in this sense that we consider it necessary to clearly delineate these two constructions: a) relations on payment of taxes and fees at the time of execution of the tax duty in this regard; b) relations on the movement of funds from taxpayers and fees to the account of their tax liability and their receipt on the relevant treasury accounts of budgets. That is why it is advisable to pay attention to the correlation and regulation measure of budgetary and tax relations, relations on money turnover and execution of tax duty.

For proper execution of the tax duty in terms of the Tax Code, two conditions should coincide: 1) payment of tax amounts in full; 2) payment of the relevant amounts within the period established by tax legislation [7].

The first condition provides for payment of the tax amount by a taxpayer in full. The tax duty from the payment of relevant money sums can constitute the content of the legal relations, that is, to be an element of the tax obligation. The tax amount should be calculated by a payer on the basis of the provisions of the current tax legislation. This coincides to some extent with another aspect of the execution of the tax duty of a payer prior to the tax payment, namely, tax accounting. In this case, a payer has the right to turn to the tax authorities for consulting or explanations of tax legislation, in particular, regarding the calculation of tax amounts, but the state tax service authorities do not have the obligation to calculate a tax amount for a taxpayer [8]. Consequently, the responsibility for its incorrect calculation is always assigned to a payer. The execution of the tax duty in time stipulates paying off tax amounts which are payable no later than the last day of the period which is determined by the legislation in respect of a tax or fee. The beginning of this period is determined by a certain calendar date from which a payer has an obligation to pay tax. According to general rule, making the change of the tax payment term is not allowed either to a payer or the supervisory authority except for the cases specially stipulated by the Tax Code of Ukraine [7].

\section{MATERIALS AND METHODS}

The methodological basis of the research work is a set of general and special methods of scientific knowledge, the use of which allowed to achieve a set goal and ensure the scientific reliability of the results. For comprehensiveness, completeness, objectivity, correctness and consistency of conclusions, these methods were used in the interconnection.

Dialectical method allowed to reveal objective and comprehensive knowledge of legal reality and determination of the essence of the phenomena under study in the unity of their material content and legal form. Structural and functional analysis allowed to take into account such features of the system as integrativity, correlation of the whole and a part, structure and functions and singling out the elements of the tax duty construction as well as the stages of its implementation. The comparative-legal method was used in the analysis of the current domestic and foreign tax legislation that made 
it possible to summarise the scientific concepts of leading scientists in relation to theoretical and practical problems of execution of tax duty [9]. The use of historical-legal method helped clarify the evolution of legal thought about the nature and importance of taxes in the system of budget revenues. Special-legal (formal-dogmatic) method allowed to conduct an informative analysis of the current state of legislative provisions and develop proposals to eliminate the existing theoretical and legal contradictions as well as shortcomings in the legislation.

The methodological basis of the possibility to research a tax duty of a taxpayer as a law implementation process of adoption of the newest forms of interaction between government and taxpayers which essence is partnership and socially useful result was studied by such scholars as D. O. Hetmantsev, A. V. Holovach, P. M. Duravkin, O. V. Larina, D. H. Muliavka, O. V. Onishko, N. Yu. Onishchuk, H. V. Rossikhina, I. L. Samsin, R. V. Stetsko, M. M. Chynchyn, S. V. Shakhov and the others.

\section{RESULTS AND DISCUSSION}

\subsection{Particularities of tax and budget regulation}

When analysing the above problem, very often at the stage of law enforcement, when resolving tax disputes, the courts focus on the fact that the moment of execution of the tax duty should be associated with the receipt of a taxpayer's funds on account of his tax duty to the relevant treasury account $[10 ; 11]$. So, according to para. 5 Art. 45 of the Budget Code of Ukraine, taxes and fees and other incomes of the state budget are recognized credited to the state budget from the date of transfer to the single treasury account - it is difficult to agree with it. When delimiting budgetary and tax relations, it is necessary to consider that according to Art. 9 of the Budgetary Code of Ukraine tax revenues are one of the main sources of the budget incomes formation. But this does not mean that the time of tax payment and collection ends at the time of receipt of taxes and fees to the budget.

First, crucial is the reference to para. 1.1 Art. 1 of the Tax Code of Ukraine according to which this act regulates relations arising in the field of taxes and fees, in particular, it determines a full list of taxes and fees levied in Ukraine, and the procedure for their administration as well as payers of taxes and fees, their rights and obligations, the competence of the supervisory authorities, the powers and duties of their officials during tax administration and liability for the violation of tax legislation. At the same time, Art. 1 of the Budgetary Code of Ukraine determines that it regulates relations arising in the process of preparation, consideration, approval and implementation of budgets, reporting on their implementation and control over compliance with fiscal legislation and issues of responsibility for violation of fiscal legislation as well as the legal principles of formation and repayment of state and local debt. It is demonstrably clear that the scope of the fiscal legislation is primarily associated with the stages of the budget process and the procedures for the appearance, implementation and reporting of budget acts. This does not give grounds to assume that the Budgetary Code of Ukraine at least 
partially regulates the execution of tax duty. It regulates fund revenues to the profitable parts of budgets, but not the relations connected with the transfer of these funds by taxpayers to the authorized entities.

Second, the execution of the tax duty is regulated exceptionally by the tax legislation. On the basis of para. 3.1. Art. 3 Tax Legislation of Ukraine of the Tax Code of Ukraine, tax legislation of Ukraine consists of Constitution of Ukraine; this Code; Customs Code of Ukraine and other laws on customs matters in terms of regulation of legal relations arising in connection with the taxation of transaction fee of displaced goods across the customs border of Ukraine; current international treaties, consent on obligatoriness of which is given by the Verkhovna Rada of Ukraine and which regulate taxation issues; normative- legal acts adopted on the basis of and for the implementation of this Code and laws on customs issues; decisions of the Verkhovna Rada of the Autonomous Republic of the Crimea and local authorities on local taxes and fees adopted under the rules established by this Code. So, the Budgetary Code of Ukraine is not included in the legislation that regulates the execution of tax duties, namely, the tax payment. That is why one may not extend the validity of its rules regarding regulation of the payment of taxes and fees on determining the moment of such a payment [7].

Even if to imagine a situation that the execution of the tax duty regarding transferring funds to the single treasury account should occur in compliance with the norms of the Budgetary Code of Ukraine and the Law of Ukraine On Payment Systems and the Transfer of Funds in Ukraine, there will be an unconditional collision of the norms of these normative legal acts with the norms of the Tax Code of Ukraine (they lay different approaches to determining the moment of payment of taxes and fees). Also, on the basis of para. 4.1.4 Art. 4 of the Tax Code of Ukraine (legality presumption of a payer's decisions) in any case a decision should be made in favour of a taxpayer.

If to speak about the absence of legal regulation of the issue at the level of the Tax Code of Ukraine and characterise it as a gap in the legislation, overcoming this negative legal phenomenon in public areas of law by analogy is not allowed. This follows from the content of Art. 3 and Art. 5 of the Tax Code of Ukraine. Thus, according to para. 5.2. 5 of the Tax Code of Ukraine, if the concepts, terms, rules and provisions of other acts contradict the concepts, terms, rules and provisions of this Code, for regulation of the taxation concepts relations, the terms, rules and provisions of this Code are applied. And the concepts and content of "execution of tax duty" are determined by the norms of the Tax Code of Ukraine. There is also no need to refer to para. 5.3 of article 5 of the Tax Code of Ukraine which establishes the possibility of applying the analogy of the law as a means of overcoming the gaps of tax and legal regulation. First, there is no term that would not have been determined in the tax legislation (payment, transfer, execution of tax obligations - all these categories are determined by the Tax Code of Ukraine). Second, para. 5.3 and 5.2 Art. 5 of the Tax Code of Ukraine contradict each other, thereby creating a collision of norms which in tax and 
legal regulation should be resolved again in favour of a taxpayer (para. 4.1.4 para. 4.1 Art. 4 of the Tax Code of Ukraine) [7].

According to para. 38.1. Art. 38 of the Tax Code of Ukraine, the execution of the tax duty is the payment in full by a payer of the relevant amounts of tax obligations within the period established by the tax legislation. That is, according to the current tax legislation there are two established requirements (quantitative and temporary) for the recognition of a taxpayer one who has fulfilled his tax duty properly:

a) payment of tax obligations in full;

b) payment of tax liabilities within the period established by law.

The norms of the Tax Code of Ukraine also prohibit the establishment of methods and procedure for the execution of tax obligations than those provided by the Tax Code of Ukraine (para. 38.3 Art. 38 of the Tax Code). Moreover, taking into account a taxpayer's status in relations with the subject of authority (supervisory authority), a payer can not have additional obligations than those provided by the current Tax Code of Ukraine. A taxpayer can not bear the negative consequences of the activity of other state authories which are obliged to control the financial institutions through which the payment of taxes and fees is settled [12]. In this case, it is the state that acts as an interested party that should take all possible measures to prevent violation of the rights and interests of bona fide taxpayers as well as for the timely and full fund revenues paid by such a payer through financial institutions. Otherwise, there will be a violation of the balance of public and private interests in the tax field, and a taxpayer will be obliged to double the execution of tax duty and the obligation to monitor financial institutions what is impossible. Such a situation is confirmed by the analysis of Art. 16 of the Tax Code of Ukraine Duties of a Taxpayer that, first, contains a full list of a payer's obligations, and second, it also establishes two criteria (quantitative and temporary) for the formation of the completion of the obligation to pay taxes and fees (para. 16.1.4 of the Tax Code of Ukraine).

Third, budget and tax legislations do not coincide in principle regarding the evaluation of the parties. Thus, the principal approach of financial-legal regulation (sub-sectors of which are budget law and tax one) regarding the existence of two parties (power and obligated) in the budget and tax regulation preserves. At the same time, if the execution of tax duty is associated, first of all, with the behaviour regulation of payers of tax and fees which are legal entities and individuals, the parties of budgetary relations radically differ from this. First of all, individuals are not the participants of the budget relations, at the same time, they are one of the main subjects of tax relations $[13 ; 14]$. Besides, legal entities-taxpayers can not be automatically considered the subjects of budgetary legal relations either.

Thus, according to Art. 2 of the Budgetary Code of Ukraine Determination of Basic Terms, one can found out the approach of a legislator to the parties-participants of budgetary relations (the main holders of budget funds, recipients of budget funds and holders of budget funds), but their authorities are associated with the receipt and 
expenditure of funds that come from the budget. Thus, for example, a recipient of budget funds is understood as a business entity, public or other organisation that does not have the status of a budgetary institution, authorised by the disposer of budgetary funds for implementation of the activities provided by the budget programme and receives on their implementation budget funds. So, the main condition of determining a recipient of budgetary funds is connected with receiving the funds from the budget instead of their paying or receipt to the budget. Thus, if we assume that the actions of a taxpayer, in whose behaviour the time of tax payment is evaluated, is related to the execution of his duty to transfer funds to the budget, then no provision of the budget legislation can be applied to the evaluation of these actions.

\subsection{Analysis of tax legislation and legislation which regulates the money circulation}

When maintaining the position on the complexity of regulation in determining the time of tax payment and, actually, banking legislation applying they often try to distinguish between the relations between a payer and the bank and those between a payer and the budget. The main problem here is reduced to the situations where a payer gave money to the bank in compensation of his tax duty and that is what he considers the moment of tax payment. Having received funds from a payer, the bank did not transfer them to the relevant treasury account for various reasons (bankruptcy, etc.).

But some researchers and judges note that it is advisable to distinguish between the onset of sanctions against a payer and tax repayment [15]. They believe that a payer should not be held liable in this situation, but the duty to repay the tax remains with a payer. A clarification of the relations between a payer and the bank separates from tax relations and goes into the sphere of private regulation.

Arguing such a position, in this situation they refer to para. 129.6 Art. 129 of the Tax Code of Ukraine according to which for violation of term of tax receipt to the budgets or state trust funds because of the fault of bank or the authority which performs treasury service of budget funds in which payers' accounts are opened in the electronic administration system of value added tax, such a bank / authority shall pay a fine for each day of delay, including the day of payment, and penalties in the amounts established by this Code as well as bears other responsibility established by this Code for violation of the order of timely and full receipt of taxes, fees and payments to the budget or state trust fund. At the same time, a taxpayer is exempt from liability for late or incomplete transfer of such taxes, fees and other payments to the budgets and state trust funds including accrued interest or penalties [7].

Therefore, such a logic of the supporters of the above position proves to be artificial. It is very difficult to distinguish between the relations of a payer and the state as well as the relations of a payer and the bank at the execution of tax duty. It is unlikely that the relations between a payer and the bank at the moment of tax payment should be regulated by dispositive means. The interests of the state can not be satisfied with any 
(even illogical and inconsistent methods), and the receipt of funds from a payer is the main aim under any circumstances, regardless of whether such a non-receipt is connected with violations in a taxpayer's behaviour.

Moreover, it should be taken into account that the bank in these relations acts as a subject that has obtained the state legalisation. Thus, the bank's violation at transfer of funds from a payer to the budget is the circumstance to which actions of the state led, namely, unreasonable granting a banking licence and improper control over the procedure for the introduction of the tempopary administration. Since a payer can not bear responsibility for unreasonableness in the actions of the state in granting a licence of the bank and the implementation of control functions on the market of financial and banking services.

Also, one should pay attention to the additional guarantees of tax legislation which are enshrined in para. 129.7 Art. 129 of the Tax Code of Ukraine. According to the mentioned norm, the violation committed in the result of the regulation of economic standards of such a bank by the Ukrainian National Bank that leads to a lack of free balance on such a correspondent account is not considered to be a violation of the term of transfer of taxes, fees and payments through the bank's fault. If in the future the bank or its successors recover solvency, the countdown of the term of transfer of taxes, fees and other payments starts with the date of such a recovery, that is, even in Art. 129 of the Tax Code of Ukraine, a legislator confirms the duty not of a taxpayer, but, namely, the Ukrainian National Bank to act as a regulator of commercial banks.

One more reason for the impossibility of extending the regime of dual execution of tax duty to a taxpayer as well as implementation of control by supervisory authorities exceptionally for the completeness and compliance with the terms of tax payment, but not the transfer of funds to the single treasury account is the provision of Art. 19-1 of the Tax Code of Ukraine. Thus, according to para. 19-1.1.5 para. 19-1.1 Art. 19-1, the functions of the supervisory authorities include, in particular, monitoring of compliance by the executive authorities of rural and village councils and councils of united territorial communities created according to the law and the long-term plan of formation of territories of communities, order of acceptance and accounting of taxes and fees from taxpayers, timeliness and completeness of transfer of the specified amounts to the budget. Namely, the movement of funds paid as taxes and fees within the treasury accounts (local governments, that is, state bodies) is under the control of the State Fiscal Service authorities (in the context of taxlegal regulation). In its turn, as it was noted, regarding tax payers, the supervisory authorities monitor only the timeliness and completeness of payment of taxes and fees, and, in fact, until their transfer to the bank. Control over compliance with the legislation by the bank when transferring a taxpayer's funds to the single treasury account is the subject of control of quite other authorities - the Ukrainian National Bank and the Deposit Guarantee Fund. 
At the same time, the textual analysis of the provisions of the current Tax Code of Ukraine shows that the concept of "tax payment" and "transfer of taxes" are identical. For example, Art. 54 Determination of Tax and Monetary Obligations of the Tax Code of Ukraine states that "the monetary obligation which concerns the amount of tax obligations from the tax which is subject to deduction and payment (transfer) to the budget in case of charge/payment of the income in a taxpayer's favour. A similar approach of a legislator can be traced in other articles of the Tax Code of Ukraine: Art. 126 Violation of the Rules of Payment (Transfer) of Taxes"; and Art. 127. Violation of the Rules of Charge, Withholding and Payment (Transfer) of Taxes at the Source of Payment and the like. The above allows to conclude that the transfer of taxes and fees as well as the execution of the tax duty of a payer ends at the time of payment of such taxes and fees in full and within the stipulated time. In its turn, payment of taxes and fees is completed at the moment of debiting the current account of a payer or transfer of a payer's funds to the cash desk of the bank that makes impossible the reexecution the tax duty in terms of taxes and fees.

\section{CONCLUSIONS}

Tax duty is defined as the obligation of a taxpayer to calculate, declare and / or pay the amount of tax and fee in the manner and within the terms determined by the Tax Code of Ukraine. In view of the above, on the basis of system analysis of Art. 1, 3, 4, 5, 16, 38 and 129 of the Tax Code of Ukraine, one can conclude that the execution of the tax duty by a payer is regulated exceptionally by the norms of tax legislation which include neither the Budgetary Code nor special Laws that regulate the monetary circulation issues. Under such a condition, the tax legislation does not impose any additional obligations on a taxpayer or the application of sanctions for the acts which led to the non-receipt of funds paid to them as taxes and fees, through the fault of other persons, in particular, banks. Proper execution of the tax duties by a taxpayer (payment within the period established by law and in full), but non-receipt of these funds to the single treasury account through the bank's fault can not lead to arising a duty of repayment of taxes or fees regarding such a taxpayer. Another approach of law enforcement would be the reason to impose on a taxpayer the obligation to pay taxes and fees twice. The execution of the tax duty is the payment in full by a payer of the relevant amounts of tax obligations within the period established by tax legislation.

Characterising the latest changes in the tax legislation of the country, the system of tax revenues and fees accruing eleven obligatory payments to the budget was structured, four of which, although established, accounted for and charged by local authorities and their cost level, compliance procedures are controlled by the state. The preconditions for the further productive functioning of the country's tax system are adaptation of new criteria for the collection of taxes and fees through the settlement of procedures for the 
calculation and payment of tax payments which are related to buiding a stable and efficient banking system in Ukraine.

Given the above, the main problems of tax system functioning in Ukraine include first, the fact that a large number of low-efficient taxes requires significant administrative expenses which exceed budget revenues; second, the contradictions and inconsistencies of certain tax laws, their instability, unsystematic provision of benefits and misrepresentation of the essence of certain types of taxes; fourth, a significant number of normative-legal acts on taxation which both taxpayers and employees of the Ukrainian State Fiscal Service should know and be guided by in practice; fifth, the lack of proper regulation of legal guarantees for participants of tax relations and the lack of transparent and effective mechanisms of rights protection of taxpayers; sixth, the tax system is now a factor of reducing the level of economic growth and investment activity and tax evasion stimulating.

\section{REFERENCES}

[1] Auspurg, K., \& Hinz, T. (2015). Factorial survey experiments. sage series: Quantitative applications in the social sciences. Thousand Oaks: Sage.

[2] Clayton, S. (2018). The Role of Perceived Justice, Political Ideology, and Individual or Collective Framing in Support for Environmental Policies. Social Justice Research, 31(3), 219-237.

[3] Timmermann, C. (2018). Contributive Justice: An Exploration of a Wider Provision of Meaningful Work. Social Justice Research, 31(1), 85-111.

[4] Kisska-Schulze, K. (2014). The Future of E-mail Taxation in the Wake of the Expiration of the Internet Tax Freedom Act. American Business Law Journal, 51(2), 315-363

[5] Kulik, J. M., \& Ermasova, N. (2018). Tax Expenditure Limitations (TELs) and State Expenditure Structure in the USA. Public Organization Review, 18(1), 53-69

[6] Mumford, A. (2015). Tax Complexity, Tax Salience and Tax Politics. Social and Legal Studies, 24(2), 185-201.

[7] Tax Code of Ukraine. Retrieved from https://zakon.rada.gov.ua/laws/show/2755-17

[8] Belous, V. V., Voronova, L. K., \& Golovasevich, O. O. (2011). Tax Code of Ukraine. Kharkov: Pravo.

[9] Chilton, A. S., \& Posner, E. A. (2018). Treaties and Human Rights: The Role of Long-Term Trends. Law and Contemporary Problems, 81, 1-30.

[10] Baranovskaya, I. V. (2009). Problems of Reforming the Tax System in Crisis Conditions. Actual Problems of the Economy, 8, 193-197.

[11] Ananieva, E. A. (2016). On the issue of special criteria for the classification of taxes and fees included in the tax system of Ukraine. Scientific Bulletin of the Dnipropetrovsk State University of Internal Affairs. Dnieper, 4(84), 108-114.

[12] Gladun, Yu. (2012). The tax system of Ukraine is developing according to world standards. Bulletin of the Tax Service of Ukraine, 2, 5-7.

[13] Bezverkhy, K. (2015). Administration of PIT in 2016: legislative innovations. Scientific and Practical Journal "Accounting and Audit”, 12, 26-35.

[14] Vishnevsky, V., \& Vetkin, A. (2009). Tax evasion: modeling the choice and actions of an economic entity. Ukraine Economy, 1-9, 15. 
[15] Hofmann, E., Gangl, K., Kirchler, E., \& Stark, J. (2014). Enhancing Tax Compliance through Coercive and Legitimate Power of Tax Authorities by Concurrently Diminishing or Facilitating Trust in Tax Authorities. Law and Policy, 36(3), 290-313.

\section{Mykola P. Kucheryavenko}

Doctor of Juridical Sciences, Professor

First Vice-President of the National Academy of Legal Sciences of Ukraine

Academician of the National Academy of Legal Sciences of Ukraine

61024, 70 Pushkinskaya Str., Kharkiv, Ukraine

\section{Yevgen M. Smychok}

Candidate of Juridical Sciences

Assistant of the Department of Financial Law

Yaroslav Mudryi National Law University

61024, 77 Pushkinskaya Str., Kharkiv, Ukraine

Suggested Citation: Kucheryavenko, M., \& Shmichok, Y. (2019). Moment of execution of the duty to pay taxes and fees: a tax-legal aspect. Journal of the National Academy of Legal Sciences of Ukraine, 26 (1), 25-35.

Submitted: 06/02/2019

Revised: $11 / 03 / 2019$

Accepted: 05/03/2019 


\author{
Рольф Кніппер \\ фо ранкфуртський університет \\ імені Йоганна Вольфганга Гете \\ ор ранкфурт-на-Майні, Німеччина \\ Олександр Миколайович Бірюков \\ Кафедра міжнародного приватного права \\ Київський національний університет \\ імені Тараса Шевченка \\ Київ, Україна
}

\title{
ТЕРИТОРІАЛЬНІ ГРОМАДИ У ЦИВІЛЬНО-ПРАВОВИХ ВІДНОСИНАХ
}

Анотація. В Україні, у процесі проведення правової реформи, досить активно оновлюється чинне законодавство. На шляху до впровадження циивілізованих правил ведення економічної діяльності необхідно належно обтрунтувати ключові у даній сфері конструкціiі. Тому основна мета роботи полягає у аналізі територіальних громад у циивільно-правових відносинах. У роботі розглянуто практику застосування в сучасній Україні не зовсім природної правової конструкції - права оперативного управління, щуо з'явилась за часів радянської влади і довгий час була ознакою сочіалістичного права. Було досліджено особливості застосування положень про відповідальність територіальних громад при розгляді справ про банкрутство юридичних осіб, створених ними, у контексті дослідження загальної проблематики відповідальності засновника за зобов 'язаннями підконтрольних підприємств. Особливу значимість таке дослідження набуває в контексті сучасної реформи місиевого самоврядування, зокрема децентралізащії влади. Встановлено, щзо для зменшення ризику постановлення спірних судових рішень необхідно внести зміни до Господарського кодексу Украӥни з метою наближення його окремих положень до сучасних умов ведення бізнесу. Одним з таких прикладів, як було наведено у иій статті, є право оперативного управління, що залишається в українському законодавстві з часів радянської доби. Право оперативного управління в радянській правовій системі відігравало свою роль, оскільки за відсутності повноцінного інституту приватної власності в соціалістичному праві через введення иієё правової конструкції забезпечувались виключні права держави в цивільному обороті $і$ за ї̈ допомогою здійснювався захист сочіалістичної власності. Автор вважає, щзо законодавцю необхідно виправити недоліки чинного законодавства і прибрати застрілі правові конструкиії, які можуть і у майбутньому створювати проблеми для учасників правових відносин майнового характеру. У зв 'язку з цим, вважаємо за доцільне підтримати ідею скасування Господарського кодексу Украӥни, ініційоване Міністерством юстииії України

Ключові слова: право оперативного управління, банкрут, боржник, кредитор, реєстр кредиторів. 


\title{
Rolf Knieper
}

Coethe University Frankfurt Frankfurt am Main, Germany

\author{
Alexander N. Biryukov \\ Department of International Private Law \\ Taras Shevchenko National University of Kyiv \\ Kyiv, Ukraine
}

\section{TERRITORIAL COMMUNITIES IN CIVIL LEGAL RELATIONS}

\begin{abstract}
On the way to the introduction of civilised rules of economic activity, it is necessary to properly justify the key constructions in this area. Therefore, the main objective of the work is to analyse the territorial communities in civil-law relations. The research work examines the practice of applying not quite natural legal construction, namely, in today's Ukraine operative management right that appeared during the Soviet times and has been an indicator of socialist law for a long time. The particulaties of applying the provisions on the responsibility of territorial communities when considering the cases on bankruptcy of legal entities established by them were investigated in the framework of the study of the general problematics of the founder's responsibility in accordance with the obligations of controlled enterprises. Such a research gains particular significance in the context of modern local self-government reform, in particular, power decentralisation. It was established that in order to reduce the risk of settling disputed court decisions, one should make amendments to the Commercial Code of Ukraine in order to approximate its individual provisions to the current conditions of running a business.
\end{abstract}

Key words: operative management right, bankrupt, debtor, creditor, register of creditors' claims.

\section{INTRODUCTION}

In Ukraine, in the process of conducting a legal reform, the current legislation is being actively updated. At the same time, there are still quite contradictory legal categories in the codified laws, in particular those that appeared in the days of the Soviet regime and have been indicators of socialist law. Among such legal categories, first of all, one should mention the right of operative management. It is a common knowledge that the right of operative management as a legal concept was first introduced into the legislation of the republics of the former Soviet Union after the adoption of the Foundations of Civil Legislation in 1961.

Previously, this legal concept played an important role in justifying the protection of the socialist property of state enterprises. However, today, in the conditions of market relations' approval and adaptation of legal regulation of relations in the field of economic activity to the needs of the free market such legal categories create certain difficulties in law enforcement practice in resolving property disputes. Thus, in judicial practice, there arise the situations when the courts, referring to the existing provisions of legislative acts, interpret the rules of these laws in different ways and make in some ways conflicting court decisions [1;2;3]. First of all, it comes to the legal norms of the 
Civil Code of Ukraine and the Commercial Code of Ukraine regarding certain provisions of liability for violated obligations of the civil-legal nature. However, there are examples of resolving property disputes with the participation of territorial communities in which certain court decisions are justified by the existence of specific relations between a founder and the enterprise based on the right of operative management.

Today, after rather a long and quite successful legal reform, such legal categories still remain in the Commercial Code of Ukraine. In modern science, certain aspects of the use of the right of operational management and full economic management in law enforcement practice were the subject of research in a number of publications, in particular, such scientists as Yu. Yu. Popov [4], O. I. Kharitonova [5], O. O. Kravchuck [6], A. G. Bobkova Ye. O. Zarudnev [7] and all.

The topic under research is actual because the approval of the rules of economic activity should focus on scientific concepts $[8 ; 9 ; 10]$. This problem is particularly relevant in the context of the modern reform of local self-government, in particular, the decentralisation of power. In the process of devolving powers to the local authorities, it is also stipulated to increase the responsibility of territorial communities and their representative bodies for the made decisions connected with effective use of property of local communities.

\section{MATERIALS AND METHODS}

The methodological basis of the research consists of various theoretical methods. With their help it was found that territorial communities were the owners of the property transferred by municipal enterprises to the economic management and other legal entities of public law - to the operational management. Territorial communities through the relevant bodies of local self-government exercise the right of management of the property transferred to the legal entities on the right of economic management or on the right of operative management. The method of analysis also allowed to reveal that territorial communities have a special legal capacity, by the content of which they can participate in civil relations in the framework of their authorities. At the same time, the powers regarding their participation in civil legal relations are mainly contained in the legislative acts of public law, but not private law which defines only the basis (basic parameters) of their participation in these relations.

For achieving a set aim there were also used:

- philosophical (dialectical) method - when studying the essence of the territorial community as a variety of participants in civil relations and the analysis of potential forms of participation of the territorial community in civil legal relations, namely, property relations and binding ones;

- legal (dogmatic) method - in clarifying the legal forms of participation of the territorial community in civil relations provided by the current legislation and the new Civil Code of Ukraine; 
- method of system-structural analysis - when studying the concepts of "subject of law" and "subject (participant) of legal relations" and the application of the results regarding such a subject as a territorial community;

- the method of comparative law - when comparing the provisions of the current legislation of Ukraine with similar provisions stipulated in the legislation of other countries.

Therefore, the use of methodological research approaches in the scientific work determine the relevant procedures for the interpretation of phenomena, based on the use of different groups of methods of scientific knowledge.

\section{RESULTS AND DISCUSSION}

\subsection{Particularities of bankruptcy cases consideration}

Ambiguous practice of application of provisions on responsibility of territorial communities developed at considering the cases on bankruptcy of the municipal enterprises, including application of subsidiary responsibility of the founder on obligations. This was the reason for addressing to the study of the legal status of territorial communities in civil turnover, including the right to dispose the property of enterprises established by the participants of civil relations. Of course, this raises the issue of operative management in the current legislation as an element of the classical institute of property rights. In this context, it became necessary to address to the nature of social relations which are the object of regulation by the relevant norms of one of the current codified acts in the sphere of regulation of private law relations.

In one of the court cases on bankruptcy (in particular, in bankruptcy case No. $5023 / 4388 / 12$ that were considered in the commercial courts, starting from 2012) the legal entity established by local government in the form of the municipal enterprise was declared bankrupt. A liquidation procedure was started and a liquidator was appointed.

The initiation of bankruptcy proceedings was preceded by the following: a founder of the legal entity - a territorial community - transferred the property to the enterprise established by it for use that is stipulated by the Commercial Code. In the result of performing its activity, with the use of the transferred property, an enterprise has accumulated debts to the state in the form of unpaid taxes and obligatory payments to the state trust funds. At the request of one of the creditors, a person is declared bankrupt. The liquidation procedure revealed the absence of property (the liquidation balance sheet drawn up by a liquidator did not contain property objects which can be recovered by law) necessary to repay debts. The liquidator, who was appointed by the court, filed an application for repayment of debts of the bankrupt by its owner, that is, the territorial community represented by the City Council.

It turned out that the problem was the existence in the domestic legislation of the legal structure of the operative management law which is difficult to link with the Central Civil Law Institute - the right of ownership. In this respect, one should note 
that the disputed legal relations, in particular, relations of the right of ownership and the activity of legal entities established on the basis of communal property of territorial communities governed by two laws are of the same force - the Civil Code of Ukraine and the Commercial Code of Ukraine. However, the right of operative management is stipulated only by the Commercial Code of Ukraine. Liquidation of an insolvent debtor is regulated by a special legislative act in the field of solving the debt problems, that is, by the Law of Ukraine On Solvency Renewal of a Debtor or Bankruptcy" [11] (hereinafter - Law on Bankruptcy).

As can be seen from the circumstances investigated in the above case, the municipal enterprise established by the territorial community accumulated the debts, and the enterprise itself did not have property objects on the right of ownership. This was due to the fact that until the court's recognition of the fact of bankruptcy (the local authority) a founder by his order withdrew the property from the management of the municipal enterprise. The court established that on the basis of one of decisions of session of the City Council in 2005, there had been withdrawn $94 \%$ of all property of the municipal enterprise which was in the operative management and used for performing its statutory activity. Among such property there were buildings, structures, equipment and vehicles (garbage trucks, trucks, excavator, trailer, tractor and buses). At the end of 2005, on the enterprise's balance sheet there were accounted only the surplus balances of fixed assets with absolute depriciation that actually made impossible further activity performance of the enterprise.

Debts to the state amounted to more than 240 thousand hryvnias. The main and the only creditor for the obligations of the enterprise was the state represented by specialised funds and other state institutions. Thus, the register of creditors includes the requirements of the Social Insurance Fund for Temporary Disability, State Tax Inspection, Pension Fund of Ukraine, Fund of Obligatory State Social Insurance of Ukraine against Unemployment, Social Insurance Fund against Accidents at Work and Occupational Diseases. Any other creditors were not included in the register [12].

In this case there was also considered the application of a liquidator on the debts recovery of the municipal enterprise according to the register approved by the court from the founder-territorial community. In the court, the objections of the City Council were based on the fact that neither the current legislation nor the founding documents of a bankrupt stipulate the liability of a founder for the obligations of the municipal enterprise, therefore the territorial community represented by the City Council should not be responsible for the obligations of the municipal enterprises established by it.

It should be noted here that a pre-trial investigation was also conducted in the framework of this bankruptcy case with the aim to check if there exist whether there are in actions of a founder (the City Council) the elements of a criminal offense under Bringing to Bankruptcy Art. [13]. 


\subsection{Particularities of property rights implementation}

It is known that the relations on possession, use and disposal of property are regulated by civil law. The Civil Code of Ukraine classifies territorial communities together with the State of Ukraine, the Autonomous Republic of the Crimea, foreign states and international organisations as participants in civil relations (Art. 2 of the Civil Code of Ukraine) [14]. Art. 175 of the Civil Code of Ukraine (Responsibility for the Obligations of Territorial Communities) directly establishes that territorial communities are responsible for their obligations by their property, except for the property that can not be recovered under the law.

The particularities of certain property rights implementation regarding certain categories of legal entities are stipulated by the Commercial Code. In accordance with the content of operative management right enshrined in the Civil Code of Ukraine, the owner of the property exercises control over the use and preservation of the property transferred to the operative management directly or through the authorised body and has the right to withdraw from the business entity unexpended balances as well as property that is not used or used for other purposes (Art. 137 of the Commercial Code of Ukraine) [15].

During the consideration of the above case, the commercial courts of first and appeal instances, with reference to the provisions of the Commercial Code of Ukraine established that the property of the municipal enterprise was in operative management of this enterprise and could not be included in liquidation weight and used for repayment of debt to creditors. Such an approach is erroneous. As on the basis of the analysis of the relevant norms of the current legislation in the context of understanding the principles of civil law in general and the nature and content of property rights, the following can be noted.

1. According to the norms of the Commercial Code, the municipal unitary enterprise is formed by competent local government body in the administrative order on the basis of the separated part of municipal property which is assigned to the enterprise with the right of operative management (Part 1 and Part 3 Art. 78 of the Commercial Code of Ukraine).

In accordance with the law, a founder forms the authorized capital of the established enterprise, approves the Charter, distributes the incomes, directly or through the Head who is appointed by the founder, manages the company and forms its personnel, solves the issue of reorganisation and liquidation of the enterprise (Part 4 Art. 63 Commercial Code of Ukraine) as well as approves the reports on the performance of the subordinate enterprise.

As can be seen from the analysis of the relevant provisions of the Commercial Code, such an enterprise is under full control of the owner-territorial community which is represented by competent local government. This is also confirmed by Art. 137 of the Commercial Code (Right of Operative Management): the owner of the property (ter- 
ritorial community) assigned to the business entity (municipal enterprise) on the right of operative management, exercises control over the use and preservation of the property transferred to the operative management directly (territorial community) or through the body authorized by it (local self-government body).

The responsibility of the state for the obligations of a legal entity established by it is directly stipulated regarding state-owned enterprises [16] - in case of insufficient funds on the account of the state enterprise, the state, represented by the authority in which field of management it is included, takes over full subsidiary responsibility for the enterprise's obligations (Art. 77 of the Commercial Code of Ukraine). Such kind of responsibility for the obligations of another, but similar by its legal status with the state enterprise, entity- municipal enterprise is not directly stipulated by the law. At the same time, the provisions of this law on the legal status of the municipal unitary enterprise state that the particularities of economic activities of municipal unitary enterprises shall be determined in accordance with the requirements of the Commercial Code of Ukraine regarding the activities of commercial state or state enterprises and Part 10 Art. 78 of the Commercial Code of Ukraine). In other words, the legal regime of municipal enterprises in economic relations is equal to the legal status of state enterprises for the obligations of which in case of lack of funds the founder is responsible.

Therefore, in accordance with the provisions of the Commercial Code of Ukraine, the activities of the municipal enterprise should be also regulated by the norms on the activities of state enterprises (Art. 76 and 77 of the Commercial Code of Ukraine), including also provisions on subsidiary responsibility of the authority that created the legal entity. In case of insufficiency of the funds which are at the disposal of state and municipal enterprises, the founder takes over full subsidiary responsibility for the obligations of such an enterprise and Part 7 Art. 77 of the Commercial Code of Ukraine).

2. For conducting a comprehensive analysis of the legal regulation of municipal enterprises, one should also take into account the general provisions of the Commercial Code. The responsibility of the founder of the municipal enterprise consists in repayment of a debt created by the enterprise in case of its liquidation. This follows from the understanding of the general principles of running an economic activity established in this system-forming law. Art. 5 of the Commercial Code contains a reference to the constitutional principles on which should be based the rule of law in the field of management. Thus, this article establishes that the basis of the legal economic order in Ukraine is the social orientation of the economy and the prevention of the use of property to the detriment of person and society.

The general understanding of this provision makes it clear that the law stipulates the duty of economic activity participants to properly use the property, to pay taxes and make obligatory payments to the state trust funds including to repay debts in case of liquidation of the controlled enterprise.

3. Although the right of operative management, provided by the Commercial Code, is not entirely consistent with the generally recognised understanding of ownership that 
is based in three elements (sphere of competence): possession, use and disposal of property, for the purposes of this analysis it is important to pay special attention to the legal nature of the relevant legal relations which are regulated by the Civil Code [14].

By its nature, the right of operative management is similar to the right to use someone else's thing. When using this right by the general rule, an individual is obliged not to violate the rights and legally protected interests of citizens, legal entities and the state.

Another closest in essence legal regime of property transferred for temporary use is the construction of management of other people's property. In accordance with the provisions of Art. 1029-1045 of the Civil Code (Chapter 70 Property Management) under the property management agreement, the founder of the management transfers the property to the other party - the manager - for a certain period of time, and the other party undertakes to carry out on its own behalf the management of this property in the interests of the founder of the management. The main aspect in the legal regime of management of other people's property is that the law directly provides for subsidiary liability of the owner of the property for property claims against the manager.

In this context, one can not but refer to one of the most important principles of property rights which is set out in the Civil Code as follows: property obliges ( Part 4 Art. 319 of the Civil Code). In a broad sense, this principle should be understood in the way that the owner of the property is obliged to use his property in the manner that should not do any harm the others including the state.

According to the provisions of the Civil Code, the enterprise is a property complex which is real estate by legal status (Part 3 Art. 191 of the Civil Code). Therefore, it is absolutely logical that the owner of the property is responsible for the proper use of the property.

The territorial community in civil turnover acts as an ordinary participant in civil law relations (Art. 2 of the Civil Code). It can establish legal entities under public law: municipal enterprises, joint municipal enterprises, educational establishments, etc (Part 2 Art. 169 of the Civil Code).

The Civil Code of Ukraine establishes that the municipal ownership includes property including funds which belong to the territorial community, and property management which is in municipal ownership is fulfilled directly by the territorial community and the local governments created by it (Art.327 Right of Municipal Ownership of the Civil Code of Ukraine).

An important feature of the legal status of the territorial community is that it acts in two qualities in relation to the legal entity established by it: as the founder of the enterprise (the owner of the property complex) and as the owner of the property that was transferred for temporary use.

In this case, the actions of the enterprise's owner (territorial community) can be regarded as such that not fully meet the requirements of the law. The owner of the property which he transferred for use to the controlled legal entity, did not ensure its proper use, namely, did not exercise effective control over the use of his property that 
led to the violation of the rights of the others. It is important to note that these persons were recognized by the court as bankruptcy creditors, and their claims in the amounts established by the court are included in the register of creditors of the debtor in the bankruptcy case.

4. The effective use of municipal property objects is included in the duties of the owner of municipal property. It is directly stipulated by the Law of Ukraine On Local Government in Ukraine [17] in the provisions which concern definition of the concept of the municipal property right: this is the right of the territorial community to own, expediently, economically, effectively use and dispose of property at its discretion and in its own interests that is put to it, both directly and through local governments (Art. 1 of the Law).

5. One of the basic rules in the legal regulation system of insolvency relations is the obligation of the founder to take all necessary measures to prevent bankruptcy. This rule is stipulated in the Law on Bankruptcy. According to Art. 5 of this Law, the founders, including the state and territorial communities as participants of civil legal relations, are obliged to take necessary and timely measures to prevent bankruptcy of the debtor in order to prevent loss of solvency.

In the framework of measures on bankruptcy prevention of the individual by the founder can be granted financial assistance in the amount sufficient for the repayment of monetary obligations to creditors including obligations to pay taxes and fees (obligatory payments), insurance premiums for compulsory state pension and other social insurance. The above law stipulates separate procedure for this: reorganisation of the debtor before initiation of bankruptcy proceedings. In this case the specified requirement of the law was not complied with.

In accordance with the relevant provisions of the Law On Bankruptcy, the reorganisation of state-owned enterprises before the initiation of bankruptcy proceedings is carried out at the expense of the state budget of Ukraine, state enterprises and other sources of financing (Part 6 Art. 5 of the Law on Bankruptcy). By analogy and in accordance with the above rules, the same procedure should be applied to enterprises of municipal ownership.

Thus, a individual who fails to comply with such a requirement of the law can be held liable for negative consequences for the controlled enterprise in the result of failure to comply with the provisions of the law.

6. The above arguments are correlated with the case law of the European Union.

The European Court of Human Rights in some of its decisions, in particular, in "Ponomariov against Ukraine" Case presumes that the participants of civil legal relations are of legitimate expectations (which are usually based on clear provisions of law) as to what their contractors will duly perform their obligations. Even if the legislative acts do not directly establish additional (subsidiary) liability of the founders for the debts of legal entities established by them, such an obligation is motivated by reference to the theory of legitimate (legitimate) expectations [18]. This also applies and even to 
a greater extent to the obligation to pay taxes and make obligatory payments to the budget and state trust funds. Taxes and revenues from the collected obligatory payments to the state special funds are the main source of formation of budgets (state and local) which are a necessary condition for the state to perform its basic social function, that is, to ensure the functioning of state institutions and financial stability of the state as a whole and territorial communities. After all, it is necessary for preventing the destruction of the statehood's foundations.

In another case related to bankruptcy which was considered in 2014 ("Liseitseva and Maslov against the Russian Federation" Case), The European Court of Human Rights directly noted that an enterprise that does not have sufficient institutional and operative independence from the founder (in this case of the municipal authority) should be responsible for the debts of the controlled enterprise [13].

This conclusion fully corresponds to the practice of the Constitutional Court of Ukraine which in one of its decisions found that the impossibility of the creditor in the case by the constitutional proceeding of the municipal enterprise in the court order to obtain sustaining for his claim that has already been found by the court (put on the register of creditors) can be regarded as a violation of the right to a fair trial [19].

The author states that taking into account the above, a single logical conclusion in the above contradictory situations can be as follows: according to the norms of the commercial and civil laws, bankruptcy law and case law of the European Union, the territorial community as the owner of the enterprise and property transferred to it in use on the right of operative management is to pay off debts in the liquidation procedure of the controlled enterprise recognized as bankrupt.

This conclusion is based on the fact that the territorial community as a full participant of civil turnover in the person of the Local Council, the founder of the municipal enterprise, is the owner of the property transferred to the enterprise for use and should repay the debts of the controlled entity which is liquidated according to the rules of bankruptcy law. According to the provisions of the Civil Code of Ukraine, such an enterprise is not a full owner of the property and in accordance with the definition of the right of operative management does not have the authority to dispose of this property at its discretion and in its own interests.

From the above example it is clear that the practice of applying certain norms of legislative acts in Ukraine is still affected by the Soviet legal conceptions which are unclear from the standpoint of modern law and cause difficulties and problems in law enforcement practice.

Today, the courts are trying to make decisions which are logical and understandable for citizens. Besides, applying the conflicting legal categories which are not inherent in the modern legal doctrine in law enforcement practice can give additional opportunities for (legal entities) individuals to avoid fulfilling obligations and not to repay debts to participants of economic activity even in case of termination of their activities. 


\section{CONCLUSIONS}

So, territorial communities acquire and exercise civil rights and obligations through local self-government authorities within the limits of their competence established by law. Local self-government bodies are legal entities with their own powers, within the limits of which they act independently and are responsible for their activity in accordance with the law. Rural, township, city, district in the cities, district and regional councils have the seals with the image of the State Emblem of Ukraine and their names as well as accounts in bank establishments of Ukraine. The author notes that the problem issue is to avoid similar conflicts in law enforcement practice without making changes to the Commercial Code. One of such examples, as mentioned in this article, is the operative management right which has remained in the Ukrainian legislation since the Soviet era. The author notes that the operative management right in the Soviet legal system played its role because given the absence of a fullfledged institution of private property in socialist law and for the introduction of this legal structure, the exclusive rights of the state in civil turnover were ensured and with its help the protection of socialist property was carried out.

The author considers that the legislator needs to correct the shortcomings of the current legislation and remove outdated legal structures that in the future cause problems for the participants of the legal relations of property character. In this regard, we consider it reasonable to support the idea of abolition of the Commercial Code of Ukraine initiated by the Ministry of Justice of Ukraine.

Consequently, the state is responsible for the damage caused to other parties by the unlawful actions of its authorities and officials as well as by acts recognised as unconstitutional. This means that if in the result of the actions of such authorities, officials or acts other participants in civil turnover are caused losses, they are compensated by the state.

\section{REFERENCES}

[1] Toya, L., \& Clark, B. (2018). Beyond Bias: Cultural Capital in Anti-Discrimination Law. Harvard Civil Rights-Civil Liberties Law Review, 53(2), 381-443

[2] Devlin, P. A. (2018). Jurisdiction, Exhaustion of Administrative Remedies, and Constitutional Claims. New York University Law Review, 93(5), 1234-1270.

[3] Caruso, D. (2018). Non-Parties: The Negative Externalities of Regional Trade Agreements in a Private Law Perspective. Harvard International Law Journal, 59(2), 389-430.

[4] Popov, Yu.Yu. (2004). The concept of the right of economic jurisdiction in the decision of a foreign court. Ukrainian Commercial Law, 5, 25-36.

[5] Kharitonova, O. I. (2008). The right of economic management and the right of operational management: problem issues. Actual Problems of State and Law, 38, 245-249.

[6] Kravchuk, O. O. (2011). Some issues of economic management and operational management of property of state property. State and Law, 52, 232-238.

[7] Bobkova, A. G., \& Zarudnev, Ye.O. (2016). Regarding the economic management and operational management of property in comparison with the laws of the Federal Republic of Germany. Bulletin of the National Academy of Legal Sciences of Ukraine, 1 (84), 76-81. 
[8] Montiel, I., Christmann, P., \& Zink, T. (2019). The Effect of Sustainability Standard Uncertainty on Certification Decisions of Firms in Emerging Economies. Journal of Business Ethics, 154(3), 667-681.

[9] Capers, B. (2018). Evidence without rules. Notre Dame Law Review, 94(2), 867-907

[10] Akande, D., \& Tzanakopoulos, A. (2018). Symposium: the crime of aggression before the international criminal court. European Journal of International Law, 29(3). Retrieved from http://www.ejil.org/article.php?article=2912\&issue=144

[11] Law of Ukraine "On the Restoration of the Debtor's Solvency or Recognition as a Bankrupt”. (1992). Retrieved from https://zakon.rada.gov.ua/laws/show/2343-12

[12] Carle, S. D. (2014). Conceptions of Agency in Social Movement Scholarship: Mack on African American Civil Rights Lawyers. Law and Social Inquiry, 39(2), 522-546.

[13] Prigusa, P. D. (2007). The economic and legal aspect of the grounds for liability for bankruptcy and the qualification of crimes. Bulletin of the Prosecutor's Office, 1 (8), 86-94.

[14] Civil Code of Ukraine. (2003). Retrieved from https://zakon.rada.gov.ua/laws/show/435-15

[15] Commercial Code of Ukraine. (2003). Retrieved from https://zakon.rada.gov.ua/laws/ show/436-15

[16] Mashkovska, L. (2014). State Enterprise: notions, signs and legal nature. Legal Ukraine, 2, 57-61.

[17] Law of Ukraine "On Local Self-Government in Ukraine”. (1997). Retrieved from https:// zakon.rada.gov.ua/laws/show/280/97-\%D0\%B2\%D1\%80

[18] Belyanevich, O. A. (2016). Concept of legitimate expectations and problems of its application by courts in Ukraine. Private Law and Entrepreneurship, 16, 41-45.

[19] Ministry of Justice explained why it is necessary to abolish the Commercial Code. Retrieved from https://www.ukrinform.ua/rubric-society/1949157-u-minusti-poasnili-comu-trebaskasuvati-gospodarskij-kodeks.html.

\title{
Rolf Knieper
}

Dr. Habilitat, Professor

Coethe University Frankfurt

60323, 6 Theodor-W.-Adorno-Platz, Frankfurt am Main, Germany

\author{
Alexander N. Biryukov \\ Doctor of Juridical Sciences, Professor \\ Department of International Private Law \\ Institute of International Relations \\ Taras Shevchenko National University of Kyiv \\ 01033, 60 Volodymyrska Str., Kyiv, Ukraine
}

Suggested Citation: Knieper, R., \& Biryukov, A. N. (2019). Territorial communities in civil legal relations. Journal of the National Academy of Legal Sciences of Ukraine, 26 (1), 36-47.

Submitted: 31/01/2019

Revised: 18/03/2019

Accepted: 28/03/2019 


\title{
ЗАВДАННЯ ВНУТРІШНЬОЇ ДЕРЖАВНОЇ ДІЯЛЬНОСТІ В ПРОЦЕСІ СОЦІАЛІЗАЦIÏ
}

\begin{abstract}
Анотація. У статті розглядається категорія сочіалізації внутрішньої діяльності держави. Показано важливість застосування соиіологічного підходу до оптимізації взаємодї державних інституцій, суспільства і особистості. У дослідженні запропоновані вимоги до ролі держави в прочесі правової сочіалізаџії. Показано необхідність активної участі держави в правовій сочіалізаиї на нових засадах для усунення наслідків специифічної соціалізації в тоталітарній державі, коли вона пригнічує діяльність інших агентів сочіалізації. Поряд з ичм показано нові перспективи, які отримує держава в демократичному суспільстві від соиіалізачії. Наразі для украӥнського суспільства є характерним наявність протиріччя між курсом на побудову правової держави і громадянського суспільства з однієї сторони, і правовою реальністю - з іншої, особливістю якої є те, щуо право до сих пір ще не стало основою відносин у намому суспільстві; органи державної влади та їх посадові особи дуже часто ігнорують норми права, популярним є, так зване, «телефонне право». Нерідко приймаються нормативно-правові акти, які суперечать один одному, спостерігається тенденція переваги підзаконних нормативних актів над законами, щзо посилює серед населення правовий нігілізм, який є перешкодою розбудови правової держави. Потребують вирішення на державному рівні питання подальшого розвитку правосвідомості населення, подолання правового нігілізму, задоволення потреб громадян у одержані знань про право, формування у них поваги до нього. Держава повинна створити умови для сочіалізації та самореалізачії суспільства, дійсно визначаючи тим самим стимули реальної участі людей в громадському житті, розширювати соиіальну базу суспільних перетворень, культурного і економічного відтворення. Досягається иче завдяки иілеспрямованій та злагодженій роботи всіх державних органів, коли суспільство відчуватиме їх діяльність, позитивні зміни і той факт, щзо соціальні изінності стають сталими, гарантованими та звичними, а державне управління полишають свавілля та суб〉єктивізм.
\end{abstract}

Ключові слова: соціалізація, держава, демократія, громадянське суспільство.

Olga G. Koban

Department of Theory of Law and State Taras Shevchenko National University of Kyiv Kyiv, Ukraine

\section{TASK OF INTERNAL STATE ACTIVITY IN THE SOCIALISATION PROCESS}

\begin{abstract}
The article deals with the category of socialisation in domestic activity of the state. It shows the importance of sociological approach to optimising the cooperation of public
\end{abstract}


institutions, society and an individual. The research proposed the requirements for a role of the state in legal socialisation. The article shows the necessity for active participation of state in socialisation. It also describes specific character of socialisation in the totalitarian state where it lies in striving to weaken the impact of the other agents of socialisation. The article notes new perspectives obtained by the state in the democratic society in order to affect the socialisation. The research also formulates the basic concepts and principles of interaction between the society, individual and state which guarantees the rule of law in the modern legal system which is a prerequisite for the formation of a law-governed state and civil society.

Key words: law, socialisation, government, democracy, civil society.

\section{INTRODUCTION}

Radical changes in the economic, social and political spheres, the democratisation of all spheres of public life and the complexity of the social tasks that the society is now putting forward before the state. The reduction of "person-state" distance became possible due to the creation of objective prerequisites for the broad selfrealisation of the individual in policy and law as well as the approval of the legal basis for the interaction of state power with civil society. Through this there occurs the formation of a socially active individual with a high level of legal consciousness and legal culture and the recognition of law as the main regulator of social relations. The transition from a narrow normative understanding of law as a right of power to a liberal understanding of law as a measure of freedom determined humanistic value content of law in which universal values prevail i.e. law is the means with the help of which they are implemented. The law is not limited to the role of the normative regulator, but actively affects the social sphere, encouraging social groups, state and society as a whole to certain forms of behaviour and interaction with one other, in the result of which they have certain connections with society. Thus, the law ensures the inclusion of individuals and groups in a single system of social organisation. This led to extensive research of not only the main function of law, namely, the regulation of social relations, but also such a specific function as legal socialisation. The expansion of research fields continues, concepts, types and functions of socialisation of the individual are specified including the legal one, the study of its mechanism and institutions deepens. These studies are based on the definition of socialisation of an individual as a complex two-way process of constant and uninterrupted interaction of an individual with his social environment. There occurs not only the formation of an individual under the impact of society through its institutions, but also the reverse process of formation of society and state under the impact of the social activity of individuals. An individual, acting in the social environment, changes and improves the state and society, at the same time changing himself and forming new features and properties.

Consequently, legal socialisation is a two-way process of interaction between an individual and society in which both parties are active. An individual, as an object of 
legal socialisation, is characterised by legal activeness who can himself choose the main directions of this process, acting both as an object and a subject of legal socialisation. Therefore, in the process of legal socialisation, not only society does contribute to the formation of an individual, but also an individual, entering the system of social and legal relations, has an active impact on society. This point of view is also shared by such jurists as V. M. Kudriavtsev and V. P. Kazymyrchuk noting that socialisation (including legal socialisation) includes, on the one hand, direct impact of social conditions and various social institutions on a person with the aim of involving him in the system of concepts, evaluations, ideas, social norms and other cultural values adopted in the society, on the other hand, the social activity of the person in the process of socialisation and the formation of personality. A person, acting in the social environment, changes and improves it, at the same time, he changes his own essence as well as forms new features and properties in himself. So, a person in the process of socialisation, in particular, legal socialisation acts as an object and subject that affect the outside world [1].

Recognition of socialisation as a two-way process which contains, on the one hand, the assimilation of social experience by an individual by entering into the environment, the system of social relations, and on the other hand, the process of independent reproduction by an individual of the system of social relations through his own activity and active involvment in the social environment, leads to the increased attention of scientists and expands the scope of research due to a significant number of problematic issues related to this process. Despite the fact that socialisation is a process of multilateral interaction, from the standpoint of law, it is studied mainly through the prism of its influence on the formation of personality. The reverse impact of socialisation on the society and the state, in particular, the transformations the state is subjected to, which in one way or another is "socialised" in its activity is not sufficiently studied. Therefore, the problem of the state as an object of socialisation, which is under the impact of an individual's social activity, is of considerable scientific and practical interest.

The importance of this problem is indicated by the necessity of the modern Ukrainianian society in the implementation of different forms and means of socialisation. The necessity for theoretical justification of the aims and forms of activity of state authorities in this direction, determines the importance of such a characteristics of modern society as the level of socialisation achieved by the state in its relations with the other subjects. Under this condition, there is the destruction of traditional forms of socialisation based on the regulation of the state of human life path, expansion of options for life strategy, growth of personal responsibility for a successful or unsuccessful decision, appearance of new social intermediaries, not inherent for self-determination and socialisation of the past generations, diversity of ownership forms, new sources of information, etc.

In connection with the novelty, the problem of subjectivity of the state in the process of socialisation is determined, first, by the inconsistency of the old forms of state policy 
to the needs of the society as a whole, and the expectations of an individual. Second, this type of state activity is characterised by an unsystematic and jerky character caused by insufficient formation and unclear understanding by the state authorities of their role in the process of socialisation. This can be partially explained by the lack of relevant theoretical developments.

In connection with the changed paradigm of the state policy directed, figuratively speaking, on the address of the state "face to the people", responding to the general and special needs of every citizen, socialisation is of great importance as a kind of space and a determinant of the state activity.

\section{LITERATURE REVIEW}

The democratisation of the social system and power, first of all, finds its expression in a fundamentally different evaluation of the role of a person and his socialisation. Socialisation in terms of democracy creates the conditions for motivating a person to "enter" the power. Along with this, socialisation is responsible for the "quality" of power subjects. As fairly noted by B. de Jouvenel, to continue its existence, the government should "get socialised". Power socialisation is expressed in its orientation to the values and needs of people as well as in the ability to consolidate itself in customs, moral values and norms.

The analysis of the modern scientific sources shows that the problem of transition to the socialised, human-centered principle of organising and implementation of power, when power is as close as possible to the needs of the individual, becomes highpriority in the current period of reform and renewal of epy Ukrainian society in terms of democracy. It is within the framework of civil society that socialization is organized, combining and taking into account the interests of various social forces, which involves clashes, contradictions and conflicts between them.

Among the important determinants of socialisation in different types of societies one should note, first, its dependence on the level of socio-historical development, social division of labour, socio-economic structure of society, the degree of understanding of personality (individuality) by the state as an independent value. Second, one should note the level of interdependence between an individual and society that can be empirically defined as an individual's immersion in society.

Contrary to this interpretation of socialisation, in the 60-ies and 70-ies of the XXth century, both in foreign and in Russian philosophy and sociology there appered the theories that consider an individual not passive, but an active participant of socialisation, recognising him at the same time as both an object and a subject of socialisation.

As noted by B. D. Paryhin socialisation is not reduced to the fact that a person acts as a passive object of the external impact. Socialisation is not possible without the active participation of a person himself in the process of assimilation of social experience and culture, when a person is not an object, but rather a subject of social relations [2]. 
In the early XXth century, interest in socialisation was aroused from the side of scientists in connection with the study of the problem of the correlation of a person to culture. And the term "socialisation" was interpreted as the process of individual's assimilation during his life of social norms and cultural values of the society he belongs to [3].

Socialisation was studied in the research works of such scientists as M. Veber, V. Zombart, K. Marks, P. Sorokin, G. Spencer and all.

\section{MATERIALS AND METHODS}

The system of methodology of legal research that forms the structure of interaction between society and state and shows the place of an individual in this system of interaction is mainly theoretical. The idealistic system of research ensures the purity of the analysis without taking into account the national particularities of the force of law and real problems of the legal system deform the subject under study through the hyperbolisation of one of its key elements.

The formalisation of the main elements of legal research is due to the functionality of state authorities. The determination of state authorities that can be attributed to the formation of the structure of the socialisation mechanism depends on the formalised requirements for state authorities. Through the formalisation of the apparatus of state authorities, it is possible to draw conclusions what state authorities can and will participate in interaction with society in the aspects of socialisation activity of such authories.

In the process of our research we use methods of analysis because in the system of research of various components of the concept of "socialibiation" it is possible to determine the characteristics of the formation of individual aspects. It also affects the formation of an integrated approach to the determination of the conceptual apparatus of the research. Then it is possible to determine from what position the conceptual apparatus is considered for the aims of the article.

An important component of this research is the use of a system-structural method to determine socialisation in the system of formation of the directions of the state's internal activity. The use of a systematic approach to the formation of the place and system relations the concept of socialisation in the state's internal activity.

Separately, the hermeneutical method is used in the system of such a research since the main structure of the material is based on the formation of the main components of the concept that, depending on the elements of the research, presumes different ways of understanding the system of interaction of dependent elements.

In the result, the generalisation allows to formulate the main categories of conclusions and set the main tendencies of further scientific research on this topic. The generalisation also allows to achieve the main concept of the proposed thesaurus and formation of a single approach to the basic terminology and systems of interaction of 
its structural elements. Also, the methodology makes it possible to formulate the position of a single approach to the components of the authorities and ways of implementing these authorities through the paradigm of perception of socialisation of the state's activity.

\section{RESULTS AND DISCUSSION}

The preservation of the state's role in terms of growing problems of the XXIst century and the nessesity to comply with the foundations of natural self-regulation of the civil society cause the necessity to determine the boundaries of the state intervention, the use of positive opportunities of impact and neutralisation of negative factors. The necessity for theoretical and methodological realising the state as a key subject of socialisation caused by the existence of a constantly recurring public demand for another model of public policy in matters of the internal activity. Without any doubt, in response to this public request, one of the defining qualities of the new paradigm of the state's internal activity and its interaction with the society should be socialisation.

The term "socialisation" derived from political economy, its original meaning was "socialisation" of land, means of production and the like. Nevertheless, the understanding of the problem of socialisation began long before the spread of this term. Socialisation is the process of integration of an individual into the society and inclusion in various types of social communities (group, social institution or social organisation) by mastering the elements of culture, social norms and values on the basis of which socially significant traits of an individual are formed. As noted by I. S. Kon the term "socialisation" is ambiguous and its interpretation by different authors does not coincide [4].

Considering socialisation as an individual's adaptation to the existing order, the formation of externally approved behaviour focused on specific life situations and the formation of a well-defined system of social roles [5]. A similar definition is given in the philosophical dictionary edited by Shynkaruk who notes that socialisation of an individual occurs through the society's impact on an individual when he assimulates some social values due to being in the certain social environment as well as on the psyche of an individual with the help of different social institutions (family, school and labour collective) with the aim of forming his certain traits [6].

Also, the versatility and diversity of socialisation are evidenced by the following circumstances:

- first, it is the presence in the process and mechanism of socialisation of both organised and spontaneous agents and channels of socialisation;

- second, it is the individualised nature of socialisation which is reproduced in social forms of implementation;

- third, it is a multi-level and multifaceted the structure of the socialisation mechanism in view of the diversity of objective and subjective factors; 
- fourth, it is the complexity of evaluation of the socialisation effectiveness caused by the difficulties of identifying social norms and social normativity.

All of the above together necessitates a discussion of socialisation, taking into account the different levels of abstraction, as socialisation processes occurr at both microand macrolevel.

Among the important determinants of socialisation in different types of societies one should note, first, its dependence on the level of socio-historical development, social labour division, socio-economic structure of the society to a certain extent and the state's understanding of personality (individuality) as an independent value. Second, one should note the level of interdependence between an individual and society that can be empirically defined as an individual's immersion in society.

Contrary to such an interpretation of socialisation in the 60s and 70s of the XXth century, both in foreign and domestic philosophy and sociology there appear the theories that consider an individual as an active participant of socialisation, recognizing him both an object and a subject of socialisation. As noted by B. D. Paryhin socialisation is not reduced to the fact that a person acts as a passive object of external impact. Socialisation is not possible without the active participation of a person himself in the process of assimilation of social experience and culture, when a person is not an object, but rather a subject of social relations [2].

In the early XXth century, interest in socialisation was aroused from the side of scientists in connection with the study of the problem of the correlation of a person to culture. And the term "socialisation" was interpreted as the process of individual's assimilation during his life of social norms and cultural values of the society he belongs to [3].

In the same way the state at all times assimilates the social norms and values of the society it belongs to. If in the Soviet period the key task of the state's internal activity was to build communism, now one of these tasks is socialisation.

The legal socialisation of an individual should be understood as the process of formation of a person with the appropriate level of legal consciousness that it manifests itself in its involvement in the system of legal values of the society, its assimilation of the system and social and legal activities of an individual aimed at adjusting the social values.

The mechanism of legal socialisation is also associated with the activities of legal and social institutions as well as special means of legal impact and control. At all stages of legal socialisation the society with the help of its institutions and agents has a direct impact on an individual. As a result, there occurs a transfer of relevant experience and knowledge, skills, systematic values and norms from generation to generation. Very often the concepts of "agent" and "institute" of socialisation are equaled. However, separate singling out the agents and institutions of legal socialisation are determined by the level of their connection with the object of legal socialisation. 
In particular, the institution can be defined as a socio-political association, a social group, a member of which is an individual or a state authority, institution, non-governmental organisations that have an impact on it as subjects of legal socialisation. Under this condition, the subject through which the transfer of legal values is directly carried out will act as an agent of legal socialisation whereas the individual the actions of institutions and agents are directed to is the object of legal socialisation.

So, institutions of legal socialisation of an individual introduces a certain system of legal values through their agents that also provide a direct connection of the society with the object of legal socialisation.

According to S. M. Koretsky, the main institutions of legal socialisation are family, school, electronic mass media and communications and immediate environment (people with whom we work, study and spend leisure time) [7].

Thus, the institutions of legal socialisation is the state represented by state authorities, higher educational establishments, labour collectives, various associations of citizens, schools, preschool establishments, family, etc., and its agents, that is, direct participants of the legal socialisation process of an individual are parents, relatives, friends, teachers, officials, employees, etc. It is through the activities of institutions and agents of legal socialisation that external factors have an impact on an individual.

In the context of the state, its role in the socialisation process and their mutually conditioned impact on each other, it comes to the correlation of self-organisation and self-government with external governance which regulates and sets certain norms. The state has rather a significant impact on the content and conditions of socialisation. It establishes an order which is primary regarding the form of its presentation and implementation, but at the same time the state is derived from the society.

Having turned to the society based on market economy, the Ukrainian state was faced with the necessity to replace the former Soviet model of socialisation and state policy (with the active role of party and state power and clear programming of a set of features that the state wants to see in every person) with a new model of socialisation the specificity of which is individual responsibility, subsidiarity, self-realisation and adaptation to changes which happen.

But it should be remembered that one of the main factors which determines the process of socialisation is the nature of the relations between an individual and society or society and the state. The determination of the main tasks of socialisation depends on the place and role of an individual in the system of social and legal relations. The existence of contradictions between subjectively planned, although the most humane goals, and objectively existing social relations will certainly lead to negative consequences of the socialisation process. However, it should be noted that the question of the necessity for socialisation and state activities in this area for has remained for a long time controversial both among politicians and among scientists. There is a collision of mutually exclusive approaches: "for" socialisation and "against" it. 
The first of these approaches which is supported by supporters of the humanistic trend in sociology is based on the attempt to prove the danger and harmfulness of socialisation in general. It comes to "the drama of an individual" whose needs, according to Herbert Marcuse, the American sociologist and political scientist, "are being planed" although the determining factor should be "education of individual autonomy" [8]. An alternative approach, expressed by the representatives of structural functionalism, is to recognise the importance of socialisation as a means of maintaining social balance in the society, next to social control as a way to maintain the order among people.

Talcott Parsons, one of the representatives of this theory, in his analysis of socialisation proceeded from the fact that the nature of an individual is the demonstration of the specificity of social objects with which the connection is maintained during the life of this or that person when the determining role is played by cultural values and norms which are institutionalised in the social systems [9].

The integration of individuals into the social system is due to the interiorisation of generally accepted norms, when in the process of communication common values are combined with the other significant values. Thus, to his opinion, the social system and its constituent elements are reproduced, and socialisation is a way of maintaining the social balance in the society, along with social control which ensures the order in the society.

In addition to the above approaches to socialisation, it is appropriate to single out another third approach developed by Jurgen Habermas, a German scientist. It comes to so-called "critical theory of socialisation" which states that these processes cover only a part of an individual which reflects the social essence of an individual and his social character through which passes a normal life in the society. The other part of it, it seems, allows to "keep a kind of distance" in relation to the dominant system of roles, norms and values in the society.

This approach is implemented by the assertions that supposedly common for today in theory and practice understanding of socialisation prevents the personal formation of subjective self-identification and self-determination of a person as a socialised individual although the orienting point should be "the development of the ability to build and implement one's own life project" [10].

Thus, according to A. I. Kovaliova, "there is a possibility of a critical attitude" to the elements of the social environment which prevents a person from self-assertion [11]. But one way or another, the state, as one of the main institutions of legal socialisation of an individual, should ensure the harmonious interaction of all other institutions and agents. The activity of the state authorities regarding the implementation of the society's needs remains a subjective factor that fills the modern stage of socialisation with specifics. 
One should note that the strategic orientation of the state in this matter is the inclusion of socialisation itself in the society for qualitative ensuring an individual's needs.

On the other hand, the policy itself (with certain warnings) should be an important task for analysts and government officials responsible for developing the policy and consideration of the socialisation's needs. This confirms the functional role of socialisation in solving a wide range of socio-economic and socio-political problems. It is important when it comes to the current stage of development of the state social policy.

Thanks to a wide approach to socialisation, it is possible to focus on the interconnectedness of the processes that make up the essence of socialisation. Thus, an active role of the interconnections of the state with different social groups and different spheres of the society becomes clear.

Large-scale interpretation of socialisation allows on the one hand, to focus on the characteristics of this phenomenon which is a combination of purpose-oriented efforts made by the state, family, educational establishments, etc; on the other hand, it allows us to evaluate the socialising processes in the result of constant impact on the daily life of anindividual.

Socialisation is a complex social formation which in terms of scale and fundamental nature can be compared with social existence and substance. Socialisation should be a goal and the most important means of the state to solve socio-economic and political problems.

Considering socialisation as a component of the state's internal policy, there is a reason to believe that this concept covers a wide range of phenomena and processes. Taking into account the specifics and role of socialisation in various spheres of the society, we draw attention to the fact that socialisation is not just a process, but a certain coordinate system with a set of vectors.

Despite the fact that the state is a part of the society, due to sociological analysis it is possible to go beyond the state self-sufficiency to analyse the whole set of connections between the state and the society.

The state confers on and regulates social changes and social development, acting as the largest "factory for the production of social relations" in the society (as Herbert Spencer, one of the classics of world sociology, understood it).

However, for solving these problems one should take the state, first of all, as a social phenomenon determined by many factors. Understanding of different approaches to the essence of the state contributes to the specification of its ideas about it, namely: as "the authority that gives rights and imposes duties" [12], "concentration of power with certain boundaries" [13]. It comes to the state as a social institution and its capabilities. 
Herbert Spencer he called social institutions "factories for the production of social relations", and Emil Durkheim recognized sociology as the science of social institutions, their genesis and functioning, considering the state (political society) as the result of the interconnections of a large number of secondary social groups subordinated to the single center of power.

The state in the sociological sense is determined by the community of individuals and social groups that operate within the national-territorial boundaries [14;15].

The specificity of the sociological perception of statehood to a certain extent is determined by the socio-institutional components since the state is the most important institution of the society and consists of institutions.

Here one can note the role of the state (as an institution) and state authorities which lies in saving vital, universal values for all citizens, that is, sovereignty of the country, external and internal security, law and order, protection of nature, human rights and freedoms and peace and prosperity in the society.

\section{CONCLUSION}

So, let us determine the role of the state as a subject of socialisation. First, it is a conceptual framework imbued by the ideas of the state authorities about their citizens, recognition or on the contrary, non-recognition them as subjects of the state policy. Second, this is an act, activity and creative beginning of the state policy. Third, it is a managerial and ideological position. On the one hand, the content and conceptual foundation of the state policy in the sphere of socialisation is the responsibility of an individual for his destiny and for that of the state, and on the other hand, it is the responsibility of the state to ensure the conditions for self-determination of an individual through its socialisation. The essence of the state participation in the process of socialisation is less the declaration of the importance of the population as a strategic resource, plans (or even results) than as the relevant state position.

Despite the special importance of administrative and state-legal mechanisms and the fact that the state is the largest institutional entity, the political system of society is not limited to it. The state is a part of the society and its instrument that allows to talk about the state duty to create the conditions for the normal functioning of public institutions.

On this theoretical and methodological basis it becomes possible to fix the content and specificity of the state activity as a way of awareness and solution of a wide range of tasks of socio-political, economic and spiritual spheres of life by the state authorities. It comes to the constituent elements of the system of public administration (based on the separation of authorities between the legislative and executive powers) which includes the mechanism of management of the state social policy.

The executive power authorities, local self-government authorities, public associations and citizens who take part in solving the problems of the state domestic policy interact with this mechanism. 
The state regulation of socialisation is a more subtle instrument than the management and organising the work with the help of well-tested and well-known administrative methods. By and large, it comes to the indirect, indirect management of complex processes of stimulating the activity in the social direction of various political and legal entities.

What should be the character of the state impact on very subtle and sensitive socialisation processes to avoid governmentalisation of the sphere of socialisation, and together with this, lest it should be dangerous (value-based and organisational) vacuum in the direction of the state activity so that the state mechanism in this area should be effectively used?

The most justified is the increasing role of sociology in the institutional analysis of the socialisation of public policy. Since sociological knowledge makes the object of its attention sections of social reality that can not be studied with the help of induction, deduction, analogy and other socio-philosophical methods, in this case, the primary steps in understanding the socialisation of the society should be done with the help of mass questionnaires by methods of qualitative sociology.

The state should make the efforts to overcome conceptual uncertainty in order to make the right choice in favour of one or another socialisation model of social policy implementation (paternalistic or subsidiary or object-subject or activity-role) which is based on the modern vision of the national goals, priorities and humanistic ideals.

The significant changes in economic, political, legal and other spheres of public life have led to the relevant changes in the system of legal values, ideas and views. The transition to the market economy and building a legal state and civil society require additional legal socialisation of an individual in the result of which new social values should become the values of a certain individual.

According to O. L. Lvova, the existence of differences between the social and individual values of a person is the greatest basis that even the most fair and legal law can remain only a magnificent proclamation if its value of content and purpose do not coincide with the inner conviction of an individual and do not come to life in his mind. Due to this reason, great attention of the government agencies that create and apply the law, and scientists who study state-legal phenomena should be paid to the "link" of old, obsolete and invalid stereotypes that have still existed since the Soviet era, when man existed for the state. If this does not happen, all Ukraine's efforts to achieve the European standards will be in vain. One should change the style of thinking and views, to reavaluate the priorities in one's own mind before trying to understand and adopt new, effective and really valuable standards according to which the whole civilized world lives.

Now for the Ukrainian society it is proper a contradiction between the course of building a legal state and civil society and legal reality on the one hand, and on the other hand, the particularity of which is that the law has not yet become the basis of 
relations in our society; public authorities and their officials often ignore the rule of law, popular is so-called "telephone justice". They often adopt normative legal acts which contradict one other, one can notice the tendency of advantage of regulations over legislation that increases among the population the legal nihilism which is the obstacle of building a legal state.

At all levels of the state and society there is no awareness of where our society actually moves and on what principles this movement is based. Therefore, the issues of further development of legal awareness of the population, overcoming legal nihilism, meeting the needs of citizens in obtaining the knowledge of law and the formation of their respect for it should be solved at the state level. The state should create the conditions for socialisation and self-realisation of the society, thus really determining the incentives for real participation of people in public life as well as expand the social base of social transformation, cultural and economic reproduction. This is achieved thanks to the purpose-oriented and coordinated work of all state authorities when the society will feel their activities, positive changes and the fact that social values become constant, guaranteed and usual and the arbitrariness and subjectivism leave public administration.

\section{REFERENCES}

[1] Kudryavtsev, V. N., \& Kazimirchuk, V. P. (1995). Modern sociology of law. Moscow: Yurist.

[2] Parygin, B. D. (1971). Fundamentals of socio-psychological theory. Moscow: Mysl.

[3] Davydov, Yu.N., Kovalyova, M. S., \& Filippov, A. F. (1990). Contemporary Western Sociology: Dictionary. Moscow: Politidatelstvo.

[4] Kon, I. S. (1988). Child and Society: Historical and Ethnographic Perspective. Moscow: Nauka.

[5] Bell, D. (1999). The upcoming post-industrial society. Experience in social forecasting. Moscow: Akademiya.

[6] Shchegortsov, V. A. (1981). Sociology of legal consciousness. Moscow: Mysl.

[7] Koretsky, S. M. (2003). Criminological characteristic of deviant behavior of minors (Candidate thesis, National Academy of Internal Affairs of Ukraine, Kiev, Ukraine).

[8] Marcuse, G. (1994). One-dimensional man. The study of the ideology of a developed industrial society. Moscow: REFL-book.

[9] Parsons, T. (2000). On the structure of social action. Moscow: Nauka.

[10] Habermas, Y. (1992). Democracy. Mind. Morality. Moscow: Nauka.

[11] Zubok, Yu.A., \& Chuprov, V. I. (2008). Sociology of Youth. Encyclopedic Dictionary. Moscow: Academia.

[12] Claassen, L. V. (2002). New relations of power, citizens and politics. In L. V. Claassen (Ed.). Practical Guide to Protecting Interests and Civic Activism "Neighbors on the Planet". San Francisco - Washington: Asia Foundation.

[13] Selevko, A. G. (1999). The Great Intelligent Sociological Dictionary. Moscow: Veche-Act.

[14] Lvova, O. L. (2007). The right to live and active (on the value orientation of the right). The Journal of the Kyiv University of Law, 1, 11-17 
[15] Paraschevin, M. (2004). Social Solidarity in Ukrainian Society: Trends in Change. In V. Vorony, M. Shulga (Eds.), Ukrainian Society 1994-2004. Monitoring social change (pp. 448-458). Kyiv: Institute of Sociology of the National Academy of Sciences of Ukraine.

\section{Olga G. Koban}

Candidate of Juridical Sciences

Department of Theory of Law and State Assistant

Taras Shevchenko National University of Kyiv

01033, 60 Volodymyrska Str., Kyiv, Ukraine

Suggested Citation: Koban, O. G. (2019). Task of internal state activity in the socialization process. Journal of the National Academy of Legal Sciences of Ukraine, $26(1), 48-61$.

Submitted: $18 / 02 / 2019$

Revised: 25/03/2019

Accepted: 28/03/2019 


\title{
IHTEPHЕT-АIБЕРТАРІАНСТВО TA IHTЕРНЕТ-ЕТАТИЗМ В КОНТЕКСТI ІНТЕРНЕТ-ПРАВ АЮДИНИ
}

\begin{abstract}
Анотація. В роботі розглянуто проблему неузгодженості та дисбалансу між інтернет-лібертаріанством та інтернет-етатизмом з точки зору інтернет-прав людини. В роботі узагальнено протилежні фундаментальні позииії у питаннях балансу між правами і свободами людини та юридичними і фактичними можливостями державної влади щьодо контролю інтернет-простору та його суб'єктів. Автор пропонує власний стислий опис названих парадигм, надає очінку їхніх ключових ідей, пояснює їх на прикладах. Надана характеристика основних проявів дисбалансу між ичими парадигмами, щзо мали місце в останні роки. Виокремлено найбільш недискусійні, помірковані постулати інтернет-лібертаріанства та інтернет-етатизму, аналізуються точки зору деяких науковиів на досліджувані проблеми. Інтернет-лібертаріанство та інтернетпатерналізм - ие парадигми, щуо склалися в результаті дискусійного розгляду питання можливостей державної влади щодо контролю інтернет-простору та його суб 'єктів. Фундаментальні иінності, які репрезентуються циими парадигмами і ступінь втіленості яких на практиці залежить від балансу, - че свобода та безпека. В істотній залежності від вирішення иієї проблеми перебувають інтернет-права людини. Інтернетправа за своєю природою більше реалізуються через призму свободи, а інтернет-етатизм та інтернет-патерналізм є найбільшою загрозою для них. Однак, з іншого боку, необхідно визнати, щзо повноцінне існування інтернет-прав та користування ними потребує також і достатнього рівня безпеки в Інтернеті. Тому пошук балансу між вказаними парадигмами є вкрай необхідним для повноцінного функціонування екосистеми інтернет-прав людини. Пошуки балансу потребують виокремлення найбільш недискусійних, поміркованих постулатів інтернет-лібертаріанства та інтернет-етатизму, які можуть бути суміщені в інтегративному підході. На основі изього автор формулює пропозииії щуодо побудови врівноваженого підходу, за якого був би досягнутий баланс між забезпеченням інтернет-прав $і$ загальних прав людини та можливостями держави у сфері контролю елементів інфраструктури Інтернету.
\end{abstract}

Ключові слова: інтернет-права, інтернет-лібертаріанство, інтернет-етатизм, баланс. 
Andrii A. Kostenko

Department of Theory of Law and State

Taras Shevchenko National University of Kyiv

Kyiv, Ukraine

\title{
INTERNET-LIBERTARIANISM AND INTERNET-ETATISM IN THE CONTEXT OF THE INTERNET RIGHTS OF A PERSON
}

\begin{abstract}
The article gives a description of the problem of inconsistency and imbalance between the Internet-libertarianism and Internet-etatism in the context of the Internet rights of a person. The author generalises opposing fundamental positions on the matter of the balance between human rights and freedoms on the one hand and legal and factual capacities of the state authority to control the Internet space and its members on the other hand. The author's brief description of mentioned paradigms is given, the author evaluates their key ideas and describes them by using examples. The profile of the newest basic examples of imbalance between these paradigms is provided. The article includes the most indisputable and rational postulates of Internetlibertarianism and Internet-etatism. Relevant views of some scientists are analysed. On this basis, the author provides proposals for the creation of a well-adjusted approach whereby the balance between ensuring the Internet rights and common human rights on the one hand and state's capacities in the sphere of control of the Internet infrastructure elements, on the other hand, is possible.
\end{abstract}

Keywords liberty, safety, state, authority, balance.

\section{INTRODUCTION}

Seven years have already passed since the moment of recognising at the UN level the essential role of the Internet for the sphere of human rights and freedoms and, in particular, it was accentuated that the Internet provided people with the access to information and knowledge that had previously been inaccessible, and in such a way it made a significant contribution to the "discovery of the truth and the progress of the society as a whole" [1]. The continuous development of the Internet infrastructure all over the world and the improvement of the quality standards of access to the Internet demonstrate that the way to openness and access to the Internet for as many people as possible is an absolute priority of the civilised world. As of June 2018, about 55.1\% of the world's population has access to the Internet [2]. And this access should include not only the possibility of passive and contemplative stay on the Internet, but also a set of opportunities for every person to actively participate in all available Internet processes. An example is the right to develop one's own Internet resources [3]. The need for recognition and proper legal protection of the Internet rights of a person is evident in civilised legal systems. Besides, even the right of the whole cultures to be presented on the Internet is constituted [4]. The historical role of certain categories of the Internet resources (first all, social networks and messengers) continues to grow rapidly. One of the most outstanding examples of recent times is the well-known 
events related to the significant leakage of personal data on Facebook Social Network before and during the last presidential elections in the United States that probably had the purpose to affect the results of these elections [5]. At the same time, technological methods of fighting against criminality on the Internet are being improved, in particular, with certain Internet resources that in one way or another contribute to the criminal activity which obvious purpose is to ensure the security of the Internet space for everybody. However, at the same time, there is a growing threat to the Internet human rights (as well as the Internet freedom in general) from the authorities of individual states and their structures which receive direct or indirect access to such technological capabilities. The rationale of the research subject is due to the fact that the Internet functioning has significantly transformed and continues to transform both the private lives of people and economic, educational, cultural and even political processes. However, the Internet space, in some its part, remains vulnerable because pressure on it by interested government officials on the condition of getting the assistance to them from the side law enforcement agencies, courts and, in some cases, Internet providers and hosting providers creates comfortable conditions for the effective oppression of both sufficiently developed Internet resources and individuals who own them and / or who are their administrators.

The aim of the research is to carry out a cross-sectional analysis of directed ideals of freedom and controllability of the Internet space in the context of ensuring normal conditions for the implementation of the Internet rights of a person. However, one should develop and propose orienting points for a balanced correlation between the paradigms of Internet-libertarianism and Internet-etatism which are based on these ideals.

The matter of the balance between freedom and security (protection) in the Internet space was touched upon in the research works of such Ukrainian researchers as L. M. Novak-Kaliaieva [4; 6], A. M. Novytskyi, R. I. Radeiko [7] and A. O. Tlusta [8]. The problems of the state regulation of the Internet were investigated, in particular, by K. V. Stepanenko, Ye. V. Pischevska [9]. The problems of censorship on the Internet, among the others, were considered by T. M. Muzhanova [10], O. Riabokon [11] and the others. However, the controversial concepts of the state intervention in the Internet space, in particular, in the context of ensuring the Internet rights of a person, remain poorly investigated. The historical events in the field of legal regulation of the Internet in recent years which took place in Russia, China and some other countries are extremely indicative in the context of this problem and require a doctrinal evaluation.

\section{MATERIALS AND METHODS}

In the course of the research the methods of generalisation and analysis as well as method of synthesis for the formation of an integrative approach to the solution of 
the problem were used and some terms that were recently introduced into scientific use were applied. In this study they are understood as follows: 1) Internet rights are specific human capabilities the implementation of which is possible only in connection with the Internet functioning and mainly on the Internet (they were discussed in more detail in the previous research of the author [3]); 2) online is an adverb that means "on the Internet, in the Internet environment"; 3) offline is an adverb that means "outside the Internet" and the antonym of the term "online"; 4) content is electronic information of both a separate Internet resource and the Internet as a whole.

Also, one should note that the well-known term "Internet" in this research is used primarily as notation of the general information space of mankind to which a potentially unlimited number of people has access by connection to the technical global network of the same name. So, this term covers the information space formed on the basis of the most common "network of networks" which does not single (autonomous) local information networks of individual governments, educational establishments, industrial, military and other organisations. Also, it does not include permanent or temporary local computer networks created for private purposes and to which there is no access from any point of the "world Internet". Thus, human rights and freedoms mentioned in this research should be understood primarily as rights related to the direct participation and activity of a person in the world (world) Internet space.

\section{RESULTS AND DISCUSSION}

There are several informal but explicit paradigms of perception of the Internet in terms of the balance between, on the one hand, human rights and freedoms and, on the other hand, legal and actual possibilities of the government to control the Internet space and its subjects (hereinafter reffered to as "paradigms").

\subsection{Internet-libertarianism}

Since the introduction of the Internet in the world use there has begun to appear and develop a paradigm that can be called "Internet-libertarianism". It lies in the fact that the Internet, unlike traditional mass media (television, radio, press), has become a "zone of freedom" where every person, firstly, has a much greater choice of content for perception, and secondly, can independently create content and make it available for the other people around the world. That is, the Internet has eliminated numerous barriers (primarily psychological, economic and territorial) that did not give people the opportunity to get acquainted, communicate, gain new knowledge and spread their own experience in such an easy way. Thanks to the provided opportunities and unsurpassed properties, the Internet was started to be paid tribute. One of the most outstanding demonstrations of this in 1996 was the Cyberspace Independence Declaration (hereinafter reffered to as the CI Declaration). Its author, John Perry Barlow, for his strong position regarding the matter of the boundaries of government intervention in the Internet space was called a "cyberlibertarian" [12]. Undoubtedly, we 
should admit that the CI Declaration contains a lot of sharp statements that, at first sight, reduce its scientific value, but in its text it is still possible to identify several rational ideas:

- in the offline space, the state obtains authorities (power), as a rule, with the consent of the entities to which the exercise of such powers should be directed, whereas in the online space (namely, on the Internet) did not take place such socio-political processes, and therefore, one can not say that states have some power over the Internet users and can impose their own understanding of the Internet space development;

- for the representatives of the online space it is proper the ability of value and behavioral self-regulation and self-maintenance of order in the cyberspace that will be much more effective than external impact of the state, in particular, because of their awareness of the specifics of cyberspace because they are, relatively speaking, "on their territory" [13].

Although it is impossible to fully agree with such a statement. First, the mutual integration of online and offline spaces in terms of law means that, for example, the protection of a person from violence, discrimination, slander and other violations of his rights on the Internet should be no less principled and effective than in the traditional offline environment. It follows from this that law enforcement and human rights activity should be forcibly carried out in the Internet space, which in fact represents the intervention of the relevant authorities. These can be both long-standing intelligence agencies, and specially created authorities (e.g., cyber police). Second, relying on self-regulation and the maintenance of law and order by an indefinite number of private entities that had not previously undertaken to anything and whose results are not accountable to anyone is also largely unreliable. So, the principle "to be afraid of wolves means not go to the forest" as a warning to those people who are afraid of becoming a victim of arbitrariness on the Internet, in the civilised world does not work any more: The Internet is increasingly being controlled with the aim of ensuring the rule of law in the actions of different entities and guaranteed bringing law offenders to responsibility. However, of course, this should not mean the beginning of the Internet restructuring exceptionally in line with the vision of the government officials.

For the ecosystem of the Internet rights of a person, the Internet-libertarianism is a favourable paradigm because in the absence of any external restrictions and pressure, in particular, from the state, the best conditions are created for the free exercise of everyone's Internet rights.

\subsection{Internet-etatism}

Subsequently, with the increasing availability of the Internet around the world, it became clear that the Internet can be actively used for illegal purposes, with the task of real harm to people, enterprises and even entire groups of people, and in some cases the security of individual states. The examples of such use can include creation and implementation of different kinds of fraudulent schemes which are based mainly on 
the lack of sufficient technical knowledge of the majority of users; online trafficking in drugs, weapons and other objects the circulation of which is limited or prohibited; the spread of child pornography; committing hacker attacks and the spread of "computer viruses"; spread of misinformation and defamation (slander, insults, etc.); violation of personal data legislation; violation of intellectual property rights; incitement of intolerance and enmity in any sphere; coordination of terrorist activities and any other offences that can be committed using the Internet. Some criminal schemes and businesses can completely hide in the Internet space practically leaving no traces offline. Ye. Pischevska draws attention to the fact that "the Internet has caused the appearance of new forms of criminality" [9]. However, in our opinion, it is methodologically justified to say that the appearance and development of the Internet created the conditions for the appearance and development of these new forms of criminality since the Internet itself causes nothing and leads to nothing.

All this caused the expected chain reaction in political debates and legislative processes the final goal of which is creation of the secure Internet where human rights and freedoms as well as national security of the state should be protected no less effectively than offline. At first sight, only the state can take over responsibility for the systematic and responsible implementation of this activity, and that is the beginning of the story on how states increasingly understand the mechanisms of different elements of the Internet infrastructure and develop the measures to control the Internet at all levels has begun. That is the way the paradigm of Internet-etatism appeared and began to gain strength.

One of the most threatening tendencies in the development of the Internet-etatism is so-called "the Internet censorship". T. M. Muzhanova singles out three groups of methods of its implementation: technical, non-technical and indirect; a non-technical state can apply directly (for example, to create the necessary legal regulation) [10]. The researcher concludes that in the modern conditions censorship on the Internet is "widely used by the governments of many states and poses a direct threat to the basic interests of citizens in the field of information security" [10]. However, such a generalisation alone is not enough as there are different styles and forms of the Internet censorship. Thus, O. Riabokon singles out five censorship models: "Asian" (broad opportunities of the state and developed paternalism), "middle Eastern" (orientation to religious normsrestrictions), "monopoly of power on information" (fight against oppositionists and content of human rights defenders), "European" (fighting against socially dangerous resources and infringers of intellectual property rights) and "liberal" (fighting only with law violators blocking their resources) [11]. These models are generally listed in the manner of reduction of the social danger of censorship that makes it possible to draw the following conclusion: the "liberal" model, actually, is not censorship in the traditional sense. At the same time, these demonstrations are an indicator of the state's ability to authoritatively determine what kind of content should not be on the Internet and therefore, to intervene in the Internet space. 
For the Internet rights of a person the Internet-etatism (and in some cases the Internet-paternalism, as will be discussed below) is the biggest threat, especially in conditions where such rights are not legally enshrined, as in Ukraine. But even in case of entrenchment of such rights, the threat remains real and significant, taking into the specificity of the Internet space and individual Internet resources. For example, it is extremely difficult to make blocking an individual Internet resource proportional to the purpose of such blocking, and most often such blocking becomes unproportional that confirms the example of Roskomnadzor's activity in Russia in spring of 2018.

\subsection{Demonstration of imbalance between the paradigms}

The analysis of the ideas about the possibility of control of the Internet space by the state confirms that these paradigms are not compatible. They do not contradict one other at least in solving the matter of the extent of permissible state intervention in the Internet space functioning. For the Internet-libertarianism, such interference is either not allowed at all or is allowed only to the extent necessary for maintaining the normal functioning of the Internet itself, that is, the concept of the minimum necessary (forced) "evil". In this case, the conditional principle "The Internet is the territory of freedom outside the borders of any state and outside any state authority" is applied. On the contrary, according to the ideas of Internet-etatism, the nature of such an interference can be practically unlimited if it is necessary for the protection of an individual, society and state, national security, peace and any other values the protection of which is legally and factually entrusted to the state. The essence of the Internet-etatism is represented by the conditional principle, namely, "the power of the state on the Internet ends where the rights of its citizens protected by it end; where end the limit of whatever it is authorized to protect; where its own interest ends". Therefore, in practice, the Internet human rights under different paradigms will have different potential for the implementation. The imbalance between these two paradigms appears in several directions: value and applied.

As for the value direction, in the Internet-etatism, observing the practice of individual states, it is legitimate to single out such a subdirection as the Internet-paternalism. It comes to the situations where the state or its individual authorities, actually, are trying to fulfill the role of the father who carefully protects the Internet users from threats on the Internet. The examples of such care are the protection against pornography that "perverts"; protection against access to gambling and video games with elements of violence; protection from "unreliable" (opposition to the dominant ideology regarding political content; protection from "wrong ideas" and protection from "revolutionary news" (the last three examples are particularly evident in the Chinese segment of the Internet). So, in some cases the Internet-paternalism becomes an enemy of pluralism in both politicy and culture. The greatest "progress" in this field was achieved by such states as China, North Korea, Iran and some other states of the Middle East and Africa, mainly, with authoritarian governments and/or religious cul- 
tural context. To a some extent, Russia is on this way as well. Also, the demonstration of the Internet-paternalism can be called the cases as blocking by one state a social network or other Internet resources which are infrastructure is based in a state hostile to it and/or controlled by its representatives to protect their citizens from the enemy impact.

As for the applied direction, the Internet-statism is demonstrated in gradual acquiring the practical opportunities by the representatives of the state power: 1) initiation of effective completion of the process of blocking an Internet resource, web address or other means of "warning of receipt of certain content by the end user" [7]; 2) tracking technical events on the Internet at all levels or access to the specific data (data on the owner of the Internet resource for investigation purposes; details of the traffic of a particular consumer of the Internet services; data on the IP address from which the commentary was left through a special form on the news site, etc.). This, in particular, is connected with the so-called pressure on the Internet providers. The Internet providers, not wanting to lose their business which is now very promising, make concessions and cooperation with the government officials.

Also, the studied direction ensures the appropriate legal support of the opportunities provided to the state, that is, the adoption of appropriate legal acts which regulates the procedures for blocking the elements of the Internet infrastructure. Thus, in Ukraine, July 12, 2017 in Security and Defence Section there was registered a Draft Law on Amendments to Some Legislative Acts of Ukraine regarding countering threats to the national security in the information sphere (so-called Bill No. 6688) which is still under consideration. Apart from the claims about cybersecurity and the fight against terrorism set out in the explanatory memorandum which are well-known to the recent history of mankind, it is obvious that the main novelty of this bill is a significant expansion of the powers of the Ukrainian Security Service, some other authorities and entities (which carry out a pre-trial investigation) in relation to "extrajudicial blocking the Internet resources. Also, there is stipulated a new list of obligations and requirements for the Internet providers [14]. This bill has caused serious concern from the side of a large part of the domestic public including human rights defenders.

In the modern legal practice, appropriate technical conditions are being developed to identify the violations committed on the Internet and through the Internet, and establishment of identities of offenders on the basis of identification of the acts having signs of not only criminal acts, but also administrative and civil offenses. Beyond doubt, this is a positive trend because criminality in the wide sense, no matter where it takes place, online or offline, should be prosecuted and punished everywhere. However, one should remember that the fight against criminality should be carried out with the help of proportionate means, that is, without the risk of excessive collateral harm. In this context, destructive and counterproductive systematic attempts of Roskomnadzor to block Telegram messenger in Russia in spring of 2018 are very indicative which led to the 
malfunction of hundreds of web resources and services. These events led to a protest rally in Moscow of more than 12000 people [15], that, however, did not lead to any changes. So, the specificity of the Internet in combination with the modern achievements in the field of anonymisation of the Internet traffic significantly complicates blocking specially prepared online resources, and therefore, creates difficulties for supporters of the Internet-etatism as complete blocking such Internet resources requires the measures that definitely have no aim of such blocking. Consequently, such measures can be challenged in the court, human rights organisations and the like. In general, to be criticised from the standpoint of the rule of law, justice and reasonableness.

In our opinion, the opposite vectors of the paradigms of the Internet-libertarianism and Internet-etatism do not allow to find the balance within these paradigms themselves, and the solution to this problem requires the analysis at the theoretical and legal level. The result of such a decision should be a rational approach which would most appropriately combine the best demonstrations of the paradigms under consideration.

\subsection{Search of balance}

First of all, it is necessary to determine what postulates of the Internet-libertarianism and Internet-etatism we consider acceptable and what, in our opinion, representatives of both these paradigms could agree with. This is the first step towards the dialogue and cooperation between them.

The rational postulates of the Internet-libertarianism with which, in our opinion, it is impossible not to agree should include such as

1) it is necessary to preserve a free, open and decentralised basis of the Internet, that is, the qualities which significantly distinguish it from traditional media as well as make it a "weighted average", pluralistic, independent and distributed environment. The Internet would become the biggest threat to the society if it was centralised because, for example, provided to a successful hacker attack on the "center", the "periphery" would suffer as well;

2) any censorship or "pre-moderation" of the Internet (i.e., prior external evaluation and filtering the content before its publication) should be avoided. This is, among the other things, a direct threat to freedom of speech. The Internet, "like a library, should remain the place of freedom and openness which directly concerns the position and policy of the authorities in this matter" [6].

L. M. Novak-Kaliaieva draws attention to the fact that for the state authorities the prohibitions and penalties have always been "usual measures of impact" and have traditionally been considered effective in the context of implementation of tasks of counteraction to dangers and protection from the negative, however, these means are not effective in relation to the current scale of technological changes, and therefore, it is necessary to act by the methods that have nothing to do with violence in any form" [6, 
p. 72]. Indeed, the methods of action in the online world should take into account its elegance and complexity, but not just be a primitive reflection of similar actions offline. Thus, when Roskomnadzor, trying to block Telegram, stubbornly carried out the blocking of the entire groups of IP-addresses that disrupted the work of a number of web services of different scale and orientation which are no way related to this story [16], from the standpoint of cyberspace, this should be interpreted as real violence, as a kind of act of aggression.

The rational postulates of the Internet-etatism with which it is impossible not to agree include the following:

1) an individual and society should be protected from a crime wherever they can be present and where their rights and legitimate interests can be harmed. With the appearance of new spheres of life sooner or later in these areas, someone invented new ways to harm human rights and legitimate interests. Therefore, the state reacted to this and interpreted these actions in a legislative manner as criminal, administrative or other violations. At same time, the actual and legal means of fighting against criminality have been improved, the criminal procedural codes have evolved, and so on. This is the standard historical path "the appearance of new evil and the invention of new weapons to fight against it". History shows that the Internet should not be an exception in this respect, contributing to the rise of criminality within it.

2) a person who commits a violation in the Internet space (or with its help) should be identified and brought to legal responsibility in the way and to the extent that complies with the nature and severity of the violation committed by it, in particular, the harm done by it. So, for this task perfoming the authorised representatives of the state can take special measures that ensure the identification and tracking of such an entity in compliance with the procedures established by law.

As for the Internet-paternalism, we consider the following points positive and justified:

1) the need to protect children from the impact of content with the elements of excessive cruelty or sexual perversion which exceed the typical level of cruelty and sexual freedom proper to the culture of the society in which these children live;

2) the need to protect children from the impact of the specific Internet communities and subjects that promote and incite to risk, self-harm and suicide or otherwise do harm to the child's psyche as well as incite them to commit illegal actions.

In such cases, the child's implementation of his right to access and stay on the Internet in conditions of "effective" action of such negative factors objectively represents a greater threat to it than the positive result of the implementation of this right. In such conditions it is considered appropriate to insulate a child from such a threat until he reaches the age of majority when he should theoretically be able to adequately evaluate the reality and perceive such content with understanding. However, such 
insulation should not take the form of a ban on the Internet use until the age of majority (which is an example of imbalance, but already from the side of parents), content filtering systems have already been developed and and being improved ("parental control") as well as are the rules and mechanisms of social networks which aim to protect children from the dangers of this kind gradually being improved. In our opinion, from the theoretical and legal point of view, reaching the majority by a person should be understood as the moment when The Internet-paternalism regarding its moral and ethical development and the isolation from the dangers of the Internet should be reduced to a minimum level.

As for the matter of the state intervention in the Internet space in general cases which are not related to child protection, it is necessary to develop some doctrinal positions. Thus, L. M. Novak-Kaliaieva notes that "the state interference should be assistive" and that only subject to the detection of violations or the unwillingness of entities to act according to the generally accepted values of the Internet space the state can "motivate violators to adopt the state regulation based on the methods of transparency and frankness" [4]. However, the state regulation should comply with the values of both the Internet space and common sense. For example, if the law gives the representatives of the state authority the opportunity to significantly violate the Internet infrastructure functioning in a transparent (official) and procedurally correct, but unproportional way, the implementation of such a law will not mean that such assistive interference of the state complies with the ideas of balance, justice and reasonableness. The following position should also be taken into account: A. O. Tlusta considers it is an exaggeration to accuse social networks of generating protests and revolutionary movements, they are rather "just an information channel that serves the revolution, but does not cause it" [8]. Thus, one should not resort to the restriction of certain Internet resources only on the grounds that they are a means of communication for protesters because based on the same motives it would be possible to forbid any collective "calls" on the Internet, telephone communication, scientific conferences and so on.

\section{CONCLUSIONS}

Therefore, it is legitimate to propose the following constructive generalisations and proposals.

1. The Internet-libertarianism and the Internet-paternalism are the paradigms which have developed in the result of the debatable consideration of the possibilities of the state power to control the Internet space and its subjects. The fundamental values represented by these paradigms, which in practice depend on balance, are freedom and security. The Internet human rights are heavily dependent on the solution to this problem. The Internet rights by their nature are implemented to a larger extent through the 
prizm of freedom and Internet-etatism and Internet-paternalism are the greatest threat to them. However, on the other hand, one should admit that normal existence and use of the Internet rights also requires a sufficient level of security on the Internet. Therefore, the search of a balance between these paradigms is essential for the ecosystem's normal functioning of the Internet human rights.

2. The search of balance requires the identification of the most undiscussed and rational postulates of the Internet-libertarianism and the Internet-etatism which can be combined in the integrative approach.

2.1 The rational postulates of the Internet-libertarianism is the need to maintain decentralisation and openness of the Internet and avoid the Internet censorship in any form. The censorship on the Internet which should include pre-moderation and filtering is not a method of fighting against violations, but, in fact, a separate threat, in particular, for freedom of speech. Due to this we can raise the question of the need to classify the Internet censorship as such as a violation against the society. Therefore, the Internet censorship should not include the measures on blocking content that has been declared illegal in accordance with the procedures established by law. Regarding protection of children, filtering of unwanted content as a form of "user-side censorship" is a forced and justified means formed as the Internet-paternalism.

2.2 The rational postulates of the Internet-etatism are the need to prevent the transformation of the Internet into a hotbed of criminality and the need to ensure the inevitability of identification of an offender with further bringing him to responsibility for his own illegal actions (harm). It means that the state should be objectively endowed with the means and procedural capacities that enable it to achieve these goals. However, these procedures should be carried out in strict accordance with the ideas of proportionality.

3. The most generalised idea that combines both paradigms are the idea of proportionality of both legal and technical measures implemented by the state on the Internet, proportionality of their impact on the Internet space with the volume and importance of the historical tasks they solve.

\section{REFERENCES}

[1] Report of the Special Rapporteur on the promotion and protection of the right to freedom of opinion and expression. Frank La Rue (2011). United Nations, General Assembly. Retrieved from http://www2.ohchr.org/english/bodies/hrcouncil/docs/17session/ A. HRC.17.27_en.pdf

[2] Global Internet usage. Wikipedia.org. Retrieved from https://en.wikipedia.org/wiki/ Global_Internet_usage

[3] Kostenko, A. O. (2016). Contents and classification of human internet-rights. Paper presented at XIII International scientific and practical conference "Topical issues of 
reforming the legal system" (pp. 29-31). Lutsk: National University "Kyiv-Mohyla Academy".

[4] Novak-Kaliaieva, L. (2013). Global tendencies of solving the problems of human rights ensuring in cyberspace in the context of public administration tasks. Academic Papers Collection “Democratic Governance”, Issue 11. Retrieved from http://nbuv.gov.ua/UJRN/ DeVr_2013_11_5

[5] Revealed: 50 million Facebook profiles harvested for Cambridge Analytica in major data breach. (2018). The Guardian. Retrieved from https://www.theguardian.com/news/2018/ mar/17/cambridge-analytica-facebook-influence-us-election

[6] Novak-Kaliaieva, L. (2013). Modern algorithms of interaction of the state and society in the virtual space on the basis of the concept of human rights. Theory and Practice of Public Administration, 2 (41), 72-84.

[7] Radeiko, R. I. (2017, November). International practice of blocking access to information resources on the Internet. Paper presented at II International scientific and practical conference "IT Law: Problems and Prospects in Ukraine" (pp. 160-166). Lviv: National University "Lviv Polytechnic".

[8] Tlusta, A. O. (2012). The role of virtual communities in the deployment of revolutionary events in the world in 2010-2011. Actual problems of International Relations, 108(I), 136-142.

[9] Pishchevska, E. V. (2010). Internet in context of information security. Bulletin V. N. Karazin Kharkiv National University. "Political Science” Series, 17 (912), 152-157.

[10] Muzhanova, T. M. (2015). Internet censorship as a threat to the rights of citizens in the field of information security. Modern Information Protection, 2, 84-88.

[11] Riabokon, O. International experience of modern censorship and content filtering on the Internet. Retrieved from http://nbuviap.gov.ua/images/konferenciya/Ryabokon.pdf

[12] Goldsmith, J., Wu, T. (2006). Who Controls the Internet? Illusions of a Borderless World. Oxford University Press. Retrieved from http://cryptome.org/2013/01/aaron-swartz/WhoControls-Net.pdf

[13] Barlow, J. P. (1996, February 8). A Declaration of the Independence of Cyberspace. The Electronic Frontier Foundation. Retrieved from https://www.eff.org/cyberspaceindependence

[14] Draft Law on Amendments to Certain Legislative Acts of Ukraine on Combating National Security Threats in the Information Area (July 12, 2017, No. 6688). Rada.gov.ua Retrieved from: http://w1.c1.rada.gov.ua/pls/zweb2/webproc4_1?pf3511=62236

[15] Kod.ru. (2018). Roskomnadzor, block yourself! Retrieved from https://kod.ru/ roskomnadzor-siebie-zablokirui/

[16] Kod.ru. (2018). Consequences of telegram blocking. Retrieved from https://kod.ru/ posledstviya-blokirovki/

\section{Andrii A. Kostenko}

PhD Student

Department of Theory of Law and State

Faculty of Law

Taras Shevchenko National University of Kyiv

01601, 60 Volodymyrska Str., Kyiv, Ukraine 
Suggested Citation: Kostenko, A. A. (2019). Internet-libertarianism and internetetatism in the context of the internet rights of a person. Journal of the National Academy of Legal Sciences of Ukraine, 26 (1), 62-75.

Submitted: $17 / 01 / 2019$

Revised: $12 / 03 / 2019$

Accepted: 28/03/2019 
УДК 340.1

DOI: 10.31359/1993-0909-2019-26-1-76

Ольга Григорівна Варич

Кафедра теорї права та держави Київський національний університет ім. Тараса Шевченка

Київ, Україна

\section{РІВНІСТЬ, СВОБОДА, СПРАВЕДЛИВІСТЬ: ЦІННІСНО-ПРАВОВІ ВЛАСТИВОСТI}

Анотація. У статті досліджуються проблеми иіннісного підходу до розуміння важливих сочіальних пріоритетів, окреслюються ціннісно-правові властивості рівності, свободи та справедливості як основних підвалин ліберально-демократичних інститутів, основоположні засади побудови демократичного суспільства. Автором досліджуються еволюиійні прочеси розуміння правової рівності, свободи у праві та напрямки їх співвідношення як фундаментальних засад побудови сучасних векторів розвитку держави та права. Аксіологічний підхід загалом уособлює ставлення людини до об'єктивного предмета оцінки, до певного явища, вказуючи, як слід поставитися до ицього явища, як його використати, якщуо воно корисне, та уникнути - якщо шкідливе. Ціннісними критеріями у сфері права виступають його ідеали, в основі яких лежать визначені суспільні потреби та інтереси. Формування громадянського суспільства в Украӥні, входження Украӥни до європейського політико-правового простору можливі лише за умови засвоєння і втілення у життя фундаментальних демократичних изіностей, основою яких є рівність, свобода та справедливість. Ціннісноправові властивості рівності, свободи та справедливості мають бути зорієнтовані на європейську модель, адже ие визначальні пріоритети, еталони та ідеали завдяки яким відбувається природний прочес взаємодї влади та суспільства. Це те заради чого варто жити, існувати серед різноманітних соціальних груп у демократичному суспільстві, де панують рівність, свобода та справедливість. Свобода має два джерела - змістовне (природні права) і формальне (юридичні норми), тому правове регулювання полягає в ї̈ трансформуванні в юридичну сферу. Існують два основні шляхи досягнення рівності: забезпечення рівних можливостей; забезпечення рівних результатів. У зв'язку з ичи доцільно відзначати існування двох суттєвих аспектів рівності: рівність можливостей і рівність результатів. Автор пропонує власний опис зазначених парадигм, окреслює їх иіннісні основи та вектори змін в умовах сучасних глобалізаційних процесів.

Ключові слова: соціальні цінності, правові цінності, ціннісно-правові властивості, рівність, свобода, справедливість. 


\title{
Olha G. Varych
}

Department of Theory of Law and the State Taras Shevchenko National University of Kyiv

Kyiv, Ukraine

\section{EQUALITY, FREEDOM AND JUSTICE: VALUE-LEGAL PROPERTIES}

\begin{abstract}
The article investigates the problems of the value approach to understanding the important social priorities, determines the value-legal properties of equality, freedom and justice as the basic foundations of liberal-democratic institutions and fundamental principles of building a democratic society. The axiological aspect of law is the level of its compliance with such value categories as equality, freedom and justice. Correct understanding and regulation of the above categories are an important pre-condition of determining and solving a lot of practical matters, in particular, the ways of resurrecting the democratic and social state. The author investigates the evolutional processes of understanding of legal equality, freedom, in a right and directions of their correlation as fundamental principles of construction of modern vectors of development of the state and right. The author offers his own description of the above paradigms, outlines them the value bases and directions of changes in the conditions of the modern globalisation processes.
\end{abstract}

Keywords: social values, legal values, value-legal properties, equality, freedom, justice

\section{INTRODUCTION}

The development of the modern society, law and the state are associated with the constant processes of their value disorientation. In this direction the important aspect is the correct understanding and reglementation of equality, freedom and justice as necessary conditions for the development of the social state, the construction of value orientations in law and society. At the same time, value approach can not exist apart from a person because it is based on his needs and interests which are the foundation of its evaluations. Axiological approach generally represents the attitude of a person to the objective subject of evaluation, to a certain phenomenon, indicating how to treat this phenomenon, how to use it, if it is useful and avoid if it is harmful. Value criteria in the field of law are its ideals which are based on certain social needs and interests [1].

Values are the fundamental properties of culture, so the law should focus on the natural values of a person [2]. Legal values are the preconditions for the entry of an individual into the sphere of law. In the process of becoming familiar with the values of law, a person acquires the features of a subject of law, realises his rights, freedoms and duties. At the same time, the dualism of the axiosphere of the law of the modern society is determined by the fact that state-legal values ensure the integrity and stability of the society, and legal values of citizens are primarily aimed at the implementation 
of individual rights and freedoms. There occurs a so-called swing of the pendulum of value orientations from state-legal to individual values of freedom. The fever pitch of these value positions threaten the stability of the social system [3].

That is why the time when the world experiences the increase of aggression and significant spread of violent ways to solve socio-political problems, aspiration to develop the fundamental foundations of equality, freedom and justice which would be able to justify the moral-legal system of life values and priorities is quite natural and urgent.

The matter of axiological approach to the study of philosophical-legal phenomena was considered by O. O. Bandura [4; 5], V. S. Bihun [6], M. V. Kostytskyi [7] and the others. The problems of equality, freedom and justice as defining socio-legal values and principles were studied in the research works of A. M. Kolodiy [8], O. O. Bandura $[4 ; 5]$, O. P. Vasylchenko [9] and the others. The matters of complex analysis of the value-legal properties of equality, freedom and justice as the defining goal of building and developing social ideals require further research.

\section{MATERIALS AND METHODS}

The axiological approach which permeates the scientific-research strategy of the research is of great importance in the research work. This allows to imagine the subject of research through the prism of its value measurement, in particular, to establish the value orientations of law in the direction of clarifying the value-legal properties of equality, freedom and justice as an important component of the axiological essence of law. The anthropological approach makes it possible to consider the value features of equality, freedom and justice as natural and permanent properties of a person as a biosocial individual that serve as a measure of all things. The process of studying equality, freedom and justice implies the need to turn to the epistemological aspect of values since the process of their studying is based on the distinction between the objective and the subjective in the perception and implementation of equality, freedom and justice in the process of thinking.

In the process of scientific research, there was used the dialectical method which allows to trace the evolution of conceptual approaches to the matters of origin, development and formation of value orientations in the society, to find out the changes in the formation and development of legal values, in particular, to trace the vectors of value formation and evolution of equality, freedom and justice. The formal-dogmatic method allowed to investigate the normative aspects of the consolidation of the ideas of the value dimension of the categories of equality, freedom and justice. The paper also uses the methods of generalisation, analysis and synthesis of the formed conceptual positions concerning the problems of applying the axiological approach to studying the legal phenomena. Applying the comparative legal method allowed to compare and contrast the value-legal properties inherent to equality, freedom and justice. 


\section{RESULTS AND DISCUSSION}

\subsection{Vectors of development of the modern society's values}

The formation of the civil society in Ukraine and Ukraine's integration into the European political and legal space is possible only on condition of assimilation and implementation of fundamental democratic values the basis of which is equality, freedom and justice. These processes also actualise their theoretical analysis as basic social values and development goals of the Ukrainian society as an ideal [10]. Under this condition, the developing system of values can have a polyvariant character that is due to the natural needs and interests of individuals. Similar processes occur when it comes to the interaction of certain social institutions the highest degree of organisation of which is considered to be the state [11].

That is why, for a modern democratic society, Europe is becoming not so much a geographical concept but rather a value one. The European values constitute the basic foundations of the liberal democratic institutions of the Western European space which boundaries are not limited either to geographical features or belonging to the European part of the world. The values are the core of the culture of every nation, nationality and society. G. Hofstede, a modern researcher of values, is convinced that values are at the deepest level among the levers of decision-making because it is they that determine the ideological beliefs of individuals and the motivation of their actions. According to T. Parsons, a famous American sociologist, it is to the values that people turn for the final justification of their actions. The values go beyond specific situations that can be solved by an individual under the impact of interests and beliefs because they determine the main aims and meaning of life, that is why they are the most outstanding demonstration of an individual or society [12].

The core of the European values are liberal human rights and freedoms and democratic principles of building a law-governed and social state. The latter appeared as the principles of functioning of state and political institutions of the modern European countries and the European Union. In the modern science, value is a positive significance related to the interests of an individual, social groups and society. The importance of priority legal values is particularly acute in the need for their awareness by the representatives of the political elite: "We have something to stand together for, namely, for peace and freedom, for democracy and the rule of law, for equality, human rights and solidarity. All these European values are not just a promise. They laid down in the treaties and embodied in the legislation. These are the provisions on which we rely in our Republican worldview" [13].

That is why, the closest to the truth are the definitions of values which emphasise the ability of the phenomenon to be an aim and satisfy the interests and needs of people as well as serve social progress and personal development. Such understanding of value seems to us correct, moreover, such an approach to understanding of value is traditionally used in legal science [14]. 
The process of axiological understanding of law, state and society has recently acquired a global character. This is due to the penetration of legal values to the highest levels of the global value hierarchies. One of the fundamental values of an individual is the need for freedom. The latter, transforming into legal freedom, is able to overcome the "alienation" of a person in the field of law [9].

Freedom in interaction with justice and equality forms an axiological (value) basis of the law. Therefore, the law, determined and filled with universal orienting points and legal ideals, appears as an element of the common good, as a phenomenon of human coexistence.

However, one should note that freedom and justice only in their formal expression can, together with the principle of formal equality, enter into the concept of law and be components, properties and characteristics of law as a form, and therefore become the determining basis for the fundamental ideas of constitutionalism. Only within the framework of this approach, equality, freedom and justice can be interpreted as purely legal categories [15].

The Universal Declaration of Human Rights of 1948 established the formal basis of axiological properties of equality of freedom and justice and basic natural human rights at the international level. In this direction reasonable is the position of B. V. Malyshev who emphasises that by the above document for the first time at the global legal level it was suggested to all states of the world to recognise the system of fundamental human rights, to implement it in the national legal systems and ensure its protection and security. With the help of the Universal Declaration of Human Rights, the categories of "justice", "equality", "freedom" and "humanism" which are the aims of the moral and legal systems of social regulation received their universal legal consolidation and legal concretisation. Since then, the law has acquired a new, specific, fundamentally different from the morality of meaningful and effective means to achieve these aims [16].

The system of values performs the function of association of social groups, they determine the basis of their future existence and development. These values are not only a set of words, there is a connection between them, they complement and clarify one other. Some of them are the part of the system with its own significance, but in relation to other values obtain additional meaning.

\subsection{Value-legal properties of justice}

As it is known, law is a means of the society self-organising. The basis of this selforganising is the universal values (life, freedom, equality, justice, etc.) and it makes the law its own value. They have a principal meaning for understanding the essence of law. Studying these values leads to the conclusion that they are dialectically interconnected and form a certain system [17]. Justice has a special place in it. Social justice is not only the right distribution of products and benefits among people, but also the same opportunity to use social and political rights. Every person is invio- 
lable on the basis of justice which society should not violate in any case. Due to this, justice rejects the idea that the loss of freedom for some people can be justified by the greater good for the others. One should take into account the interests of all members of the society, but not just individual ones, albeit groups large in size. Therefore, in the democratic society, the constitutional freedoms of equal citizens are taken as political rights guaranteed by justice. Now the problem of justice as an important legal value for our country is particularly actual, as always on the steep fractures of history, in the situation where is a frontal reevaluation of the system of values. We have an idea about value foundations, and we should create a new system of values. Justice is one of the basic principles of law through which it is possible to create the conditions of security for citizens as well as it is reliable and guaranteed space for the activity of an individual [5].

Justice, as the basic legal value, has a determining role in understanding the law, construction of its institutions, formulation of the requirements for the legal regulation of relations in the modern society. Thus, the process of convergence of justice and law is a guarantee of the effectiveness of law, therefore and confirms its value as an effective social regulator [18].

In fact, the opinion of V. S. Nersesiants is of particular importance in this direction. "Justice is an internal property and the quality of the law, the category and characteristics of the legal character but not extra-legal". In his opinion, law is "always fair and is the bearer of justice in the social world. Moreover, it is law that is fair After all, justice is fair because, actually, it embodies and expresses universal legitimacy, namely, the essence and bases of the right, sense of the legal principle of the general equality and freedom" [19].

Ideals are necessary for people to delineate the vectors to them, to be orienting points and higher goals, to inspire and fill the life of other people and companies deep with spiritual meaning. The ideal of justice in law has always been attached great importance and justice was equated with law. It is known that in the Latin language law is denoted by the word "jus" which derives from "justiia", that is, "justice". The ancient Greeks believed that the principle of natural justice permeated the existence that means that everyone should live in accordance with this principle and this way harmony will be ensured in relations between people. A similar principle was laid in the basis of law by the ancient Romans. They called it aequitas, that is, the principle of fair equality or equal justice. The Roman lawyers believed that law is not aequitas, but strove to approach the ideal of justice. The principle of justice in law was developed by the European philosophical-legal thought according to the new realities of life in the era of the European modernity. However, this principle is one of the basic principles of the European legal humanism [20].

It is well known that everyone has his own idea of justice, everyone has his own truth and he has the right to protect it. Such an idea of justice arises from the unique 
nature of a person as well as unique conditions of his life and development. Such a view of justice can be justified from the moral standpoint, although in this perspective an extremely selfish position is unlikely to be justified, most likely, it will be condemned. In the moral dimension, it is especially important to maintain an equal measure and a balance in relations between people. Within the framework of natural law concepts, which always appeal to moral values and principles, the aim of justice is well traced - it demonstrates itself in maintaining an equal degree of balance in legal relations [20].

\subsection{Value-legal properties of freedom}

An important value-legal property of justice is its close interconnection with freedom as one of the key categories in the modern legal paradigm. Freedom, as a state of an individual, in the society is one of the controversial problems of legal science because it always belongs to the highest social and political-legal values. In this direction, based on historical and democratic principles one can distinguish three main posts of the modern value dimension: equality, freedom and justice [21]. At the same time, it is freedom that is given a crucial importance because it is of the highest value for both an individual and the society as a whole.

When considering the value-legal properties of "freedom" it is necessary to clearly trace its close interconnection with the law. The very value of law is related to its essential characteristics. It consists in the fact that the law is the embodiment of the idea of freedom, equality, tolerance, humanism and justice that actually constitute its essence. Directly as a phenomenon that opposes arbitrariness and lawlessness, at the same time, it provides space for ordered social freedom and activeness. Law has a significant place in the social life. In other words, in the ideal, law (the idea of law) is the value of ordered social freedom, justice and consensus.

Law is means of ensuring (guaranteeing) freedom and means of its restriction. On the one hand, it is in law that freedom gets its most concentrated expression in which it actually materialises, objectifies, exists in specific legal forms, principles and institutions. On the other hand, the law does not enshrine the absolute freedom of the entities of law, but only its specific measure which is objectively conditioned and determined taking into account the system of the relevant conceptual framework.

The law is a common scale for the implementation of freedom in the common life of people. The law does not eliminate all differences between different individuals due to their abilities and specific life circumstances, but only formalises and orders these distinctions on the only basis, fixing equal opportunities of getting these or those benefits, and providing them with the same legal procedure of the implementation for all. The value of law as a phenomenon which essence is justice is that it is both a means and a result of the search of a reasonable balance and proportionality between personal freedom and the common good", misconduct and punishment, costs (losses) and the acquisition. 
In the system of value-legal properties of freedom the doctrinal significance acquires the concept of legal freedom which determines not the framework of human behaviour, that is, one should do only what is stipulated by objective law, but the boundaries of freedom itself which is outlined by legal norms and which exists regardless of whether it is enshrined in the legislative way or not. In this direction, appropriate is the position of A. M. Kolodiy who notes that a person's freedom is his ability to act within the framework of the current legislation at his own discretion [8].

An individual's freedom is freedom within the limits outlined by the law and the Constitution of the state based on it. However, the principle of freedom applies to all subjects of legal relations including an individual and the state. The freedom of an individual is the ability to do anything that is not expressly prohibited by law". Unlike the freedom of an individual, the freedom of the state, its authorities and other subjects (legal entities under public law) consists in the possibility of doing only what is expressly stipulated by law". Besides, the state's sovereignty allows to speak about its freedom in the world community. The common feature between these freedoms is that none of them can be unlimited. The law provides not only "freedom for" - for vigorous activity and effective self-expression of an individual, but also "freedom from" - from restrictions and interference in the life activity of an individual [22].

Freedom in the form of vital interests of an individual acquires a certain meaning. And thanks to this, gets a reasonable basis to perform the role of a methodological orienting point for a legislator.

So, according to the analysis, freedom has two sources - substantive (natural rights) and formal (legal norms). That is why legal regulation consists in its transformation into the legal sphere.

Freedom, in the result of its special value to provide individuals with the opportunity to meet their diverse needs, is not able to be formed only from restrictions, that is, its primary source can not be the permission on the principle of "less freedom means more freedom". To ensure the freedom of everyone, one should determine and preserve the boundaries of the existing freedom, that is, the principle "from the disorder of freedom to its ordering" should operate. Thus, the determination of the freedom's boundaries is the identification of its content characteristic features which determine its boundaries. In this case, the legal determination of freedom is properly secured, that is, law not only determines the boundaries of an individual's possibility, but also enables him to preserve, protect and restore everything within the boundaries of his freedom. Law, being the most effective social regulator, determines these boundaries best. One should emphasise that characterising the designated value-legal property of freedom, law should not limit it, but, on the contrary, it should provide it with informative content. So, the aim of law is to determine and preserve freedom. At the same time, the value of law lies in the trinity of freedom, equality and justice. Therefore, the demand for equality is closely connected with the ideas of justice and freedom. 


\subsection{Value-legal properties of equality}

The problem of equality in law was and is the object of research of thinkers of all ages. Thus, at the general theoretical level, the doctrine of equality as a category of law was studied in the research works of such prominent ancient thinkers and philosophers as Socrates, Plato, Aristotle, Democritus, Marcus Aurelius, Seneca, etc, and such medieval thinkers as Thomas Aquinas, Niccolo Machiavelli, Thomas More and Tommaso Campanella. As a political and legal principle, equality was studied in the research works of almost all philosophers of Enlightenment - Voltaire, Rousseau as well as the representatives of the German classical philosophy - Kant, Hegel, the figures of the French Revolution and many others, in particular, Friedrich Nietzsche. Among the domestic prerevolutionary philosophers and scientists who developed the issues of equality in law, one should call, first of all, M. O. Berdiaiev, P. I. Novhorodtsev, I. Ya. Franko [23]. The disputes on the role of the category of equality in law and society are still ongoing.

At the current stage of legal science development a generally recognised is the thesis the main aim of which is that according to the essence of justice, human relations should be formed in the sense of equality. However, the concept of justice is not limited to the requirement of equality which forms only one of its aspects, namely, formal justice. One of the leading modern concepts is also the dilemma of "freedom against equality". Freedom and equality can coexist as both complementary and conflicting values. The character of relations between them is determined, first of all, by the concept of equality which is implemented in legal policy. However, the principle of "equality in freedom" should be the starting point in these relations. The requirement of a measure of freedom that is applied equally to everyone can be transformed into the following logical chain: freedom (in legal and social sense) - right (as a measure of freedom) equality (equal measure regarding everyone) [23].

Correct understanding, reglementation and singling out the priority value-legal properties of equality are a necessary condition for clarifying and solving many practical issues, in particular, the ways of development of a democratic and social state.

Equality is one of the thorny concepts of past and present legal thought. Equality is a concept that means the same position of people in the society, but has equal content in different historical periods. The concept of "equality of all people" means their equal personal dignity. In this sense, people are equal because they are individuals without regard to their race, gender, skin colour or beliefs. That is why we talk about equal rights of people - the rights that are natural and inalienable (for example, the right to life) as well as the rights guaranteed by the current legislation [24].

As one of the fundamental values of the modern society and law, equality is a necessary way of social existence of freedom as any other effective form of existence and expression of freedom in social interaction of people, except legal, is difficult to imag- 
ine [19]. This is due, in particular, to the fact that freedom, not being introduced into a single common measure determined by the mutual and equal restriction of freedom of all participants of social communication, will inevitably turn into lawlessness when its only guarantee is power which in this case actually can no longer guarantee anything, because there is always a real possibility of its suppression by an even greater force. So, formal equality is a basic and universal principle of legal regulation which comprehensively determines the content of the rule of law since it embodies the requirements both for the content of positive law and for the forms and methods of its establishment and protection. Besides, the principle of formal equality can be concretised in one or another life situation in the consistent system of formally determined rules of conduct, that is, legal norms (positive law) [25].

In the modern literature, there are generally two main ways to achieve equality: ensuring equal opportunities and equal results. In this regard, it is reasonable to note that there are two essential aspects of equality: equality of opportunities and equality of results. The equality of opportunities is the idea that every individual should be guaranteed the same chances to make progress in life. This idea was especially actively discussed in the era of bourgeois revolutions: it was expressed by the phrase "la carrere ouverte aux talents» (from French - a career open to talents) and concerned artificial barriers which required to be eliminated, having abolished all privileges and provided state assistance to ensure equal opportunities for everybody to have better conditions. So, for this type of equality, individual achievements are a priority based only on a person's abilities, but not on his origin, nationality, skin colour, religion, sex, etc., and ensuring free competition when everyone is on equal footing and plays by the same rules. The equality of results is the idea that the society and the state should guarantee equality of people through the redistribution of social benefits or the introduction of so-called positive discrimination. This type of equality is possible only provided that free competition, which is the basis of equality of opportunities, is restricted. Both of these aspects of equality are demonstrated in the sphere of legal regulation. Thus, the concept of equal opportunities is embodied primarily in the general legal principle of equality before the law [23].

\section{CONCLUSIONS}

Axiological approach generally represents the attitude of a person to the objective subject of evaluation, to a certain phenomenon, indicating how to treat this phenomenon, how to use it, if it is useful and avoid if it is harmful. The value criteria in the field of law are its ideals which are based on certain social needs and interests.

The formation of the civil society in Ukraine and Ukraine's integration into the European political and legal space is possible only on condition of assimilation and implementation of fundamental democratic values the basis of which is equality, freedom and justice. 
The European values constitute the basic foundations of the liberal democratic institutions of the Western European space which boundaries are not limited either to geographical features or belonging to the European part of the world. The values are the core of the culture of every nation, nationality and society.

Law is a means of society self-organising. The basis of this self-organising is universal values (life, freedom, equality, justice, etc.) which the law makes its own values. They are fundamental for understanding the essence of law. Studying these values leads to the conclusion that they are dialectically interconnected and form a certain system.

Justice, as the basic legal value, has a determining role in understanding the law, construction of its institutions, formulation of the requirements for the legal regulation of relations in the modern society. Thus, the process of convergence of justice and law is a guarantee of the effectiveness of law, therefore, it confirms its value as an effective social regulator.

Freedom has two sources - substantive (natural rights) and formal (legal norms), therefore, legal regulation consists in its transformation into the legal sphere.

There are two main ways to achieve equality: ensuring equal opportunities and ensuring equal results. In this regard, it is worth noting that there are two essential aspects of equality: equality of opportunities and equality of results.

The mentioned value-legal properties of equality, freedom and justice should be focused on the European model because these are the determining priorities, standards and ideals, thanks to which there is a natural process of interaction between the government and the society. This is what it is worth living for, to exist among different social groups in the democratic society where equality, freedom and justice prevail.

\section{REFERENCES}

[1] Nenovski, N. (1987). Pravo and values. Moscow: Progress.

[2] Babenko, A. (2002). Legal values and mastering their personality (Doctoral thesis, Academy of Management of the Ministry of Internal Affairs of Russia, Moscow, Russian Federation).

[3] Bandura, O. (2008). Osnovni the value of right as system. Law of Ukraine, 5, 14-19.

[4] Bandura, O. O. (2012). Justice and its role in the system of values of right. Law and Life. International Scientific and Practical Legal Journal, 10, 19-25.

[5] Bigun, V. S. (2003). A man is in a low. Legal lyudinorozuminnya as philosophical-legal problem. Problems of Philosophy of Law, 1, 126-128.

[6] Kostickiy, V. V. (2011). Bagatolike right. Teologo-sociological understanding of right and problem of the constitutional fixing of theory of distributing of power. Legal Bulletin of Ukraine, 36, 6.

[7] Kostytskiy, V. (2011). Many-sided right. Teologo-sociological understanding of right and problem of the constitutional fixing of theory of distributing of power. Legal Bulletin of Ukraine, 37, 6. 
[8] Kolodiy, A. M., Oprishko, I. V., \& Demskiy, S. E. (2000). Jurisprudence. Kiev: Yurinkom Inter.

[9] Vasilchenko, O. P. (2017). Equality of people and freedoms and justice: question of correlation and priority. Our Law, 1, 27-33.

[10] Dzeban, O. P., \& Manuylov, E. M. Informative safety in the context of informative culture. Retrieved from http://ippi.org.ua/dzoban-op-manuilov- ${ }^{\circ} \mathrm{m}$-informatsiina-bezpeka-vkonteksti-informatsiinoi-kulturi-st-74-81

[11] Savchin, M. (2010). Constitutional values and constitutional jurisprudence in Ukraine. Bulletin of the Constitutional Court of Ukraine, 1, 111-120.

[12] Amelchenko, N. Concepts of Obedience of Europe. Retrieved from www.parlament.org.ua

[13] Trembin, M. P. Philosophy of legal education in Ukraine: directions and prospects. Retrieved from www.eprints.kname.edu.ua

[14] Kartashov, V. N. (1989). Legal activity: concept, structure. Saratov: Publishing House of Saratov University.

[15] Grafskiy, V. G., Dozhdev, D. V., \& Efremov, N. N. (2000). Politiko-pravovye values and contemporaneity. Moscow: Enditorial.

[16] Malishev, B. V. (2012). General declaration of human of 1948 rights and modern pravorozuminnya. Bulletin of the High Council of Justice, 3 (11), 147-160.

[17] Donchenko, O. P. (2008). Axiological content of the category of freedom in law: the relationship of the principles of freedom, equality and justice. Actual Problems of State and Law, 40, 69-74.

[18] Dobosh, Z. (2016). Justice in the philosophical and legal thought of modern times. Bulletin of Lviv Polytechnic National University. Law Sciences Announcer of the National University "Lviv Politekhnika". Legal Sciences, 855, 389-397.

[19] Nersesyanc, V. S. (2006). Philosophy of Law. Moscow: Norm.

[20] Patey-Bratasyuk, M. G. Anthropocentric theory of law. Kyiv: Tsentr uchbovoyi literatury.

[21] The notion of equality in the philosophy of law. Retrieved from http://www.philosophylawdep.chnu.edu.ua/professors/files/publications/serhiy_bodnar/06.pdf

[22] Krusyan, A. (2010). Modern Ukrainian constitutionalism. Kyiv: Yurinkom Inter.

[23] Pogrebnyak, S. (2006). Vtilennya to principle of equality in legal acts. Bulletin of the Academy of Legal Sciences of Ukraine, 3, 8-19.

[24] Gusak, P. (2016). Freedom-equality-justice: a question of values is in sekulyarnomu society. Retrieved from http://dc.lviv.ua/bbloteka

[25] Levickiy, O. (2014). philosophical-legal ideas of equality and justice in the process of pravotvorennya. Scientific and Information Bulletin of Ivano-Frankivsk University named after King Danylo Galychina, 9, 117-120.

\section{Olha G. Varych}

Candidate of Legal Sciences, Associate Professor

Associate Professor of Department of Theory of Law and the State

Taras Shevchenko National University of Kyiv

01033, 60 Volodymyrska Str., Kyiv, Ukraine 
Suggested Citation: Varych, O. G. (2019). Equality, freedom, justice: valued-legal properties. Journal of the National Academy of Legal Sciences of Ukraine, 26 (1), $76-88$.

Submitted: 29/01/2019

Revised: 19/03/2019

Accepted: 28/03/2019 
УДК 343.63

DOI: 10.31359/1993-0909-2019-26-1-89

Віктор Климович Грищук

Відділ організаиії наукової роботи

Львівський державний університет внутрішніх справ Аьвів, Україна

\title{
ЕФЕКТИВНІСТЬ \\ КРИМІНАЛЬНО-ПРАВОВОГО ЗАБЕЗПЕЧЕННЯ ОХОРОНИ І ЗАХИСТУ ГІДНОСТІ В УКРАЇНІ: ПИТАННЯ СОЦІАЛЬНОÏ ЗУМОВЛЕНОСТІ
}

\begin{abstract}
Анотація. У статті здійснено спробу дослідження ефективності кримінально-правового забезпечення охорони $і$ захисту гідності в Украӥні. Вирішення такої проблеми стало можливим через звернення уваги на питання соціальної обумовленості криміналізації діянь, які посягають на гідність людини. Важливим є те, щуо автором встановлено чинники соціальної зумовленості криміналізацї таких діянь. Особливу увагу було приділено необхідності криміналізації в Україні образи та наклепу як злочинів проти гідності особи. Такий висновок автором було зроблено через аналіз національного, іноземного та міжнародного законодавства. Проведений вище аналіз чинників дає підстави для висновку про наявність сочіальної зумовленості для встановлення кримінальної відповідальності за такі посягання на гідність людини як наклеп та образа, щзо істотно підвищить ефективність забезпечення правової охорони та захисту гідності людини, сприятиме подальшому утвердженню ї̈ прав і свобод на шляху євроінтеграчії України. Не зважаючи на те, що честь та гідність людини названі в ст. 3 Конституції України серед благ людини, які визнаються найвищими соціальними цінностями в Україні, а в назві третього розділу Особливої частини КК є слова «честь» $i$ «гідність», в изьому розділі таких складів злочинів немає. Крім ияього, на відміну від попередніх кримінальних кодексів, появилося в його назві слово «честь», застосування якого видається некоректним щуодо наведеного вище сучасного розуміння гідності людини в доктрині філософії права та теорії права. Отже, назва изього розділу ширша за ії зміст, кримінальна відповідальність за посягання на згадані изінності відсутня. Автором вказано на наявність соиіальної зумовленості для встановлення кримінальної відповідальності за такі посягання на гідність людини як наклеп та образа, щзо істотно підвищить ефективність забезпечення правової охорони та захисту гідності людини, сприятиме подальшому утвердженню ї̈ прав і свобод на шляху євроінтеграції України.
\end{abstract}

Ключові слова: злочини проти гідності, соціальна зумовленість, ефективність кримінально-правового забезпечення охорони гідності, дифамація, образа, наклеп. 
Viktor K. Hryshchuk

Department of Scientific Work Organization Lviv State University of Internal Affairs

Lviv, Ukraine

\title{
EFFECTIVENESS OF CRIMINAL LAW SUPPORT OF DIGNITY PROTECTION AND SECURITY IN UKRAINE: QUESTIONS OF SOCIAL CONDITIONALITY
}

\begin{abstract}
The article attempts to study the effectiveness of criminal law support of dignity protection and security in Ukraine. The solution of such a problem was made possible by paying attention to the questions of the social conditionality of the criminalization of acts that infringe upon human dignity. It is important that the author established the factors of social conditionality of the criminalization of such acts. Particular attention was paid to the need for criminalization of insult and slander as a crime against the dignity of the individual in Ukraine. Such a solution to the problem was made possible by the study of national, foreign and international legislation. The author has established the existence of social conditionality to establish criminal liability for such encroachment on human dignity such as slander and insult, which will significantly increase the effectiveness of legal protection and protection of human dignity, and will also contribute to the further assertion of rights and freedoms towards Ukraine's European integration.
\end{abstract}

Keywords: crimes against dignity, social conditionality, effectiveness of criminal law ensuring the protection of dignity, defamation, insult, slander.

\section{INTRODUCTION}

In legal literature, when analyzing criminal law problems, the term "guard" and "protection" is commonly used, although the etymological content of them seems to be different. "Guard" means to protect from the danger someone, anything, from the threat of attack (encroachment - VK), an attempt, to guarantee the inviolability of someone, something. "Protect" - to defend, to protect someone, anything from attack, assault, blow, hostile, dangerous, etc. actions [1]. The difference between them is that the concept of "protect" reflects the statics of social relations, provided by the rules of material criminal law. These norms contain the command, volitional regulations of the state, expressed in models of the corresponding behavior of the subject in a concrete situation: a prohibition, duty, permission (granting of right), promotion, exercising the same protective function of criminal law [2]. The concept of "protect" reflects the dynamics of social relations, when a person performs the corresponding criminally wrongful act. For example, preparing for a crime, attempting an offense or completing a criminal offense [3]. This is the implementation of a legislative model of command, a voluntary prescription on the behavior of the subject in a specifically defined situation. In the above cases, the rules of substantive criminal law, figuratively speaking, "come alive", and are applied by the competent authorities of the state. In this version, in addition to the rules of substantive criminal law, criminal procedure 
norms are applied, and further - the rules of criminal executive [4]. One more thing, in the case of a person's conviction, the rules of administrative law are applied. In general, in this option, the regulatory function of criminal law is exercised concerning relations that arise between a person who commits or has committed an offense and a state represented by its competent authorities. Therefore, the effectiveness of criminal law protection and protection of human dignity must be carried out qualitatively at both levels, each of which has its own specifics.

Specialist in the field of criminal law O. Protynyak [5], N. Savinova [6], O. Hramtsov [7] and others addressed the problem of guard legal enforcement and protection of human dignity. At the same time, these studies are not sufficient to establish the effectiveness of criminal law enforcement of guard and protection of dignity in Ukraine, as well as to address the issues of social conditionality.

The purpose of the article is to establish the effectiveness of criminal law enforcement of guard and protection of dignity in Ukraine through studying issues of social conditionality.

\section{MATERIALS AND METHODS}

The system of positive (effective) law of the state should contain comprehensive legal guaranteed of human dignity based on international law. Providing of the protection and the guard of human dignity is systemic, if all elements of the legal system are involved in harmony. In this regard, the situation in Ukraine not all guarding and protecting rights to maximize effective enforcement of human dignity are fully exploited. Without proper scientific substantiation, the civil law means are considered the main in the guard and protection of human dignity. At the same time, the question about social conditionality of criminal law guard and protection of human dignity arises.

The metrological significance of event causation of social phenomena has the categories of objective and subjective factors. In the broadest sense, the objective factor includes historical preconditions, interethnic and interstate relations, natural conditions, existing social relations and connections between people. In human activity, such components of the objective factor as politics, law, interethnic and external interstate relations, the state of objects of nature may be involved. All of them are interconnected and interdependent.

The socio-political and spiritual activity of people forms the component of subjective factor. Generally, definitive factors of it are moral, emotional-psychological and ideological factors [8]. All components of consciousness are involved in the structure of the subjective factor. Purposeful and systematic activity of people makes them a driving force. In the mechanism of action of the subjective factor, not only humans' conscious activity is involved, but also spontaneous manifestations of human abilities and passions. In such organic and harmonious combination, objective and subjective factors manifest themselves as dialectically contradictory and inextricably interacting 
sides of the phenomena of social development. Fully these general approaches are inherent in the activities of finding out the social conditionality of criminalization such acts against human dignity as slander and insult.

\section{RESULTS AND DISCUSSION}

\subsection{Factors of social conditionality of criminalization of acts that violate human dignity}

The scientific study of the complex of long-standing problems of the social conditionality of criminal law guard and protection of human dignity, as well as any other socially significant values, gives, first of all, the answer to the question if there are social circumstances (factors) that confirm the necessity of prohibition of slander and insults under the threat of punishment, and if so, what should be the theoretical and applied model of the norm (norms) of the law on criminal liability.

In the doctrine of criminal law, there is no generally accepted understanding of the circumstances leading to the criminalization of human actions. They are called differently, in particular: grounds, principles, criteria, conditions, reasons; grounds and principles; prerequisites and grounds, factors, etc. There are reasons to think that they should be called factors (circumstances) that predetermine the criminalization of certain socially dangerous acts, that is, criminal liability for these acts performance [9].

Regarding the social conditionality of criminalization of acts that violate human dignity, in particular slander and insult, the following are the most significant factors: 1) the social danger of acts that encroach human dignity; 2) the relative prevalence of these encroachments; 3 ) the expediency of counteracting this encroachment by means of criminal law; 4) the coherence of their criminalization with the norms of international law; 5) the conformity of their criminalization with the Constitution of Ukraine; 6) legislative practice to counteract this encroachment in European states; 7) traditions of the Ukrainian legislative practice to counteract this encroachment..

The public danger of encroachments on human dignity, their prevalence manifested itself especially during the period of the hybrid war against Ukraine. In the mass media, for example, so-called fake, false information, which contains defamatory, offensive attacks against the President of Ukraine, the Prime Minister of Ukraine, ministers, other public officials is systematically and purposefully distributed in order to undermine their authority in the eyes of the public, to weaken the belief in the effectiveness of the social reforms being implemented and in the European future of Ukraine. Slander and insult have become commonplace means of sorting out the relations between politicians of different levels, the realization of a competitive confrontation between business entities in the economic sphere, the construction of accounts between individual citizens in the service relationships and at the domestic level. Apparently, the limits of normative freedom in the information sphere are unjustifiably wide, it lacks righteousness [10]. All this undermines the normal, civilized moral and psychological state of social relations, promotes the implementation of hostile technologies to weak- 
en the Ukrainian state and society. Given the above circumstances, as an attack on human dignity slander and insult are an increased public danger.

The expediency of counteractions to slander and the insult by criminal means is obvious, since the application of only civilian remedies is clearly insufficient, both for the general and for the special prevention of their commitment.

The criminalization of slander and insult is consistent with the norms of international law, the Constitution of Ukraine, the legislative practice of counteracting these attacks in European states, the traditions of Ukrainian historical legal practice.

\subsection{Human dignity under protection of national, interethnic and international regula- tory legal acts}

In international law, human dignity has been an object of protection for a long time. In international law, human dignity has been the subject of protection for a long time. Thus, in the Universal Declaration of Human Rights (1948) there has been a repeated appeal to the dignity of human. In particular, its preamble proclaimed that recognition of human dignity is the foundation of freedom, justice and universal peace throughout the world; and article 1 states that all people are born free and equal in dignity and rights. According to article 5 of the declaration, no one should be subjected to torture or cruel, inhuman or degrading treatment or punishment. The principled provisions on human dignity have also been consolidated in the European Convention for the Protection of Human Rights and Fundamental Freedoms (1950), the OSCE legal acts; and they were specified, clarified in the decisions of the European Court of Human Rights.

In the International Covenants on Civil and Political Rights and on Economic, Social and Cultural Rights (1966), it has been stated, in particular, that all rights derive from the dignity inherent to a human.

A new confirmation of international legal protection of human dignity was the Charter of the European Union (2000). In Article 1, it is unequivocally proclaimed that human dignity is untouchable; it must be respected and protected. Consequently, there are grounds to claim that, in international law, human dignity is a source of human rights, a black letter law, and this must be taken into account when developing legislative mechanisms to ensure the protection of its untouchability in Ukraine.

The Constitution of Ukraine organically embodies all the achievements of international legal science and practice in protecting human dignity. The key is article 3 , which proclaims that human dignity belongs to the highest social values. According to the Constitution, all people are free and equal in their dignity and rights (article 21), every person has the right to respect for his dignity (article 28), the use of property cannot prejudice the rights, freedoms and dignity of a person; the duty of everyone is not to encroach the rights and freedoms, honor and dignity of others (article 68). Consequently, the above provisions of the Constitution, including criminal law, as the main 
law of the state, serve as a legal basis for the comprehensive guard and protection of human dignity $[11 ; 12]$.

An important precondition for Ukraine's integration into the European Union is to harmonize Ukrainian legislation and to bring it to European standards. A lot has been made, however, the European legislation on the guard and protection of human dignity by means of criminal law has not been noticed in a proper way. For instance, Germany Criminal Code provides for liability, in particular, for the offense of Federal President (paragraph 90), the offense (paragraph 185), the defamation (paragraph 186), discredit (paragraph 187), defamation or discredit against politicians (paragraph 188), the offense of honor of the dead (paragraph 189); the Dutch - for the offense (paragraph 266b, 267), the defamation (paragraph 266c, 267a, 268-275); the Swiss - for the offense (paragraph 177), the defamation (paragraph 173,174), the offense of honor of the dead (paragraph 175); Sweden - for the offense (paragraph 3), the defamation (paragraph 1.2), the offense of honor of the dead (paragraph 4); Spain - for the offense (paragraphs 209-210), the defamation (paragraphs 206-207); Austria - for the offense (paragraph 115), the defamation (paragraph 111), the public insult of a constitutional representative body, federal armed forces, a federal body (paragraph 116); Poland - for the offense (article 216), the insult to religious feelings (article 196), the public insult of a person or group of persons in connection with their national, ethnic, racial or religious affiliation (paragraph 196), the insult of the Polish people or the Republic of Poland (article 133 ), the public insult of the President (paragraph 2 of article 135); France - for the ridicule in order to violate the dignity of human (paragraph 226-4-1), the offense of a person who is in the public service (paragraph 433-5). Attention is drawn to the fact that the Criminal Code is not the only source of French criminal law. In addition, other French laws provide criminal liability. Thus, the Freedom of the Press Act provides for criminal liability for insult and defamation (chapter 4 of the Law). In particular, in accordance with paragraph 26 of this Law, the offense of the President of France is punishable by imprisonment for a term of three months to one year and a fine of 300 to 300 thousand francs [13].

The above selective analysis of the legislative criminal law practice of European states proves the expediency of using norms of criminal law for the guard and protection of human dignity.

Criminal law means of guard and protection of human dignity is inherit in historical legislative practice of Ukraine [14]. In the Soviet period, three criminal codes were in force; they provided liability for such encroachments upon human dignity as slander and insult. Thus, in chapter 5 of USSR Criminal Code of 1922 "Crimes against human life, health, will and dignity" there are following types of crime: insult by action, word or in written (article 172); insult in widespread or publicly displayed printed works or images (article 168), defamation as an essential element of a crime and libel in printed or spread in other way (article 169) - aggravating circumstances. USSR 
Criminal Code also provided liability for such actions. In the section 3 of its Special part "Crimes against human life, health, will and dignity" there are also two types of crime: 1) defamation as an essential element of a crime, its aggravating circumstance is in printed or spread in other way, in anonymous letter, as well as committed by the person previously convicted for such actions, especially its aggravating circumstance - defamation combined with accusation in state crime or other severe crimes (article 125); 2) offense (article 126).

\section{CONCLUSIONS}

Latest codification of criminal legislation, in conditions of independence of Ukraine, was marked with the sign of democratization, humanization, and intensification of human rights. It completed the process of bringing criminal law norms to the ripen interests and necessities of social development, made them qualitive effective guardian tool and regulation of social relations with the ability to develop. Criminal Code of 2001 turned out to be of a new, higher order. After becoming an objective reality it has acquired a status of priority object of scientific research, in the process of which its most important positive characteristics, discussion approaches were determined. In particular, attention was paid to a certain lack, incompleteness of system-forming connections between the Criminal Code and the Constitution, that is, it refers to criminal law and protection of human dignity. Thus, despite the fact that the honor and dignity of human are named in Article 3 of the Constitution of Ukraine as the human goods, which are the highest social values in Ukraine, and in the title of the third section of the Special Part of the Criminal Code there are the words "honor" and "dignity", there are no such crimes in this section. In addition, unlike the previous criminal codes, the word "honor" appeared in its name, but the use of it appears to be incorrect in relation to the above-mentioned modern understanding of human dignity in the doctrine of the philosophy of law and the theory of law. Consequently, the title of this section is wider in its content; there is no criminal responsibility for encroachments on these goods.

It should be noted that human dignity, in cases when it is recognized as a victim, is an additional object of the corresponding crimes. For example, crimes against life and health, the will of a person, crimes against sexual freedom and sexual integrity of a person, crimes against property, etc. It is also necessary to draw attention to the fact that a person with high prosocial attitudes can perceive any crime as an attack on her dignity.

The above analysis of the factors gives grounds for the conclusion that there is a social conditionality for establishing criminal liability for such attacks on human dignity as slander and insult, which will significantly increase the efficiency of ensuring legal guard and protection of human dignity, will contribute to further consolidation of its rights and freedoms on the way of European integration of Ukraine . 


\section{REFERENCES}

[1] Busel, T. (2009). Big explanatory dictionary of contemporary Ukrainian (with addition, and CD). Kyiv, Irpin: ATP "Perun".

[2] Arazan, C. L. (2018). Minority threat, community disadvantage and sentencing. Journal of Criminological Research, Policy and Practice, 4(4), 213-225.

[3] Kotecha, B. (2018). The art of rhetoric: Perceptions of the international criminal court and legalism. Leiden Journal of International Law, 31(4), 939-962.

[4] Ratliff, A., \& Willins, M. (2018). Criminal defense-based forensic social work. Criminal Defense-Based Forensic Social Work. Denver: University of Denver.

[5] Protinyak, O. M. (2011). Responsibility for defamation in the law of foreign countries and Ukraine. In Ukraine in the system of global information exchange: theoretical and methodological aspects of research and training of specialists. Materials Ukrainian scientific conference. Lviv: Lviv. Polytechnic.

[6] Savinova, N. (2014). On the social conditionality of the criminalization of information expansion in the conditions of the development of an information society. Legal Journal, $1,48-53$.

[7] Khramtsov, O. M. (2003). Criminology of verbal aggression (Candidate thesis, National University of Ministry of Internal Affairs, Kharkiv, Ukraine).

[8] Borisov, V. I. (2018) Crimes against the will, honor and dignity of the individual. Crimes against sexual liberty and sexual integrity. Kharkiv: Pravo.

[9] Franks, Q. (2018). Criminal justice: Government policies and programs. New York: Nova Science Publishers.

[10] Hryshchuk, V. K. (2010). Selected scientific works. Lviv: Lviv State University of Internal Affairs.

[11] Öberg, J. (2018). The legal basis for EU criminal law harmonisation: A question of federalism? European Law Review, 43(3), 366-393.

[12] Hryshchuk, V. K. (2002) Issues of the system of criminal-legal protection of a person under the new Criminal Code of Ukraine. In New Criminal Code of Ukraine: the question of application and study. Materials of the International Scientific and Practical Conference. (pp. 112-113). Kyiv, Kharkiv: Yurinkom Inter.

[13] Pavlykivskiy, V. I. (2015) Criminal libility for defamation (european approach). Law and Society, 2, 15-18.

[14] Pidhorodynskyi, V. (2016). Legal and criminal legal influence for defamation: different sides and questions of perfection. In O. V. Kozachenko, Ye. L. Streltsov (Eds.). Legal influence for illegal activity: topical sides. Mykolaiv: Ilion.

\section{Viktor K. Hryshchuk}

Doctor of Law, Professor, Senior Staff Scientist

Associate Member of National Academy of Law Sciences

61024, 70 Pushkinskaya Str., Kharkiv, Ukraine

Department of Scientific Work Organization

Lviv State University of Internal Affairs

79007, 26, Horodotska Str., Lviv, Ukraine 
Suggested Citation: Hryshchuk, V. K. (2019). Effectiveness of criminal law support of dignity protection and security in Ukraine: questions of social conditionality. Journal of the National Academy of Legal Sciences of Ukraine, 26 (1), 89-97.

Submitted: $12 / 02 / 2019$

Revised: $11 / 03 / 2019$

Accepted: 28/03/2019 
Школа права факультету бізнесу та управління Талліннський технічний університет Таллінн, Естонія

Володимир Андрійович Журавель Національна академія правових наук України Харків, Україна

\section{ОКРЕМІ КРИМІНАЛІСТИЧНІ ВЧЕННЯ: КОНЦЕПТУАЛЬНІ ПІДХОДИ ДО ФОРМУВАННЯ}

Анотація: Розглянуто концептуальні підходи до формування та застосування окремих криміналістичних учень (теорій) як наукових конструкцій, щуо становлять основу структури загальної теорії криміналістики та визначають рівень розробки теоретико-методологічної бази ичієї науки. Складовою частиною загальної теорії криміналістики, ї̈ стрижнем виступають окремі криміналістичні вчення (теорії), які передують їй або, навпаки, породжуються нею і досліджують тільки певне коло закономірностей об 'єктивної дійсності з числа тих, які вивчає криміналістика в цілому. Запропоноване авторське визначення поняття «окреме криміналістичне вчення (теорія)» та висловлені пропозиції щзодо систематизації окремих криміналістичних учень, визначення їх місия у структурі загальної теорії криміналістики. Підкреслено, щзо характер закономірностей, які досліджує кожне з окремих криміналістичних учень (теорій), обумовлюють порядок їх упорядкування в структурі загальної теорії криміналістики. Водночас, між предметами загальної теорії криміналістики та окремих криміналістичних учень, існують відносини підпорядкованості изілого і частини. У структурі загальної теорії криміналістики дочільно виділяти два рівні окремих учень: 1) криміналістичні вчення (теорії) загальнонаукового рівня, щзо охоплюють наукознавчі проблеми; 2) криміналістичні вчення (теоріі) окремонаукового рівня, які стосуються дослідження закономірностей, що входять до предмета криміналістики, розкривають його сутність $i$ специфіку. Зазначено, шео сучасна система окремих криміналістичних учень (теорій) є динамічною і ї̈ вдосконалення зумовлене потребами судової та слідчої практики, розвитком суміжних галузей знань, загальної теорії і окремих криміналістичних учень, зміною зв'язків і залежностей між ними. Визначені критерії, яким має відповідати окреме криміналістичне вчення (теорія). Виокремлені дискусійні питання щүодо цієї проблеми, окреслено иляхи оптимізації наукових розробок у ц̧і й изарині знань.

Ключові слова: криміналістична діагностика, теорія криміналістики, механізм слідоутворення, механізм злочину.

Tanel Kerikmäe

School of Law

Tallinn Technical University

Tallinn, Estonia 
Volodymyr A. Zhuravel

National Academy of Legal Sciences of Ukraine Kharkiv, Ukraine

\section{PRIVATE CRIMINALISTICS DOCTRINES: CONCEPTUAL APPROACHES TO THE FORMATION}

Abstract: The conceptual approaches to the formation and implementation of private criminalistics doctrines (theories) have been considered as scientific constructions that form the basis of the structure of the general theory of criminology and determine the level of development of the theoretical and methodological basis of this science. The author's definition of the notion "private criminalistics doctrine (theory)» has been proposed, and suggestions are made to systematize private criminalistics doctrines and determine their place in the structure of the general theory of criminology. It has been emphasised that the nature of the regularities, explored by each of the particular criminalistics doctrines (theories), determines their order in the structure of the general theory of criminology. At the same time, there are relations of subordination of the whole and the part between the subjects of the general theory of criminology and private criminalistics studies. It is noted that the modern system of private criminalistics doctrines (theories) is dynamic and its improvement is conditioned by the needs of judicial and investigative practice, by the development of related branches of knowledge, the general theory and private criminalistics theories themselves, by changes in connections and dependencies between them. The criteria, that a private criminalistics doctrine (theory) must meet, are determined. The discussion questions in the problem under study are identified, the ways to optimise scientific research in this field of knowledge are outlined.

Key words: criminalistics diagnostics, criminalistics theory, inquiry mechanism, degeneracy mechanism.

\section{INTRODUCTION}

In the structure of the general theory of criminology as a system of ideological principles, theoretical concepts, categories and concepts, methods and relationships, definitions and terms [1], private criminalistics doctrines occupy the main place. On the whole, the general theory of criminalistics can be considered as a system of various degrees of generalisation and orientation of certain criminalistics teachings, which collectively form the theoretical and methodological basis of this science. Development of conceptual approaches to the formation and application of private criminalistics doctrines (theories), definition of their place in the structure of the general theory of criminalistics is one of the most topical areas of criminalistics researches, which determines the state of formation of its theoretical and methodological basis. That is why the development of established approaches to the systematization of private criminalistics doctrines, determining their place in the structure of the general theory of criminalistics should be considered and effective way to format modern scientific criminalistics paradigm. 
Such scientists as R. S. Belkin, A. M. Vasiliev, A. I. Wienberg, A. Yu. Golovin, V. G. Goncharenko, A. O. Eysman, A. O. Exparhopoulos, G. A. Zorin, S. Z. I. Kirsanov, V. V. Klochkov, V. O. Konovalova, V. Ye. Kornoukhov, I. M. Luzgin, G. A. Matusovsky, S. P. Mitrichov, V. O. Obraztsov, MV Saltevsky, M. O. Selivanov, V. G. Tanezevich, B. M. Shaver, V. Yu. Shepitko, M. P. Yablokov and others made the significant contribution to the development of private criminalistics doctrines. At the same time, in the modern domestic literature, there are almost no publications devoted to the study of conceptual approaches to the formation and realisation of private criminalistics doctrines (theories), the formulation of criteria and conditions under which a private theoretical constructions transform into private criminalistics doctrines. That is why the purpose of the article is to provide the author's definition of the notion "private criminalistics doctrine (theory)", to highlight the approaches to the formation and realisation of these scientific constructions, to determine the place in the structure of the general theory of criminalistics depending on the degree of development and generalisation of the elements of the object of cognition displayed by them, scientific and practical significance.

\section{MATERIAL AND METHODS}

The described scientific problem relates to the researches aimed at formation of the general theory of criminalistics that reflects the current level of development of this area of legal knowledge and belongs to the most important areas of criminalistics doctrine.

In order to achieve described goal, the author used the complex of general scientific and special methods of scientific knowledge. Thus, the use of dialectic and historical method of knowledge has allowed researching the evolution of scientific approaches to the formation of the general theory of criminalistics and its structural elements. The comparative method has created a possibility to demonstrate the difference between the general theory of criminology and private criminalistics theories, to determine approaches to its creation and realisation, to prove that the ratio of the subordination of the whole and the part existing between the subject of the general theory of criminalistics and private criminalistics doctrines is the criteria, which let relate certain theoretical structure to the theory of a certain level.

The use of Aristotelian method and system-structural approach allowed to classify private criminalistics doctrines depends on various degrees of development and generalisation of the elements of the object of cognition displayed by them, scientific and practical significance and to propose in the structure of the general theory to highlight criminalistics doctrines of general scientific and separately scientific level. The analysis method has provided the generalisation of accumulated theoretical knowledge regarding the understanding of the general theory of criminology and private criminalistics doctrine, approaches to their formation and realisation. 


\section{RESULTS AND DISCUSSION}

\subsection{The formation of the general theory of criminalistics and its structure}

Basing on the ideas of science studies regarding the fact that any theory must meet requirements of validity (to make assumptions, based on limited information, regarding fundamentally new facts or about the future state of studied objects), certainty (to describe results of research using terms of this theory), reasonableness (to set rational relations between certain ideas of theory), consistency (inside and with findings) [2]., R. S. Belkin highlighted such features of the general theory of criminalistics:

- Theory can claim to be general only if it covers the whole subject of research, related to it in its entirety, and not only to one of its elements;

- Conception or system of conceptions that are the content of the general theory should be related not to phenomena, but mostly to the essence of a subject of research and to explain this essence;

- Disclosing the essence of the subject of research, the general theory should reveal factors, which make this essence constant;

- Patterns of relations or connections of phenomena, i.e. patterns of the process, research of which is the purpose of this area of scientific knowledge.

- The general theory must be based on the principles of the theory of reflection that matters the scientific outlook and reflect the "dialectic of things" as the basis of the "dialectic of the idea", and not on the contrary;

- The general theory must be a closed conceptual system, elements of which are closely linked and organically interwoven with each other [1].

Despite a rather unequivocal understanding of the essence of the general theory, scholars have different views regarding the definition of its structure and elemental composition. Moreover, the complication of the problem necessitates researching it repeatedly, reconsideration of own views. Thus, R. S. Belkin firstly highlighted the following basic elements of the general theory of criminalistics:

1) Introduction to the general theory of criminalistics (scientific part of the general theory - the subject of science, its task, principles, laws of development and place in the system of scientific knowledge);

2) Private criminalistics doctrines (theories): the doctrine about the mechanism of crime, theory of criminal identification; theory of criminal diagnostics, criminalistics doctrine about indicators, doctrine about patterns of information about crime and its participants, about patterns of work with evidence, about crime, commitment and concealment of crime, etc. In the author's opinion, along with the developed criminalistics doctrines less developed and barely described should be highlighted as well;

3) Doctrines about criminalistics methods - methodology of criminalistics in the narrow sense of this notion;

4) Doctrines about language of criminalistics - system of notions and definitions that are used in criminalistics; 
5) Systematics of criminalistics - the principles of dividing of criminalistics knowledge into branches of science, from the system of criminalistics science in general, system of its branches and until private criminalistics systems and classifications [3].

Analyzing the suggested structure of the general theory of criminalistics, it is difficult not to notice that there is certain combination of different stages of generalisation of theoretical constructions; in particular, the doctrine of methods, the language, criminalistics systematics should relate to the theories of general scientific orientation, while the doctrine of the mechanism of crime, about patterns of information about crime and its participants, about patterns of work with evidence - to private scientific theories. The conception suggested by Belkin did not fully meet the criteria for this distinction of the general and private theories as whole and part, on which the author apparently also drew attention, because in following works he made the appropriate corrections. In the recent work of the "Course of Criminalistics" R. S. Belkin suggests a wider structure of the general theory of criminalistics, to the elements of which he includes:

1) The ideas, in which the idea of the subject of criminalistics is formed, its task, purpose and place in the system of scientific knowledge, the concept and content of its general theory (the first section - the introduction to the general theory of criminology).

2) The ideas that reflect the objective patterns of the crime mechanism in the aspect of criminology.

3) The ideas that reflect the objective patterns of information about a crime and criminal, patterns of gathering, evaluation and use of evidence, and that are the basis for the development of criminalistics means, methods and recommendations on the use of evidence in the practice of crime control, which are divided into four sections:

a) Criminalistics doctrine about patterns of information about a crime and criminal;

b) Criminalistics doctrine about patterns of gathering evidence;

c) Criminalistics doctrine about evaluation and use of evidence.

The system of private criminalistics doctrines about skills, commitment and concealment of crime; about the mechanism of marking formation; signs; fixation of evidence; about criminalistics registration; search; versions and investigation planning; general principles of the methodology of criminalistics expert research; causality; identification; forecasting, etc. The composition of the structure concludes with the doctrines of methods and language and criminalistics systematics, which make up three separate sections [1].

This architectonics of the general theory of criminology, of course, was a certain step forward and differed from the proposed designs in both form and content. However, it also has flaws. Firstly, trying to avoid previous mistakes, R. S. Belkin deduces from the system of private criminalistics theories the doctrine of the mechanism of the crime, although he calls it "the ideas that reflect the objective laws in the mechanism of crime in the aspect of criminology," that is hardly to consider more accurate. Besides from the gnosiological and epistemological perspective, it is not really correct to men- 
tion "doctrines of patterns" because doctrine (theory) is system of knowledge about certain groups of patterns of objective reality. In this regard, it is more expedient to speak of "criminalistics theory of crime", " criminalistics theory of crime knowledge", the subject of investigation of which will be the patterns of information of crime and offender, as well as patterns of gathering, study, evaluation and use of evidence. The results of the knowledge of the listed patterns are the basis of the formation and improvement of other private doctrines of a certain orientation, for example, doctrines of the version and planning, fixation of evidence, investigating situations, etc., and for the development of forensic means, techniques and recommendations in order to optimise the process of detection and investigation of a particular crime. Secondly, it is not completely understandable what three independent sections regarding doctrines of methods, language and criminalistics systematics were mentioned and where these sections' place in the system of criminalistics.

Ideas of M. V. Saltevskiy regarding this issues are close to the position of Belkin. Saltevskiy relates to the most important in the criminalistics doctrines the following:

1. Doctrine about patterns: a) mechanism of a crime commitment; b) occurrence of information, its sources about a crime and its participants; c) gathering and use of criminalistics information in proof.

2. Private criminalistics doctrines (theories) about: skills; features and characteristics; way of committing a crime; versions and planning (versioning); trace formation mechanism; systematization and registration of criminalistics sources of information; gathering, storage, processing and automated use of information; identification and grouping.

The list of private criminalistics doctrines (theories), as author emphasises, is changing with the development of science of criminalistics, depending on the needs of the practice of crime control, therefore the list is approximate [4].

Z. I. Kirsanov suggested the peculiar structure of the general theory of criminology, in which certain criminalistics theories are differentiated into two levels: those, which are elements of the general theory and those, which are studied in the different branches of criminalistics. He related to the first the doctrine about the mechanism of crime and its reflection; the doctrine about organisation of activity regarding detection, prevention and revealing of crimes and the doctrine of general methods of criminology [5]. A. V. Ischenko divides theories into fundamental (general) and applied. If theoretical structures affect the development of the whole science, are being used in all its components, then they are considered as applied. Fundamental theories are the general theory of criminology; the doctrine of the development of forensic science; the doctrine of the principles of criminology; the doctrine about methods; the doctrine of the subject; the doctrine of language; criminalistics theory of causality; criminalistics theory about the mechanism of trace formation; criminalistics theory of the sign; criminalistics theory of organisation of work with proofs; the theory of criminalistics cybernetics and 
others [6]. O. Yu. Golovin came to the conclusion that the most acceptable structure of the general theory of criminology is as science-based foundations of criminalistics; methodological foundations of criminalistics; system of separate criminalistics theories (doctrines) [7]. O. O. Eksarhopulo in the structure of the general theory of criminalistics highlights three sections: theoretical foundations of criminalistics science, criminalistics theories of crime, criminalistics theory of knowledge of the event of a crime in the process of its revealing, investigation and prevention [8; 9]. V. S. Mitrichev suggested in the theory of criminalistics such groups of doctrines: general doctrines, general teachings, that is, those which are the theoretical foundations of science in whole or of its separate sections, and individual doctrines, which are the scientific basis of existing areas of criminalistics activity [10]. V. O. Obraztsov also excludes from the general theory private criminalistics theories, distinguishing in the criminalistics system two components: the general part — the general theory and a special part — a collection of private doctrines and theories $[11 ; 12]$.

The listed ideas, but certainly, not all among those, which described in criminalistics literature concerning the system of criminalistics in general and its general theory in particular, suggest that this problem remains one of the most controversial science studies problems. In this connection it seems expedient to highlight certain thoughts, which must be taken into account in the realisation of the systematization of forensic knowledge. Firstly, differentiation of theoretical structures into general and private conditioned, primarily, by the degree of generalisation of the elements of the object of cognition displayed by them, wherein the degree is either criminalistics science or event of crime or activity concerning crime investigation. Secondly, theory can claim to be general only if it covers the whole subject of research, related to it in its entirety, and not only to one of its elements. Thirdly, the general theory itself as a section of criminalistics science is the systematic formation, which includes both theories of the theory of general scientific level, as well as private scientific theories. Analyses of nature and features of existing intertheoretical connection let to make the conclusion that the horizontal interconnection manifests itself mostly between the theories of general scientific level, and the vertical interconnection is more specific to the system of private scientific theories (doctrines): the theory of criminalistics identification - the theory of trasal identification - the theory of fingerprint identification. At the same time, the ratio of the subordination of the whole and the part existing between the subject of the general theory of criminalistics and private criminalistics doctrines is the criteria, which let relate certain theoretical structure to the theory of a certain level.

\subsection{The formation of private criminalistics doctrines (theories)}

The theoretical basis of criminalistics is continuously modifying, by theories of varying degrees of maturity, of scientific and practical significance are being added. For today it can be stated that criminalistics the same as any other science is the 
system of theories, because "only being the system of theories, science is able to explain different phenomena and correlations at present and to predict the course of development in the future" [13]. In particular, development of criminalistics doctrine of the victim [14], criminalistics classification of crimes [15], criminalistics theory of temporary connections and relations in the investigation of crimes [16], criminalistics theory of investigative situations [17], criminalistics characterisation of crimes [18], etc. can be considered complete. Serious steps have been taken to create a theory of criminalistics object [19], criminalistics theory of causality [20], forecasting $[21 ; 22]$ and so on.

At the same time, applications and statements about already formed or other new theory or necessity of creation of one have to be maximally reasoned given that not all theoretical constructions can claim to be private scientific theories. In such way, Obraztsov suggests to create " "general" (italics by us - V. Z.) criminalistics theory of interaction, scientific and practical need of which has been felt more clear" [23]. It seems that such situation is partly connected with the rather free interpretation.

This situation is partly due to the rather free interpretation of the largely controversial thesis of R. S. Belkin that "the system reserve (meaning individual theories - V. Z.) is consisted from private theoretical constructions or sets of such constructions, the consolidation degree of which may be evaluated differently by different researchers. The recognition or denial of such set by private criminalistics depends on such evaluation"[24].

The mentioned approach does not contribute to problems solutions, but, on the contrary, generates unnecessary discussions. All innovations claimed to be "private criminalistics doctrine (theory)" should meet the criteria, which has been developed or being developed in the criminalistics. Neglecting these criteria leads to a purely subjective, sometimes without sufficient scientific argumentation, evaluation of the results of a scientific research, to an artificial mechanical transfer into the general theory of such theoretical constructions, which were granted the status of private criminalistics theory by will of one or another scientist. "The theory of criminalistics programming expert and creative systems" [25], "the theory of complicated direct knowledge", "the theory of recognition" [26], "criminalistics ordology" [27] and others can fall into the category of doubtful theoretical constructions.

The process of determining the criteria, according to which it is expedient to evaluate one or another theoretical construction basing on whether there are indicators of doctrine (theory), have just started. Thus, R. S. Belkin highlights among such criteria, primarily, the general principles of formation and the reasonableness of conclusions [24]. Besides, each private criminalistics doctrine (theory) must have object, subject and methods of research, disclose the content and nature of relationships with other doctrines (theories), determine a purpose, a task, functions and a place in the system of criminalistics, be based on certain scientific hypotheses, have needed empirical foundation, and a corresponding degree of consolidation, which makes it pos- 
sible to identify certain patterns that complement, clarify the subject of science of criminology in general.

The oranisation of criminalistics (doctrines) included in the structure of the general theory of criminology should be made taking into account the following ideas:

- there are relations of subordination of the whole and the part between the subjects of the general theory of criminology and certain forensic students (theories);

- every private criminalistics doctrine (theory) supplements and specifies the subjects of criminalistics science, researching only a limited circle of patterns among those, which criminalistics studies in general. Ye. I. Zuev pointed out that private criminalistics doctrines "clarify the general theory of criminology, complement it with new data" [28];

- nature of patterns, which are studied by each of created criminalistics doctrines (theories), conditions the order of their division.

Given the above, it is considered expedient to highlight two levels of private doctrines in the structure of the general theory of criminology: 1) criminalistics doctrines (theories) of the general scientific level covering science-related problems of the object, subject, methods, sphere of research, system, nature, conceptual apparatus and the categories of criminalistics (the language of criminology), its inter-scientific connections and the place in the system of scientific knowledge, history of development and the present state; 2 ) criminalistics doctrines (theories) of a private scientific level relating to the study of the patterns that are part of the subject of criminology, reveal its essence and specifics.

Patterns are revealed and formed on the theoretical level basing on data of empirical research. The subject of criminalistics in a general sense is the system of interconnected patterns of two levels: 1) patterns of occurrence, existence and disappearance of information about the mechanism of a crime (functional side of criminal activity) and its consequences (traces); 2) patterns of receiving, researching, evaluation and use of information about the mechanism of crime and its consequences (traces) in the process of proof.

Basing on the ideas mentioned above criminalistics doctrines (theories) of private scientific level may be divided into following groups:

1. Criminalistics doctrines (theories) about mechanism of crime:

- Criminalistics doctrine about the mechanism of crime;

- Criminalistics doctrine about the mechanism of trace formation;

- Criminalistics doctrine about features;

- Criminalistics doctrine about skills;

- Criminalistics victimology;

- Criminalistics homology (doctrine about criminal identity);

- Criminalistics doctrine about time relations and connections;

- Criminalistics classification of crimes;

- Criminalistics characteristics of crimes, etc. 
2. Criminalistics doctrines (theories) of knowledge of the mechanism of crime

- Theory of criminalistics identification;

- Criminalistics theory of forecasting;

- Criminalistics doctrine about the version;

- Criminalistics theory of planning and organization of investigation;

- Criminalistics theory of fixation of evidence information;

- Criminalistics theory of causality;

- Criminalistics theory of tactical operations;

- Criminalistics doctrine about criminal registration, etc.

The given list of private criminalistics doctrines (theories) is not exhausted and final, because these doctrines are constantly developing, and changes of their system, according to N. I. Klimenko, are caused by such factors: a) occurrence of a certain need in the practice of crime control; b) the development of related branches of knowledge and their integration or differentiation; c) the development of the general theory of criminalistics as a result of penetration in the essence of the subject of science; d) the development of the private criminalistics doctrines (theories), changes of connections and relations between them [29].

\section{CONCLUSIONS}

The general theory of the criminalistics as the system of the main ideas of this area of knowledge, which covers maximally full reflection of the subject of science, its conceptions, categories, definitions, methods in a certain relations and intermediations, constantly develops. Fundamental ideas that are the foundation of the general theory are being updated and improved. The formation of the general theory reflects the current level of the development of the science of criminalistics.

The component and the core of the general theory of criminalistics is private criminalistics doctrines (theories) that precede it or, on the contrary, arise along with it and research only limited circle of the patterns of the objective reality among those, which criminalistics studies in whole. Every private criminological doctrine (theory) must have its own object, subject and methods of research, reveal the content and nature of relations with other theories (theories), determine the purpose, tasks, functions and place in the criminalistics system, be based on a certain scientific hypothesis, have the necessary empirical foundation, as well as the corresponding degree of consolidation, which makes it possible to identify certain patterns that supplement, clarify the subject of science of criminology in general. Only if they meet these requirements, private theoretical constructions can acquire the status of private criminalistics doctrine (theory).

In the structure of the general theory of criminalistics, it is expedient to highlight two private doctrines: 1) criminalistics doctrines (theories) of general scientific level covering science-related problems of the object, subject, methods, sphere of research, system, nature, conceptual apparatus and the categories of criminalistics (the language of criminology), its inter-scientific connections and the place in the system of scien- 
tific knowledge, history of development and the present state; 2) criminalistics doctrines (theories) of a private scientific level relating to the study of the patterns that are part of the subject of criminology, reveal its essence and specifics.

\section{REFERENCES}

[1] Belkin, R. C. (1997). Forensics course. In R. C. Belkin (Ed.) General Theory of Criminalistics. Moscow: Jurist.

[2] Gorskii, D. P. (1966). Scientific theory and methods of its generalization. Philosophy Issues, 8, $42-47$.

[3] Belkin, R. S. (1995). History, general and particular theories. In R. S. Belkin, V. G. Kolomackij, I. M. Luzgin (Eds.), Forensics (pp. 18-34). Moscow: Academy of Management of the Ministry of Internal Affairs of the Russian Federation.

[4] Saltevskij, M. V. (1997). Forensics. In the modern presentation of lawyers. Kharkov: Rubikon.

[5] Kirsanov, Z. I. (1992). The system of general theory of criminology. Moscow: Akademia MVD RF.

[6] Ishchenko, A. V. (1996). Methodological and organizational problems of the development of Crimean scientific research (Doctoral thesis, Ukrainian Academy of Internal Affairs, Kyiv, Ukraine).

[7] Golovin, A. Ju. (2002). Criminalistic systematics. Moscow: LeksJest.

[8] Jeksarhopulo, A. A. (1993). Forensic theory: the formation and development prospects in the context of the STR (Doctoral thesis, St. Petersburg State University, St. Petersburg, Russian Federation).

[9] Sedovaja, T. A., \& Jeksarhopulo, A. A. (1995). Kriminalistika. Forensics. St. Petersburg: Izd-vo LGU.

[10] Mitrichev, V. S. (1976). The theory of Soviet forensic science (debatable formulation of the question of so-called forensic studies). In V. S. Mitrichev (Ed.), Summary of the Scientific Message on the X Forensic Readings (pp. 25-29). Moscow: VNIISJe.

[11] Obrazcov, V. A. (1994). Forensics. Moscow: Jurikon.

[12] Obrazcov, V. A. (1996). Forensics. Moscow: Pravo i Zakon.

[13] Shtoff, V. A. (1978). Problems of the methodology of scientific knowledge. Moscow: Nauka.

[14] Centrov, E. E. (1988). Forensic doctrine of the victim. Moscow: Yuridicheskaya literatura.

[15] Obrazcov, V. A. (1988). Forensic crime classification. Krasnoyarsk: Publishing House of Krasnoyarsk University.

[16] Meshkov, V. M. (1995). Forensic doctrine of temporal links and relationships in the investigation of crimes (Doctoral thesis, Academy of the Ministry of Internal Affairs of Russia, Moscow, Russian Federation).

[17] Drapkin, L. Ja. (1987). Basics of forensic theory of investigative situations (Doctoral thesis, USSR Academy of the Interior, Moscow, Russian Federation).

[18] Kolesnichenko, A. N. (1985). Forensic characterization of crimes. Kharkov: Yuridicheskaya Literatura.

[19] Klochkov, V. V. (1988). The object, subject and system of Soviet forensics. Objects and System of Forensics in the Modern Research, 5, 7-24.

[20] Belkin, R. C. Forensic tools, techniques and recommendations. In R. C. Belkin (Ed.) So- 
viet forensics course (pp. 99-105). Moscow: Academy of Management of the Ministry of Internal Affairs of the Russian Federation.

[21] Gorshenin, L. G. (1993). Fundamentals of the Theory of Forensic Forecasting. Moscow: Academy of the Ministry of Internal Affairs of the Russian Federation.

[22] Zhuravel, V. A. (1999). Problems of the theory and methodology of forensic forecasting. Kharkiv: Pravo.

[23] Obrazcov, V. A. (1988). The problem of the formation of the concept of the object of criminology. Subject and System of Criminology in the Light of Modern Research, 2, 32-38.

[24] Belkin, R. S. (1987). Forensic science: problems, trends, prospects. General and particular theories. Moskow: Yuridicheskaya Literatura.

[25] Zorin, G. A. (2000). Theoretical fundamentals of criminology. Minsk: Amalfeja.

[26] Kornouhov, V. E. (2000). Forensics. A common part. Moscow: Jurist.

[27] Basai, V. D. (2003). Fundamentals of forensic ecology (Doctoral thesis, National Academy of Internal Affairs of Ukraine, Kyiv, Ukraine).

[28] Zuev, E. I. (1988). Subject, tasks, methods and system of the Soviet criminology. Forensics (Actual Problems), 3, 14-19.

[29] Klimenko, N. I. (2013). General and private forensic theory. Scientific Notes of the Tauride National University. V. N. Vernadsky. Series "Juridical Sciences", 26 (65), 1, 226-232.

\section{Tanel Kerikmäe}

$\mathrm{PhD}$, Professor

School of Law

Tallinn Technical University

19086, 5 Ehitajate Road, Estonia, Tallinn

\section{Volodymyr A. Zhuravel}

Doctor of Juridical Science, Professor

Full Member (Academician) of NALS of Ukraine

Chief Scientific Secretary

National Academy of Legal Sciences of Ukraine

61024, 70 Pushkinskaya Str., Kharkiv, Ukraine

Suggested Citation:Kerikmäe,T.,\& Zhuravel, V.A.(2019).Privatecriminalisticsdoctrines: conceptualapproaches to the formation.Journalof the NationalAcademyofLegal Sciences of Ukraine, 26(1), 98-109.

Submitted: 15/01/2019

Revised: 22/03/2019

Accepted: 28/03/2019 
УДК 340.5:342.3(53)

DOI: 10.31359/1993-0909-2019-26-1-110

Олена Володимирівна Зінченко

Кафедра міжнародного приватного права та порівняльного правознавства Наиіональний юридичний університет імені Ярослава Мудрого Харків, Україна

\title{
ОСОБЛИВОСТІ СТАТУСУ ПРЕЗИДЕНТА В АРАБСЬКИХ РЕСПУБЛІКАХ (ПОРІВНЯЛЬНИЙ АНАЛІЗ)
}

Анотація. Стаття присвячена дослідженню специфіки статусу президента в різних арабських республіках. Новизну даного дослідження складає виділення і групування визначальних особливостей статусу президентів в арабських республіках за їх різних типів. В роботі встановлена помітна тендениія поступових змін конституцій та республіканської форми правління арабських держав, які відбуваються під тиском глобалізаційного процеесу та подій «арабської весни». Конституиї̈ арабських республік передбачають чотири різновиди республіканського правління, в яких президенти мають різний статус та різний обсяг повноважень: суперпрезидентську республіку, президентську республіку, президентсько-парламентську республіку і парламентсько-президентську республіку. В арабських державах статус президента нерозривно взаємопов'язаний із формою правління. Автор доводить, щуо в арабських державах статус президента нерозривно взаємопов'язаний із формою правління. Суперпрезидентська форма республіканського правління фактично складає незалежну, неконтрольовану на практииі законодавчою або судовою гілками влади систему правління з гіпертрофованими президентськими повноваженнями. Президентська республіка характеризується персоніфікованістю інституту президента, у якій глава держави очолює виконавчу владу, а уряд несе відповідальність тільки перед президентом. Глава держави із президентською формою республіканського правління політично не звітує перед жодним органом. В президентсько-парламентських республіках основний обсяг повноважень у сфері виконавчої влади належить президенту, у парламентсько-президентських республіках обсяг повноважень президента значно менший, відповідні повноваження концентруються в руках прем'єр-міністра. У иій системі закладено механізм суттєвого пом'якшення властивих парламентській і президентській формам республіканського правління недоліків: для першої- нестабільності уряду, частих урядових криз й відставок, для другої-схильності до надмірної персоналізаиії державної влади, залежності від особи президента та ї̈ узурпаиіï.

Ключові слова: представник, арабські республіки, форма правління, референдум.

Olena V. Zinchenko

Department of International Private Law and Comparative Law Yaroslav Mudryi National Law University

Kharkiv, Ukraine

\section{FEATURES OF THE PRESIDENT STATUS IN THE ARAB REPUBLICS (COMPARATIVE ANALYSIS)}

\begin{abstract}
The article is devoted to the study of the specificity of the president status in a variety of Arab republics. There is a marked tendency for gradual changes in the constitutions and
\end{abstract}


republican forms of government form Arab states, which are under pressure of globalization process and work of "Arab spring". The author argues that, in Arab states status of a president indissoluble linked with the form of government. Super-presidential form of the republican governing body is virtually independent; in practice, the governing system of the legislative or judicial branches of power with hypertrophied presidential rights. The presidential republic is characterized by the personification of the president's institution, in which the head of state heads the executive power, and the government only bears responsibility before the president. The head of state with a presidential form of republican rule does not report politically to any institution. In presidential-parliamentary republics the main volume powers in the field of executive power belongs to the president, in the parliamentary-presidential republics the volume of powers of the president is much smaller, the respective powers are concentrated in the hands of the prime minister. In this system, the mechanism of renewal of its own parliamentary and presidential forms of disadvantages is laid down: for the first one - the instability of the order, the share of government crises and interest, for others - the situations preceding the personalization of state power, the personal president and his usurpation.

Keywords: representativ, Near East, form of governing, referendum.

\section{INTRODUCTION}

The head of state has always been of interest to researchers who paid attention to the people's ruler since the days of ancient Greece, when they considered the question of ethical obligations (Plato, Aristotle). In the Middle Ages, the question of the status of the ruler was raised up more often (M. Padua, N. Machiavelli, Ilarion, V. Monomah). For the first time the term "president" has appeared in the XVIII century at the same time as the introduction of the corresponding post in the USA. As for the research of the president institute, they appeared much later (M. Marchenko, M. Sakharov, G. Degtyev, I. Khutinayev, V. A Veryanov, V. Godovanets, V. Zhuravsky, V. Kravchenko, O. Lysenko, V. Malinovsky, M. Savchin, S. Seryogina, Yu Todig, V. Pogorilko, V. Shapoval and others ). Today, there is a lack of necessary attention of scholars to the problem of the president status in the Arab republics. Actually, this problem is very important given the fact that processes and events occur in the countries of the Middle East pose a potential threat to stability not only in the region but also in the whole world [1]. The domestic researchers studied the essence of the legal systems of the Arab countries (X. Behruz, P. Bowsunovsky, M. Burlatsky, V. Kolisnik, D. Lukyanov, I. Protsyuk, P. Rabinovich, Yu. Todika Yu Shemshuchenko and others). However, the features of the president status of the mentioned states were not the purpose of their researches and they did not conduct a comparative analysis.

Due to the intensity and contradiction of the functioning tendencies and peculiarities of the evolution of the Arab republics in the second half of the 20th century - the beginning of the 21 st century the problem remains relevant. The acuteness of the problems that caused "Arab Spring" and largely remained unresolved, necessitates the prevention of possible unwanted incidents and conflicts, and emphasizes the relevance of the meticulous research. 
The purpose of the article is to identify the features and status of the president in various forms of the republican system of the Arab States, to establish the characteristic features inherent to all four groups of states.

The novelty of this study is in selection and to grouping of the defining features of the status of presidents in the Arab republics by their different types. The material of the article is valuable to comparatists, researchers of the Arab states, teachers of the discipline "Comparative Law", students of the specialty "International Law" and especially masters who attend additional advanced courses of practical "Comparative Law".

\section{MATERIALS AND METHODS}

In an effort to explore the legal status of the presidents of the Arab republics, the author applied various theoretical methods. First of all, based on legislative and structural and integrate approach the above-mentioned states were analyzed, and that made it possible to define inherent in each fundamental characteristics, which determine the status of Arab presidents and their form of government. The main method was a comparative analysis of the subject of research, which is the core of achieving the purpose of the article. Its application has provided a determination of features of the president's powers in the Arab Republic four groups - super, presidential, presidential-parliamentary and parliamentary-presidential. Consideration of the president status of the Arab republics as one-line units contributed to the systematic method, according to which the problem of research was formulated. The principles of retrospective analysis, historicism and determinism ensured the establishment of causal relationships between Arab Spring processes in the investigated states and the adoption of new constitutions or substantial changes in the content of the "old" Basic Laws. The striving for objectivity in the presentation of the material is aimed to avoid the traditional in the Soviet studies assessments of bourgeois constitutions, parliamentary, distribution of branches of power, events and facts, but to ensure their impartial consideration.

The principle of analogy played an important role in solving the problem, the essence of which is to establish among the twelve Arab republics four the brightest models of the governance with a specific president status and the accession to each of them the corresponding among the last eight units. It is this principle that ensures the optimal length of the article by analyzing the twelve sources and the combination of the Arab republican states into four groups on the basis of identifying their fundamental features; in particular, that the Algerian People's Democratic Republic, the Republic of the Sudan, the Syrian Arab Republic, the Union of Comoros are the super presidential republics; the Arab Republic of Egypt, the Islamic Republic of Mauritania, the Republic of Djibouti, the Republic of Tunisia - the presidential republics; Republic of Yemen - the presidential-parliamentary and Lebanon, the Republic of Iraq and the Somali Democratic Republic - the parliamentary-presidential republic. 


\section{RESULTS AND DISCUSSION}

\subsection{Features of the status of presidents of Arab super presidential republics}

On November 19, 1976, the Constitution of the People's Democratic Republic of Algeria was adopted; on November 3, 1988, February 23, 1989, November 28, 1996 amended and supplemented, and on December 7, 1996 approved by the referendum. In accordance with its provisions, the President of the Republic may directly to carry out the will of the people (art. 6-7) [2]. The President of the Republic is the head of state, embodies the unity of the nation, he is the guarantor of the Constitution and the representative of the state inside and abroad and directly appeals to the nation. $\mathrm{He}$ is elected by universal suffrage, direct and secret vote and exercises the highest authority within the limits established by the Constitution (art. 70-72) [2]. To be elected President of the Republic, the candidate must: have only Algerian citizenship and origin; be a Muslim; be at least 40 years old on election day; enjoy all civil and political freedoms; provide certificate that the candidate's wife is a citizen of Algeria; confirm participation in the revolution of November 1, 1954 for candidates born before 1942; confirm the non-participation of parents of a candidate who was born after July 1942 in acts hostile to the revolution of November 1, 1954; provide a public declaration on their movable and immovable property in Algeria and beyond; other statutory conditions (art. 73) [2].

The term of the president's mandate is five years with only one reelection. He enters the post after the oath "before the people in the presence of all the higher authorities of the nation" (art. 74-76) [2]. The President is the supreme commander of the armed forces, the Minister of Defense, defines and conducts the foreign policy of the country, presides over the Council of Ministers, appoints and dismisses the head of government, issues presidential decrees, has the right to pardon, delay and mitigate the punishment, may appeal to the people for using a referendum on any issue of national importance, concludes and ratifies international treaties, confer awards and honorary symbols of the state. He appoints civilian and military positions provided for by the Constitution, members of the government, the head of the State Council, the Secretary General of the Government, the Governor of the Bank of Algeria, judges, heads of security agencies, etc (art. 77-78) [2].

The Head of Government presents his program for consideration to the National People's Assembly, in case of disapproval, he applies to the President of the Republic for his resignation. The president appoints a new head under the same procedures. Art. 87 of the Constitution states that the President of the Republic "in no case can delegate the authority to appoint the head of government and members of government, as well as heads and members of constitutional institutions, for whom no other form of appointment is provided for by the Constitution". At the same time, he cannot delegate the authority to "resort to a referendum, dissolve the National People's Assembly, make decisions on holding early parliamentary elections" and carry out the measures pro- 
vided for in art. 77, 78, 91, 93-95, 97, 124, 126, 127 and 128 of the Constitution [2]. In case of extreme necessity at the session of the High Council of Security, after consulting with the Head of the National People's Assembly and Head of the Council of the Nation, the President of the Republic declares an emergency or siege condition for a specified period and applies all necessary measures to normalize the situation. The term of emergency or siege status may be extended only with the approval of the parliament at the meeting of its two chambers. Organic law determines the situation associated with the emergency or the siege status. The state of emergency allows the President of the Republic to apply exceptional measures in the interests of preserving the independence of the country and protecting state institutions. At the meeting of the Council of Ministers, with the consent of the High Security Council, after consulting the head of the National People's Assembly and the head of the Council of the Nation, the President of the Republic proclaims the state of war in the case of actual or direct threatening aggression. During the period of the martial law, the Constitution is suspended, the President of the Republic exercises his powers. If the mandate of the President ends, he legally continues until the end of the war (art. 91-93, 95-96) [2].

One-third of the members of the Council of the Nation are appointed by the President of the Republic among the prominent figures of science, culture, professional, economic and social sphere. The number of members of the chambers should be the same $($ art. 98, 99, 101) [2]. On the initiative of the President of the Republic, the parliament may be convened for an extraordinary session, as well as on the initiative of the head of government or two thirds of the members of the National Assembly. Legislative initiative belongs to the head of government and deputies. The President of the Republic may send a message to Parliament. After consulting the head of the National Assembly, the head of the National Council and the head of government, the President of the Republic may decide to dissolve the National People's Assembly or appoint another parliamentary election. Members of the parliament have the right to ask the government for urgent issues, and parliamentary committees - to hear members of the government (art. 128, 129, 133) [2].

The Supreme Judicial Council is headed by the President of the Republic and makes a decision on the appointment, transfer and service of judges. The Supreme State Court examines acts that may be qualified as treason of the President of the Republic, as well as crimes committed by the head of government in the course of performing their functions (art. 153, 154, 155, 158) [2].

The Constitutional Council consists of nine members, three of whom are appointed by the President of the Republic, including the head, two elected by the National People's Assembly, two by the National Council, and one by the State Council. The Constitutional Council for the submission of the President of the Republic mandatory expresses his opinion on the compliance of organic laws to the Constitution after their adoption by the Parliament. The President of the Republic, the head of the National People's Assembly or the head of the National Council, convenes the Constitutional Council. If the Constitutional Council decides that any legislative or regulatory resolu- 
tion is contrary to the Constitution, they shall cease to have effect from the moment the decision of the Council is made. The reporting court, which is entrusted with the control of the finances of territorial teams and state institutions, makes an annual report to the President of the Republic (art. 165, 166, 169, 170) [2]. Under the President of the Republic, the Supreme Islamic Council acts, whose functions include promoting and encouraging the development of ijtihad, expressing opinions on the issues that are entrusted to it in terms of their compliance with religious requirements, and submitting to the President of the Republic a regular report on their activities. The Supreme Islamic Council consists of fifteen members. The President of the Republic appoints its head choosing among national figures with a high level of competence in various fields of science. Under the leadership of the President the High Security Council is being created, which is intended to express the President's opinion on national security issues. The forms of organization and activities of the High Council for Security are determined by the President of the Republic (art. 171-173) [2].

The decision to revise the Constitution is taken by the President, put to the vote at the National People's Assembly, and then on a referendum. The President of the Republic puts the decision of the latter into effect. The law on revision of the Constitution rejected by the people loses its force and cannot be re-passed to a referendum during the period of the parliamentary activity. In the event that, on the basis of the reasoned opinion of the Constitutional Council, the bill on the amendment of the Constitution does not in any way violate the basic principles of the Algerian society, the rights and freedoms of the individual and citizen, in no way affects the existing system of power and institutions, the President of the Republic may enter into force a law on change The Constitution without putting it on a national referendum, provided it is approved by three quarters of the members of the two chambers of parliament (art. 174-176) [2]. The President of the Republic enacts the amendments to the Constitution approved by the people (art. 182) [2].

Thus, the powers of President of the Algerian People's Democratic Republic, Head of State, Minister of Defense, Chief of the armed forces of the country have the right of direct appeal to the people through a referendum to resolve the issue of national importance, appointment and dismissal of the government and other senior officials of member the upper chamber, members of the High Security Council, members of the Constitutional Council, the Supreme Islamic Council, the conclusion and ratification of international treaties, the implementation of legislative functions via the decrees, the declaration of emergency or siege status, and the initiation of amendments to the Constitution have a wide list and a crucial nature, also give grounds for qualifying the form of government of Algeria as a super presidential republic (in the words of P. Bovsunovsky - over presidential) [3]. Similar determinations of the powers of the head of state (analogous status) contain the constitution of the Comoros, Syria and the Sudan, which also gives grounds to include their form of government in the number of super presidential republics $[4 ; 5 ; 6]$. 


\subsection{Features of the status of presidents of the Arab presidential republics}

Arab Republic of Egypt had the Constitutions of 1971 (changed and supplemented in 1980, 2005, 2007, 2011yy.), in 2012, and in 2014 yy. Basic Law was approved, according to which the executive branch headed by the President of the Republic, who is both head of state, independently issues orders that have the force of law (art. $139,156)$ [7]. A candidate for the post of President of the Republic must be a citizen of Egypt, born of Egyptian citizens, have no other nationality, use civil and political rights, have performed a military duty, be at the age of forty years. The President of the Republic is elected by direct universal suffrage for four years (art. 140-142) [7]. The President of the Republic appoints the Prime Minister, obliges him to form a government, with which he must determine the general policy of the state and control its implementation. He represents the state in external relations, concludes treaties and ratifies them after approval by the parliament. The President of the Republic is a supreme commander of the armed forces, appoints and removes civilian and military personnel, diplomatic representatives, after having consulted with the government, declares a state of emergency, gives amnesty and commutes sentences, convenes a referendum on important issues and interests of the state, results of which are mandatory on all state authorities and society. In case of committing a grave crime or treason, two-thirds of the members of the House of Representatives decide on the impeachment of the President (art. 143-157) [7].

Government members make an oath before the President of the Republic. The President of the Republic, the Prosecutor General and the House of Representatives, with the consent of a third of its members, may accuse the Prime Minister or the Minister of crime in the course of his tenure (art. 158-162) [7]. Public prosecution is an integral part of the judicial system. Attorney General appointed by the President of the Republic carried out it. The President of the Republic and Parliament should present bills on local elections to the Supreme Constitutional Court in order to determine their compliance with the Basic Law before their promulgation.

Consequently, the President of the Republic of Egypt is elected by universal suffrage, appoints the Prime Minister and other members of government and exercises executive power, the form of government is a presidential republic. Similarity of the provisions of the Basic Laws relating to the Head of State is characteristic of Djibouti, Mauritania and Tunisia, which illustrates that their form of government belongs to a group of presidential republics $[8 ; 9 ; 10]$.

\subsection{Features of the status of presidents in the Arab presidential-parliamentary republics ah}

Adopted in 1991, the Constitution of Yemen, as amended in 1994 and 1999, stipulates that the House of Representatives consisting of 301 deputies elected by universal suffrage for four years exercise the legislative power. Together with the members of parliament, members of the government also own the right of legislative 
initiative (art. 75, 768, 80-81, 84) [11]. After the formation of the new government, the Prime Minister presents the Government's Cabinet program to receive a vote of confidence. Government members are collectively and individually responsible for their activities to the parliament and may receive a vote of no confidence. The President of the Republic cannot dissolve the House of Representatives prematurely, except in the event of extraordinary circumstances, and only after a nationwide referendum on this issue (art. 85, 95, 97, 100) [11]. The executive power belongs to the President of the Republic and the Council of Ministers. The Head of the Republic is the President together with the Vice-President appointed by him. A candidate for the President may be any Yemeni, not younger than 40, born of Yemenis, with full political and civil rights, with a good character who carries out his Islamic duties and is not prosecuted, is not married to a foreign citizen. The President of the Republic is elected by universal suffrage on an alternative basis for five years with the right of only one reelection. The winner in the election takes an oath to the House of Representatives. He materializes the will of the people, protects national unity, the principles and goals of the revolution, is the supreme commander of the armed forces (art. 104-111) [11].

While in office, the President cannot conduct private business. He has the following powers: he represents the Republic on the international arena, sets the date of the parliamentary elections and referendum, appoints a person to form a government, issues a decree on the composition of the Cabinet of Ministers, implements the general policy of the state, appoints the members of the National Defense Council, signs the law, appoints and dismisses senior civil servants, officers of the armed forces and police, establishes military titles, makes awards, approves decrees of parliament's contracts and agreements, declares a state of emergency and general mobilization. While the House of Representatives on holidays, the President issues decrees with the force of law, which are subject to approval at the next parliamentary session. He has the right to request a report from the Council of Ministers on its activities. Without the President's approval, the death penalty cannot be enforced. The President forms the Advisory Board of qualified specialists. He may be accused of treason and actions that threaten the sovereignty of the country. The allegations should be made by half of the House of Representatives and supported by two-thirds of the votes (art. 117-119, 122-123, 125-126) [11].

The Council of Ministers is the Government of the Republic of Yemen and the highest executive and administrative power of the state. The prime minister and ministers must meet the same requirements as members of parliament, be at least 30 years of age, and the Prime Minister is not less than 40 years old. The Government is collectively responsible for its activities before the President of the Republic and the House of Representatives, and before joining its members take an oath to the President of the Republic. The powers of the government include participation with the President of the Republic in defining the common areas of domestic and foreign policy, drafting eco- 
nomic development and budget, drafting laws, approving agreements and covenants before submitting to parliament, and implementing measures to protect the security of the state. The President of the Republic and the House of Representatives may bring to justice members of the government for any crime (art. 127, 129-130, 137) [11].

Since government members are collectively and individually responsible before the House of Representatives and the President, the form of government of Yemen is defined as a presidential-parliamentary republic.

\subsection{The specifics of the status of presidents in the Arabian parliamentary-presidential republics}

The first Constitution of Iraq was adopted in 1970, which was amended by the Basic Laws of 2000 and 2005 of the Constitution of 2005, stipulates that the bodies of the Federal Legislature are the Council of Representatives and the Council of the Union. The Council of Representatives is elected by a direct universal suffrage and secret vote and is intended to represent all segments of the population. The term of office of the Council is four years. The President of the Republic convenes the Council for the session by his decree, which holds two sessions per year with a total duration of eight months (art. 52, 54, 55) [12]. Council of Representatives has the following powers: adopts federal laws; supervises activity of executive power; elects the President of the Republic; ratifies international treaties; approves the appointment of the head and members of the Federal Cassation Court, the Chief Prosecutor's Office and the head of the Department of Court Inspections; the ambassadors, the Chief of the General Staff of the Army, and his deputies, assigns the rank of generals and higher, the head of the intelligence service on the proposal of the Council of Ministers. The Chamber hears the President of the Republic, on the basis of a request approved by a majority, dismisses the President of the Republic by an absolute majority after his condemnation for violation of the oath, the Constitution or treason by a federal court. Members of the Council of Representatives have the right to make requests to the Prime Minister and ministers and to express their lack of confidence. They approve a declaration of war and the a state of emergency on the proposal of the President of the Republic and the Prime Minister (art. 58) [12]. The Council of Representatives may be dissolved by an absolute majority of votes on the basis of a requirement of one third of its members or on the proposal of the Prime Minister approved by the President of the Republic $[1 ; 2]$. The Council of the Union is a legislative body consisted of representatives of districts and provinces. Its election and conditions of activity are regulated by law (art. 62) [12].

The executive branch consists of the President of the Republic and the Council of Ministers. The President of the Republic is the head of state and a symbol of national unity. It embodies the sovereignty of the country, guarantees commitment to the Constitution, protection of the independence of Iraq, unity and security of its territory. The candidate for the President must be Iraqi at birth, meet the conditions of election and 
be not less than 40 years of age, have a good reputation, political experience, be honest, conscientious, equitable and devoted to his homeland, not to be accused of moral crimes (art. 63-65) [12]. The Council of Representatives elects the President of the Republic for this position by a two-thirds majority. The president takes the same oath, with which members of the Council of Representatives take office. The President occupies his post for four years and can be reelected only once (art. 67-69) [12].

The President of the Republic exercises the following powers: grants clemency on the recommendation of the Prime Minister, except for those accused of private litigation, international crimes, terrorism, financial or administrative corruption, and crimes against individual rights; signs international treaties and agreements after their approval by the Council of Representatives; signs laws approved by the Council; convenes newly elected Council of Representatives in session; awards orders on the recommendation of the prime minister; accredits ambassadors; issues presidential decrees; approves death sentences; carries out the supreme command of the Armed Forces. The Council of Representatives should elect a new President within 30 days of the date of the vacancy art. $(70,72)[12]$. The President of the Republic proposes a candidate for the post of Head of Government, proposes to form the Cabinet of Ministers and prepare a government program approved by a majority of the members of the Council of Representatives. A candidate for the Prime Minister must meet the same requirements as a candidate for the President of the Republic, and have a graduate degree. The same requirements are for candidates for ministerial positions. The whole structure of the government brings the same oath as the President. The Prime Minister, as a direct representative of the executive branch, is responsible for the general policy of the state, is the Supreme Commander of the Armed Forces, manages the work of the government and presides at its meetings, has the right to remove ministers from office with the consent of the Council of Representatives (art. 73-76) [12].

The Cabinet of Ministers plans and implements the general policy of the state and develops general state plans, issues rules, instructions and decisions on implementation of laws. He prepares a draft state budget, a final financial report and development plans, presents to the Council of Representatives for the approval candidates in deputy ministers, ambassadors and other special-ranking officials, the chief of the general staff of the army, his deputies, generals, the director of the intelligence service and the heads of security institutions, conducts international negotiations and signs them. The National Intelligence Service is subordinated to the Cabinet of Ministers. The Prime Minister and ministers are collectively and personally responsible for their activities before the Council of Representatives. The President of the Republic holds the post of Prime Minister in the event of its vacancy (art. 77, 78, 80, 81) [12].

The federal Supreme Court is financially and administratively independent judicial body. It covers judges and experts of Islamic law and secular legislation, controls the compliance with the laws of the Constitution, interprets its provisions, makes decisions on matters arising from federal laws, conclusions, rules, instructions and procedures 
adopted by the federal authorities. This court decides on allegations against the President of the Republic, the Prime Minister and the ministers, approves the final results of the general parliamentary elections, resolves disputes between the federal judiciary and the judicial authorities of regions and provinces that are not part of the region. The decisions of the Federal Supreme Court are final and mandatory for all authorities (art. 89-91) [12].

A. Sukharev and the authors called the form of government of Iraq a super presidential republic [13], which was fully in line with reality from the perspective of the Constitution of 1970. The Iraqi constitution of 2005 replaced the election of the President of the Republic by universal suffrage with the election of the parliament and transferred a significant part of his powers to the Prime Minister and the Council of Representatives, which gives grounds for qualifying the form of government of the country as a parliamentary-presidential republic. According to the constitutional characteristics of the powers of the Presidents of Lebanon and Somalia, who have the same status as the President of Iraq, their forms of government are also the parliamentarypresidential republics $[14 ; 15]$.

\section{CONCLUSIONS}

Consequently, the constitutions of the Arab republics provides four different types of republican rule in which the presidents have different status and different powers: the super presidential republic, the presidential republic, the presidential-parliamentary republic and the parliamentary-presidential republic. In the Arab states, the status of the president is inextricably linked with the form of government. The super presidential form of republican rule is actually an independent, uncontrollable in practice by the legislative or judicial branches of power form of government, the main point of which is hypertrophied presidential powers. In the vast majority of cases, the super presidential republic envisages a totalitarian or, in the extreme case, an authoritarian political regime. The Arab super presidential republics include the Algerian People's Democratic Republic, the Republic of the Sudan, the Syrian Arab Republic, and the Union of Comoros.

The presidential republic is characterized by the personification of the president's institution. In it, the president heads the executive powers, independently issue decrees having the force of law. The general sign of the relationship between the legislative and executive power in the presidential republic is the lack of responsibility of the government before the parliament, as it is only responsible to the president. The head of state with a presidential form of republican rule does not report politically to anybody. Even the procedure of impeachment is the removal of the president from the authorities not because of the ineffectiveness of his policy, but for the commission of a crime. The only mechanism of political responsibility of the executive power in this case is the election. The Presidential republics are the Arab Republic of Egypt, the Islamic Republic of Mauritania, the Republic of Djibouti and the Tunisian Republic. 
A mixed form of republican rule combines elements of the presidential and parliamentary republics. A mixed form of republican rule is characterized by a clearly expressed bicefal system of executive power. There is a peculiar combination of elements of parliamentary and presidential democracy. In this system, the mechanism of substantially mitigating the peculiar defects inherent to the parliamentary and presidential forms of the republican government is laid down: for the first one - instability of the government, frequent government crises and detentions, for the second - a tendency to excessive personalization of state power, depending on the person of the president and his usurpation. The mixed republics are the Presidential-parliamentary Republic of Yemen, as well as the Republic of Lebanon, the Republic of Iraq and the Somali Democratic Republic, which are parliamentary-presidential.

The forms of government, in which the absence or presence of legislative bodies do not play a decisive role because the head of state - the monarch or the president occupies a central place in the system of government of the Arab states, is due to longlasting historical traditions. The constitution establishes the prerogatives of the head of state, his decisive role in defining the state policy and in appointing and dismissing senior civilian and military officials responsible to him. The powers of the executive authorities are reduced to consultation and recommendations for the head of state. In the republics, the bill before being submitted to the parliament is subject to approval by the president; therefore, in fact, the president holds legislative powers. The upper chambers, as a counterweight to the lower chambers, are formed from politicians loyal to the head of state. Subordination of the opposition to the head of state is carried out by the dissolving parliaments, the definition of electoral districts, and the reservation of seats in the parliament by religious and ethnic minorities. All this reflects bounded under the content of the constitution the state government and the practice of constitutional regulation of social relations. The author notes that the length of the article did not allow at least to briefly highlight the role of Islam and Sharia, as well as the significance of historical traditions in determining or changing the forms of government of a state that affect the status of the president.

\section{REFERENCES}

[1] Orlova, T. V. (2013). Modern political history history. Kiev: Znannya.

[2] Constitutions of states (countries) of the world. (2010). The Constitution of the Algerian People's Democratic Republic (adopted on November 19, 1976, as amended by referendum on November 28, 1996). Retrieved from http://worldconstitutions.ru/? $\mathrm{p}=53$.

[3] Bovsunivskiy, P. V. (2012). Features of the formation of political systems and trends in the political development of the Arab world. Actual Problems of International Relations, 111(1), 77-84.

[4] Constitutions of states (countries) of the world. (2001). Constitution of the Comoros, adopted by referendum on December 23, 2001. Retrieved from http://worldconstitutions.ru/ $? \mathrm{p}=63$.

[5] Constitutions of states (countries) of the world. (2012). The Constitution of the Syrian Arab Republic of February 26, 2012. Retrieved from http://worldconstitutions.ru/?p=459. 
[6] WIPO. (2005). The interim national Constitution of the Republic of the Sudan. Retrieved from https://wipolex.wipo.int/ru/text/241714.

[7] Constitutions of states (countries) of the world. (2014). Constitution of the Arab Republic of Egypt. Adopted in a referendum on January, 14 and 15, 2014. Retrieved from http://worldconstitutions.ru/?p=1013.

[8] Constitutions of states (countries) of the world. (2010). Constitution of Djibouti, adopted September 4, 1992. Retrieved from http://worldconstitutions.ru/?p=58.

[9] Constitutions of states (countries) of the world. (2010). Constitution of the Islamic Republic of Mauritania, adopted July 12, 1991. Retrieved from http://worldconstitutions.ru/?p=65.

[10] Constitutions of states (countries) of the world. (2014). The Constitution of the Tunisian Republic. Adopted on January 26, 2014. Retrieved from http://worldconstitutions.ru/?p=1049.

[11] Constitutions of states (countries) of the world. (2010). Constitution of the Yemen Arab Republic with constitutional amendments of 1994 and 1999. Retrieved from http://worldconstitutions.ru/?p=81.

[12] Constitutions of states (countries) of the world. (2011). Constitution of the Republic of Iraq, October 15, 2005. Retrieved from http://worldconstitutions.ru/?p=338.

[13] Sukharev, I. (2003). Legal systems of countries of the world. Moscow: Publishing house NORMA.

[14] Constitutions of states (countries) of the world. (2010). Constitution of the Lebanese Republic on May 23, 1926, as amended: October 17, 1927, May 8, 1929, November 9, 1943, December 7, 1943, January 21, 1947, May 22, 1948, April 24, 1976, September 21, 1990. Retrieved from http://worldconstitutions.ru/?p=90.

[15] Constitutions of states (countries) of the world. (2013). Interim Constitution of the Federal Republic of Somalia. Adopted on August 1, 2012. Retrieved from http://worldconstitutions.ru/?p=777.

\section{Olena V. Zinchenko}

Doctor of Sciences (History), Associate Professor

Department of International Private Law and Comparative Law

Yaroslav Mudryi National Law University

61024, 77, Pushkinskaya Str., Kharkiv, Ukraine

Suggested Citation: Zinchenko, O. V. (2019). Features of the president status in the Arab Republics (comparative analysis). Journal of the National Academy of Legal Sciences of Ukraine, 26 (1), 110-122.

Submitted: $11 / 01 / 2019$

Revised: 11/02/2019

Accepted: 28/03/2019 
УДК 347.155

DOI: 10.31359/1993-0909-2019-26-1-123

\author{
Ханс Іоахім Шрамм \\ Iнститут Східного права \\ Університет технологій, бізнесу та дизайну \\ Вісмар, Німеччина
}

\author{
Анатолій Володимирович Коструба \\ Кафедра иуивільного права \\ Прикарпатський наиіональний університет імені Василя Стефаника \\ Івано-Франківськ, Україна
}

\title{
ПРАВОВА КЛАСИФІКАЦІЯ ВИДІВ ІНФОРМАЦІЇ ПРО ФІЗИЧНУ ОСОБУ
}

Анотація. Прочеси використання, поширення, зберігання інформації сприяють виникненню інформаційних правовідносин. Тому основна мета роботи полягає у аналізі правової класифікачії видів інформачії про фізичну особу. Встановлено, щуо сочіальна правова держава зобов'язана забезпечити інформаційні права громадян як на отримання доступу до інформації, так і стосовно нерозповсюдження певних видів даних для захисту прав їх власників. Автором було сформовано власний погляд на класифікацію персональних даних фізичної особи в ијивільному праві Украӥни. Виявлено, щуо правова природа персональних даних фізичної особи полягає в тому, щуо останні складає інформація - як сукупність відомостей про певні події, явища, стан тощо. Ця інформація індивідуалізує суб' 'ккта права - фізичну особу, який в свою чергу наповнює ї̈ певним змістом. Загальновідомим є той факт щзо фізична особа як суб' єкт циивільних правовідносин має суспільні і природні ознаки, які впливають на його правовий статус і певним чином індивідуалізують його. До біологічних персональних даних слід віднести відомості про морфофізіологічні, біохімічні і психологічні ознаки особи. Соціальні персональні дані складаються із відомостей про сімейний стан, рівень освіти тощо. Запропоновано встановити наступну класифікацію: номінативні персональні данні фізичної особи, якими є прізвище, ім'я, по батькові, дата народження тощчо як базисна умова їх класифікаиіï, а також варіативні персональні дані фізичної особи - освіта, сімейний стан, місие проживання тощо, за допомогою яких встановлюється змістовність інформації про особу, досягається можливість чіткішій ідентифікації індивідуума в «правовому полі». Їх мета первісно визначити суб 'єкта на підставі його загальної характеристики. Варіативні персональні дані можуть накопичуватися або змінюватися під впливом обставин дійсності, наприклад, за минулістю часу. Консолідуючись з номінативними, вони сприяють досягненню мети персоніфікації фізичної особи чим забезпечується обігоздатність інформації про фізичну особу.

Ключові слова: персональні дані, документована інформація, біометричні персональні дані, немайнові правовідносини. 
Hans Joachim Schramm

Institute of Eastern Law

University of Technology, Business and Design

Wismar, Germany

Anatoly V. Kostruba

Department of Civil Law

Vasyl Stefanyk $P_{\text {recarpathian National University }}$

Ivano-Frankivsk, Ukraine

\title{
LEGAL CLASSIFICATION OF TYPES OF INFORMATION ABOUT AN INDIVIDUAL
}

\begin{abstract}
The processes of use, distribution, storage of information contribute to the emergence of information relations. Therefore, the main purpose of the research is to analyze the legal classification of the types of information about an individual. It has been determined that the social legal state is obliged to ensure the information rights of citizens both to gain access to information and to non-proliferation of certain types of data in order to protect the rights of their owners. The author has formed his own view on the classification of personal data of an individual in the civil law of Ukraine. It is determined that the legal nature of the personal data of an individual is that this personal data is information as a collection of information about certain events, entities, status, etc. This information individualizes the subject of law - an individual who, in turn, fills it with certain content.
\end{abstract}

Keywords: personal data, documented information, biometric personal data, non-property relations.

\section{INTRODUCTION}

As individualized subject of civil law an individual is constantly in civil law relations with other subjects. Such legal connection is preceded by information about entities, events or legal status of things, with which parties intend to enter into civil legal relations. Certain roles in the formation of legal relations between subjects of law are also the content and flow of information about an individual, with the use of which it is possible to create one or another legal relation.

Despite the fact that the notion of the personal data is defined in Ukrainian legislation, its content and classification need to be clarified. Thus, article 2 of Ukrainian law "On personal data protection" states that personal data is data or collection of information about the physical person who is identified or can be specifically identified [1]. At the same time, this legal act does not disclose the content of such data. There are no details of data classification about an individual (personal data) in article of law of Ukraine "On information" [2]. It contains the open list of such information as data on nationality, education, marital status, religious beliefs, state of health, as well as address, date and place of birth, etc. 
Analysis of scientific researches concerning this topic also does not give a full answer to the question about classification and content of data about an individual (personal data). Thus, scientists such as V. Bridzhko, O. Kulinich, E. Petrov, A. Chernobay paid attention to the study of the issues of the protection of the right to privacy, the flow of personal data of an individual, but they were more focused on the organization of the processing of personal data in the sphere of public legal relations.

At the same time, the uncertainty regarding the classification of personal data of an individual may lead to a violation of the rights of the latter, in the case of dissemination of data that is not included in the list established by the current legislation of Ukraine, but significantly affect the identity of its owner. This is due to the fact that the individual independently determines the degree of influence of the dissemination of information about him and his spiritual state. This determines the relevance of the study of this issue in the context of its private legal regulation.

The purpose of the article is to disclose types of information about an individual (personal data) and create their legal classification on the basis of the established criteria.

Therefore, information about an individual (personal data) is specific information about subjective civil rights and legal obligations of a person, or his/her legal status, which ensure the legal personification of an individual.

\section{MATERIAL AND METHODS}

The processes of democratization of the power relations system and the state mechanism of Ukraine at the present stage provide the legal regulation of information openness of state authorities and local self-government bodies. For a more detailed study of the question, the author used a variety of theoretical methods. The analysis of modern foreign legislation in the field of information relations allows distinguishing the following characteristic features that provide public access to public information:

- acts that regulate public access to public information are constitutional;

- all public information with a few exceptions is accessible for media, scientific organizations, parties, citizens;

- the list of information, which is secret, is determined by law;

- departmental specification of secret data is allowed in exceptional cases, subject to approval by parliament;

- both citizens of the state and foreigners have access to public information;

- officials are obliged to provide information about their activities.

The method of analysis also allowed to find that the growing demand for information leads to the dividing information activities into a separate form that results in appearing of intangible objects of legal relations. The mentioned actualizes the problem of scientific research concerning the protection and defense of information resources in databases, in particular in the aspect of ownership of information. Therefore, scientific research includes certain sequence of actions, methods, operations, which contribute to learning of objective reality. 
Through the methodological basis there were determined basic notions that explain scientific events and disclose patterns. The methodological basis of scientific research means the basic, initial provisions on which it is based. There were determined patterns and mechanisms of legal classifications of types of information about an individual.

\section{RESULTS AND DISCUSSION}

\subsection{Features of classification of property and non-property relations}

With a view to hermeneutic clarity, the author equates the notions of information about an individual, record about an individual and the notion of personal data of an individual, because their legal sense is an individual identification. In order to disclose the content of this data, criteria of their legal classification, we turn to legal nature of information about an individual (personal data).

All existing in civil society relations are conventionally divided into two groups. When implementing the first of them, the subjects interact with each other in order to change the state of physical substance which forms the object of such relations. They are property (alienation of property or its creation, temporal transfer of this property to another person, etc.).

The essence of the second group is interaction of subjects without material component of these relations. R. O. Halfina paid attention that there are such relations in law [3]. Their sense is spiritual life of human, a purpose of which is satisfaction of physiological, cultural, social needs, etc. The multifaceted nature and diversity of personal non-property legal relations is explained by the theoretical doctrine of natural law and disclosed by the theory of plurality of personal rights, which is currently supported by the majority of scholars [4]. Its general meaning is that the diversity of personal nonproperty interests influences the diversity of civil-law forms of mediation.

This is absolutely reasonable because the evolution of humankind conduces changes, improvements or cessation of human everyday needs. They are in constant dynamics. Their amount cannot be clearly regulated by the current legislation of Ukraine. The state establishes an "open" list of general human rights and freedoms, which is not limited to the norms of the constitutional law of Ukraine. He has a certain level of abstraction. Consequently, the amount of personal non-property relations is not exhausted. Their type classification has no sense. Only generic classification of personal non-property rights is expedient. Its purpose is to determine inside-system patterns of development of non-property rights, mastering the theoretical and legislative material in their legal regulation.

Mane scientists paid attention to the matter of classification of personal non-property relations $[5 ; 6 ; 7]$. The author consider expedient to adopt the classification provided by N. O. Davydova. It is based on the activities of the subject of law, aimed at achieving the goal, which is the basis of the instrumental approach in jurisprudence that 
receives a significant spread in law of the present. The initiative in applying certain decisions is a feature that allows taking into account the instrumental approach, based on the assessment of human choice of the implementation of the solution in its own activities, within which this feature is able to work [4].

In such way, N. O. Davydova divides personal non-property relations into two groups: 1. Rights that provide the natural existence of an individual (right that provides well-being; right to liberty and security of person; right to marriage, family, care, etc.). 2. Rights that provide the social existence of an individual (the right to individualization of citizens in society, the rights that provide the autonomy of the individual (the privacy of personal life), the rights that protect the results of intellectual activity, the rights that contribute to the multilateral development of the individual and the expression of his creative personality, etc.) [4].

An amount of personal non-property rights is the competence of an individual - a subject of civil law to a certain legal behaviour in relation to the goods of immaterial nature, which are the object of law. The consent of such goods is information about status of things, entities or events that occur in a society and to which the subject has a direct legal interest. For example, the rights of personal life that provide privacy include a competence of the relevant subject to certain actions to protect them. In particular, these are the right to have the information about private life of the human, the savings, the protection or the promulgation. In such way, this information is indicated as the connection of the object with the category of interest and the needs of the subject.

At the same time, objects mean philosophical category that define any real or imaginary reality, which is considered as something external in relation to a person and becomes the subject of person's theoretical and practical activities. If to consider this phenomenon as a matter of law, the object is the search legal effect, the subject of legal control, which is achieved by the content of the law (or the content of legal relations) [8].

The presence of social or economic value strengthens the point of view that information about certain phenomena, state or events is considered as an object of law. This information reflects professional competence, ability to work and other social properties of a person. They characterise the individuality of each person as a carrier of unique elements of physical, physiological, psychological, economic, cultural or social identity that has a certain legal value.

From the social and philosophical perspective, this information is a reflection of the reality, which can be stored on physical media or displayed electronically. In such way, it is certain information about the subject of law, which reflects his or her individuality, social activity, and is the subject of civil law, receives legal protection against a possible violation by an uncertain circle of persons. Using information about an individual (personal data) person's competence, which provides the implementation of personal non-property rights, is formed. 


\subsection{The features of personal data}

Closely related to the identity of the possessor of a right, such information is a segment of the right to privacy guaranteed by art. 32 of the Constitution of Ukraine, that is, personal data is also the object of personal non-property legal relations. It should also be emphasised in the light of the foregoing the feature of personal data is its abstractness. The list of types of information about an individual (personal data) cannot be exhausted and has conditional nature.

There are many criteria to classify information as object of law. Some scientists insist that classification of information cannot be divided. On the contrary, it has to be single, integral and based on an integrated, systematic approach. Complexity, systematic classification involves the singling out and consideration of all possible types and types of information in civil law [9].

Typically, the classification depends on the purpose, which requires for achieving a more in-depth study of the subject through its classification.

According to V. G. Afanasiev as an object of law information can be divided into types on the following basis: 1) on the basis of its relation with the time in which it is created and used. Accordingly, information about the past, present and future is highlighted; 2) by the source of information social and political (including economic, family-household, etc.), scientific and technical, accounting and statistical information varies; 3 ) by the focus: horizontal information, the flows of which circulate between the authorities of one level, and vertical, circulating through vertical channels; 4) by the form of the material carrier: visual (visible, documentary) and sound (audible), teleinformation, newspaper, magazine, embodied in artistic works, etc .; 5) by the possibility of its repeated use: fixed (documented) - materialized on paper, electronic memory, etc. (can be used repeatedly) and unpublished (undocumented) - used once, at the moment of receipt [10].

V. N. Lopatin also suggests certain grounds to classify the information: 1) by the degree of organisation (ordering) - documents and other information; information resources and free information, which is not listed in information resources; systemized (catalogs, encyclopedias, rubrications, etc.) and not systemized information; 2) by the type of carrier (form of fixing) - on a paper carrier, video and sound, computer information, in volume and spatial form, oral, energy (biological) during energy information exchange; 3 ) by the function (by the scope of application) - mass information distributed through the media, industry, professional information of interest; 4) by degree of access - restricted information, information without restriction of access, intellectual property objects, "harmful information" with restrictions on distribution, other public information [11].

V. A. Kopylov classifies information basing on features of the legal regulation in information relations: 1) information as a result of art; (achievements, inventions, discoveries); 2) mass information containing informative messages; 3 ) documented information about citizens (personal data); 4) official documented information; 5) informa- 
tion, obligatory provided by legal entities and individuals in the order of reporting on their own activities; 6) information that is not the result of art, but is formed and distributed as a product; 7) information in the form of information resources as arrays (stocks) of retrospective information [12].

Undoubtedly, each of the mentioned classifications has its own scientific sense, because it allows disclosing a sense of certain information in different contexts, determining features of the legal regulation of this information. However, the given classification is of general theoretical nature. Unfortunately, it does not reveal functional meaning of such legal phenomena as personal data of an individual. It is about the role of this phenomenon in the micro mechanism of regulation of legal relations, in which personal data is their object. This allows determining features of legal regulation of personal data flow in civil legal relations, revealing their meaning.

In such way, classification made by N. I. Petrikina is very interesting. Depending on a legal regime of flow and a scope of application of personal data, she determines three types: publicly available personal data; special categories of personal data; biometric personal data. The first refers to the personal data, access to which provided by the person concerned. This information can be reported by an individual and the content of which is his daily social interaction. Special categories of personal data include information about race, national identity of a person, political views, religious beliefs, state of health, etc. Biometric personal data is information that characterises the physiological features of a person, on the basis of which it is possible to identify a person (blood group, DNA code, fingerprints, etc.) [13].

It should be emphasized that some researched suggest other variants of differentiation of only personal data. In particular, V. Y. Ishenkov divides it into following categories: physical, physiological, and relative personal data. Physical and physiological are a genus, DNA composition, digital external image, height, body weight, blood composition, etc. In relative author includes: place and date of birth, ethnic origin, social status, family status, number of children, place of birth, salary level, address and contact information, political views, etc. [14].

In general without denying the positions of mentioned scientists, we consider expedient to create the own view on classification of personal data of an individual in civil law of Ukraine. It is well-known fact that an individual as subject of civil legal relations has social and natural features that influence his or her legal status and in a certain way individualise him or her $[15 ; 16 ; 17]$. This is due to the dual nature of human as a biological and social being. Therefore, it is expedient to divide personal data of a person into biological and social (socio-political, legal). Biological should include information about morpho-physiological, biochemical and psychological characteristics of the person, namely: information about the state of health, sex, year of birth, physiological image, etc. Social personal data consists of information about the marital status, level of education, children, professional employment, citizenship, religion, 
political affiliation, public position, credit history of a person, conviction, legal obligations, etc.

This is a doctrinal classification of personal data, which allows determining their list in the static of legal relations. However, this is not enough, since the static does not reveal the functional meaning of a particular type of personal data of an individual for the purpose of its identification. Thus, based on the analysis of information about an individual in a group of biological or social personal data, it is impossible to identify a person and to determine the level of his or her legal personality. In order to improve providing the legal personality personification of an individual, we suggest following classification: nominative personal data of an individual, which are the surname, name, patronymic, date of birth, etc. as a basic condition for their classification, and also variable personal data of an individual - education, marital status, place of residence, etc., through which the content of information about a person is established, the possibility of a clearer identification of the individual in the "legal field" is achieved. Nominative personal data is static. Its purpose is to identify initially a subject based on his or her general characteristic.

Variable personal data can accumulate or change under the influence of reality, for example, to the passage of time. Consolidating with a nominative, they contribute to the achievement of the goal of personification of an individual. Exactly this information provides the ability of data about an individual to flow.

\section{CONCLUSIONS}

Consequently, the notion "personal data" should be understood as the data of a person who is identified or can be identified on the basis of this data or additional information that may fall into the controller of the data and which contain expressions of attitude towards that person and an indication of a particular purpose or plans for this person from the person controlling the data or another person. Current national legislation defined the notion of personal data: information or collection of information about the physical person who is identified or can be specifically identified. Social significance, participation in legal relations, with regard to the flow of this information, of a specific subject - the organiser of public information defines whether information belongs to the public category. Contents of the public information may constitute information, regardless of the sectorial belonging and type, resulting from the information activities of the authorities or other public information managers. Information providers of public information are subjects of power, legal entities, financed from state and local budgets, persons performing delegated powers, as well as economic entities. Information and legal status of public information providers, procedure of giving access to public information, which may be the subject of further research in this direction, require separate analysis.

In the research, legal classifications of types of information about an individual were analyzed. The matter of classification was researched by different scientists. 
The author identified that considered classification has a cross-sectorial nature, since the above listed personal data are systematised for the purpose of its use, including in the public law field (tax law, forensics, etc.). That is why in the author's opinion it is methodologically unacceptable. We consider erroneous to combine law phenomenon that have different fields of application, as well as the method of legal regulation of legal relations, in which they become the object of law, or legal means of their regulation.

Enforcing the right of an individual related to the processing of their personal data with the help of an effective institutional and legal mechanism should become the purpose improving the protection of personal data in Ukraine. Legal basis of personal data protection defined by framework law needs to be adapted to EU legal norms and further significant improvement.

\section{REFERENCES}

[1] Law of Ukraine "On Protection of Personal”. (2010). Retrieved from https://zakon.rada.gov.ua/laws/show/2297-17

[2] Law of Ukraine “On Information”. (1992). Retrieved from https://zakon.rada.gov.ua/ laws/show/2657-12

[3] Halfina, R. O. (1974). General theory of legal relations. Moscow: Yuridicheskaya literatura.

[4] Davidova, N. O. (2008). Personal non-property rights. Kyiv: In Yure.

[5] Nohrina, M. L. (2004). Civil law regulation of personal non-property relations, not related to property. Saint Petersburg: Izdatel'stvo V. Aslanova Yuridicheskiy tsentr Press.

[6] Ustimenko, N. V. (2003). Civil law protection of secrets of personal life of a person. Kharkov: PP Ton-Art.

[7] Krasavchikova, L. O. (1994). The concept and system of personal non-property, nonproperty rights of citizens (individuals) in the civil law of the Russian Federation. (Doctoral dissertation, Ural State Law Academy, Ekaterinburg, Russian Federation).

[8] Kechekyan, S. F. (1958). Legal Relations in a Socialist Society. Moscow: Publishing House of the Academy of Sciences of the USSR.

[9] Kulinich, O. O. (2006). Restricted information as an object of civil law. (Candidate thesis, Odessa, National University "Odessa Law Academy”, Odessa, Ukraine).

[10] Afanasyev, V. G. (1994). Social information. Moscow: Nauka.

[11] Bachilo, I. L., Lopatin, V. N., \& Fedotov, M. A. (2001). Information law. St. Petersburg: Yuridicheskiy tsentr Press.

[12] Kopylov, V. A. (1997). Information as an object of legal relations in the systems of private and public law. Scientific and Technical Information, 9, 1-17.

[13] Petrykina, N. I. (2011). Legal regulation of the circulation of personal data. In N. I. Petrykina (Ed.), Theory and practice (pp. 18-29). Moscow: Statut, 2011.

[14] Ishcheynov, V. Ya. (2006). Personal data in legislative and regulatory documents of the Russian Federation and information systems. Office Work, 3, 90.

[15] Berg, N., \& Kim, J.-Y. (2018). Free expression and defamation. Law, Probability and Risk, 17(3), 201-223.

[16] Goodman-Delahunty, J., \& Martschuk, N. (2018). Securing reliable information in investigative interviews: coercive and noncoercive strategies preceding turning points. Police 
Practice and Research. Retrieved from https://www.tandfonline.com/doi/full/10.1080/15 614263.2018.1531752

[17] Vrij, A., Meissner, C. A., Fisher, R. P., Kassin, S. M., Morgan, C. A., \& Kleinman, S. M. (2017). Psychological perspectives on interrogation. Perspectives on Psychological Science, 6, 927-955

\section{Hans Joachim Schramm}

Institute of Eastern Law

University of Technology, Business and Design

23966, 14 Philipp-Müller-Straße, Wismar, Germany

\section{Anatoly V. Kostruba}

Doctor of Law, Associate Professor, Professor

Department of Civil Law

Vasyl Stefanyk Precarpathian National University

76018, 57 Shevchenko Str., Ivano-Frankivsk, Ukraine

Suggested Citation: Schramm, H. J., \& Kostruba, A. V. (2019). Legal classification of types of information about an individual. Journal of the National Academy of Legal Sciences of Ukraine, 26 (1), 123-132.

Submitted: 09/01/2019

Revised: 05/02/2019

Accepted: 28/03/2019 


\title{
ДОКАЗИ І ДОКАЗУВАННЯ: ПРО ТЕНДЕНЦІї УДОСКОНАЛЕННЯ КРИМІНАЛЬНОГО ПРОЦЕСУААЬНОГО ЗАКОНУ
}

Анотація. Існування в кримінальному прочесі факту, порушення прав та свобод людини, а також можливих зловживань зі сторони органів, які безпосередньо проводять досудове розслідування дає підстави для наукового вивчення зазначеної теми. Такі дії повинні чітко врегульовуватися законодавием в кримінальному процесуальному законодавстві. Тому основна мета роботи полягає в аналізі доказів і доказування, які сприятимуть удосконаленню кримінального прочесуального закону. Для досягнення поставленої мети були використані методи аналізу, філософського вчення, пізнавально-практичні. Встановлено, щзо відсутність єдиного підходу до інституту допустимості доказів викликає дискусію навколо питання про можливість прийняття процесуальних рішень у кримінальному провадженні на підставі доказів, отриманих з порушенням процесуальної форми, та про юридичну силу таких доказів, тобто щодо того, чи мають вони доказове значення. Аналіз лише деяких із масиву запропонованих за останні роки законопроектів, метою яких $\epsilon$ визначення удосконалення кримінального процесуального закону, ефективне виконання загальних завдань кримінального провадження, захист прав, свобод $і$ законних інтересів його учасників тощо, на жаль, засвідчує сумну тенденцію до прагнення змінити правозастосовну практику на краше лише засобами законотворчої діяльності без урахування системних проблем методологічного, правового та організаційного характеру. Серед причин такої ситуачії вбачаються і відсутність належного наукового обтрунтування відповідних змін (або ігнорування наявних наукових доробок), суперечливість у теоретичному, методологічному розумінні відповідних категорій, відсутність системного підходу до окремих напрямів реформування з урахуванням не лише суто правових, прочесуальних аспектів, а й організаційних. Виявлено, щзо вплинути на об'єктивний стан речей $і$ процесів неможливо лише засобами законотворчої діяльності, без належного методологічного підгрунтя, системи адміністративно-управлінських та організаційних заходів.

Ключові слова: правовий інститут, досудове розслідування, кримінальний проступок, конфіскація.

\author{
Victoria V. Rozhnova \\ Department of Criminal Process \\ National Academy of Internal Affairs \\ Kyiv, Ukraine
}

\section{EVIDENCE AND PROOF: TRENDS IN THE IMPORVMENT OF THE CRIMINAL PROCEDURAL LAW}

\begin{abstract}
In the criminal proceedings, the fact of violation of human rights and freedoms, as well as possible abuses from the part of the bodies that directly conduct a pre-trial investigation, provides grounds for the scientific study of this topic. Such actions have to be clearly regulated
\end{abstract}


by a legislator in criminal procedural law. That is why, the main purpose of the work is to analyse evidence and proof, which contribute to the improvement of criminal procedural law. To achieve this goal, analysis method, philosophical doctrine and cognitive and practical were used. It has been determined that the absence of one approach to the institute of admissibility causes the discussion concerning the question about an opportunity to adopt procedural decisions in criminal proceeding on the basis of evidence obtained in violation of the procedural form, and about legal effect of such evidence, that is, whether they have proof meaning. It has been revealed that it is impossible to affect objective status of thing and processes only by means of legislative activity, without needed methodological foundation, system of administrativemanaging and organisational means.

Key words: legal institution, pre-trial investigation, criminal offence, confiscation.

\section{INTRODUCTION}

The extensive process of reforming of criminal procedural legislation in Ukraine that began as a part of implementation of the Concept of Judicial and Legal Reform in Ukraine (1992) [1], continued within the implementation of the Concept of Reforming the Criminal Justice of Ukraine (2008) and formally culminated with the adoption of the Criminal Procedure Code (hereinafter referred to as the CPC) on April 2012, but in fact the process has been lasting until today.

Perhaps, it is not that extensive, but reforming of the domestic criminal procedural legislation has become constant in the modern legal system of Ukraine. Seemingly, it may be commended as necessary and quick response of legislator to changes in respective public relations and to objective needs of law enforcement subjects in this sphere [3;4]. However, in 2015, in the Strategy for reforming the judicial system, justice and related legal institutes for 2015-2020, the status of the justice, functioning of the prosecutor's office and the criminal justice as adjacent legal institutes, is assessed as having disadvantages, conditioned by problems in the field of strategic planning and in the legislative process, and by absence of systematic view in the formation of the justice sector democratisation in long, middle and short term [5].

The main source of criminal procedural law is the current CPC that has been in effect since November 20, 2012. Although first amendments had been made on July 5, 2012 [6], that is, before it entered into force. In the years since, each year the CPC of Ukraine (sometimes along with other sources of criminal procedural law of Ukraine) has been amended, supplemented [7].

In general, in a certain way the CPC of Ukraine has been amended by more than 55 laws of Ukraine. Some of them changed normative regulation of certain procedure acts (for instance, of the Temporarily Takeover and search) or introduced procedural mechanisms for the implementation of new criminal law institutes (for example, special confiscation [8]), and some made systemic changes to the normative regulation of criminal procedural activities and its implementation by individual participants of criminal proceedings or at individual stages of the process (for example, Regulation of the Criminal Court of the Supreme Court as a court of cassation [9]). 
Separate articles of the CPC of Ukraine for six years of its operation have been repeatedly amended. Thus, art.170 of the CPC of Ukraine has been amended six times (by laws of Ukraine dated April 18, 2013, May 23, 2013; February 12, 2015, November 10, 2016, February 18, 2016), art. 236 of the CPC of Ukraine has been amended four times (by laws of Ukraine dated May 13, 2015, November 10, 2015, October 3, 2017, November 16, 2017) [7].

In this, some articles of CPC of Ukraine have been amended during short periods (for example, articles 170, 174 were amended by laws of Ukraine dated April 18, 2013, and May 23, 2013, article 303 - by laws of Ukraine dated October 3, 2017 and November 16, 2017).

Separate provisions of the CPC that had been amended, after a while were amended again. Thus, for example, wording of p.2 art.132, first paragraph of p.1 art.184, p. 2 art. 234 of CPC of Ukraine at first was amended by law of Ukraine dated October 3, 2017, but respective provisions have been returned in fact to the first version by the law of Ukraine "On Amending the Criminal procedure Code of Ukraine concerning clarification of separate provisions", due to the fact that the changes made by the law of Ukraine dated October 3, 2017 ", greatly complicated the work of the pre-trial investigation bodies in terms of the prompt, complete and impartial investigation" [10].

\section{MATERIALS AND METHODS}

The matter of the improvement of the legislation in the sphere of criminal procedural proof has always been at the centre of the criminal proceeds science. This question regarding recognition of the rights of participants in the process for the independent evaluation of evidence, in particular, the evaluation of evidence as one of the elements of the criminal procedural proof that is significant for the judicial and investigative activities, is actual $[11 ; 12]$. Use of different theoretical methods revealed the features of logical interpretation of cognitive evidentiary activity. They are:

- firstly, the distinction of cognitive (and) practical and justifying (logical) activities as separated from each other in time; the first one precedes the second one and, according to the certain scientists, is not included to the content of proof, just provides it;

- secondly, understanding to proof the establishment of "practical truth", which is considered as certain degree of reliability of knowledge about a committed criminal offence;

- thirdly, the understanding as evidence the facts, using which establishes other (evidentiary) facts;

Analyses method revealed that pre-Soviet scientists in the understanding of evidence placed emphasis on the content part, but not on the form of evidentiary facts fixation. The other aspect of the understanding of the essence of cognitive criminal procedural proof activity can be called rational and empirical, when knowledge is obtained through direct or indirect perception using certain mental logical operations and correlates with 
experience (as proof inherent to certain subject and to the society in the whole) [13]. It is characteristic for the most of scientific works from the beginning of 20th century and to this day. Despite the fact that in different periods of historic development this interpretation was affected by different philosophical doctrines (which in theory basis, as a rule, had dominant in a state and society ideological component), the main its sense (rational and empirical) has always been decisive that let us highlight it.

Systematic approach provided an opportunity that search for solution of any problem should be systematic, that is, it is needed to consider the whole system, in which a problem has appeared, taking into account all purposes and functions of the system, structure, all the internal and external relations. Systematic approach is the basis of such applied scientific discipline as systematic analysis, which is aimed at development of methods of analysis of systems and solution of its problems [14]. In the procedure of proof activity, the main evidence is the most important and decisive. Law provides an opportunity to substantiate legal positions of parties and court and court's decision only with evidences gained in a framework of trial communication of its participants. Considering the great value of such evidences for the criminal proceeding, the necessity to distinct these evidences from evidences, gained on pre-trial evidence proceeding and the historical traditions, in our opinion, they can be called "trial evidence". Exactly in such way, we suppose, this discussion matter can be solved in the proof theory. The structure of the proof theory consists of two sections: general that describes general knowledge about definitions and types of evidences and process of proof, and special, which is about peculiarities of gathering, examining, evaluation, check and use of evidence during investigation (search) or proof during trial.

\section{RESULTS AND DISCUSSION}

Some Ukrainian laws, by which also articles of the CPC of Ukraine had been amended, later were repealed by other Ukrainian laws (thus, the law of Ukraine dated January 28, 2014, repealed the law of Ukraine dated January 16, 2014, "On Amendments to the Criminal Procedure Code of Ukraine regarding extramural criminal proceedings", the law of Ukraine dated January 16, 2014, "On Amendments to the Law of Ukraine "On the Judicial System and Status of Judges" and procedural laws concerning additional measures in order to protect citizens' safety"), and separate provisions of the CPC pf Ukraine (including those, which are amendments/supplements) were overturned as unconstitutional (thus, the law of Ukraine dated December 21, 2016, had supplemented article 216 of the CPC of Ukraine with part six, which later by the decision of the Constitutional Court of Ukraine dated April 24, 2018, No 3 was overturned unconstitutional) [15].

Decidedly, such situation has affected quality of criminal proceedings law. According to a fair statement of $\mathrm{O}$. A. Leiba, spontaneous and situational normative dynamics of criminal proceedings legislation of the last years have led to the aggravation of normative and content issues that for five years have been "painful" for the law enforce- 
ment and still have not been solved. Moreover, they create new issues, which intensify inconsistency of separate structural elements of criminal procedure legislation or create mutual confrontation between some norms; cause mistakes in setting structural connections using blanket and reference norms; condition violation of law logic in construction of terminology and conceptual categorical apparatus, etc. [16].

Legislative drafting of out parliamentarians aimed at the improvement of the current CPC of Ukraine even for today is very active. However, unfortunately, not all draft laws proposed for consideration or even those ones adopted by Verkhovna Rada of Ukraine and entered into force, really contribute to the achievement of the declared goal. In connection with this, there are new grounds for a critical analysis of the next improvement of (attempts to improve) the criminal procedural law, both from the point of view of compliance with the rules of legislative technique, and in view of the effectiveness of the normative regulation of criminal procedural activities, taking into account the legal and organisational aspects of its implementation.

Thus, there is number of questions about the results of the text analysis of the draft of the Law on Amendments to Certain Legislative Acts of Ukraine on the Simplification of Pre-trial Investigation of Certain Categories of Criminal Offences (№ 7279 dated April 20,2018) in wording dated November 21, 2018, that was adopted by Verkhovna Rada of Ukraine [17].

This draft law proposes amendments, in particular, to the CPC of Ukraine, insofar as it concerns the peculiarities of pre-trial investigation in the form of criminal misdemeanour investigation, a list of which is defined in the amendments to the Criminal Code of Ukraine (in the wording of the same draft), as well as the peculiarities of trial of the criminal proceedings regarding criminal offences.

Without denying, in general, the urgent need for the adoption and implementation of a law that would provide the material basis and consolidate the procedure for differentiating the criminal procedural form towards the simplification of pre-trial investigation and judicial consideration of certain categories of criminal offences, nevertheless, we note that the draft was criticized, first of all from the Main Scientific Expert Department and the Main Legal Department of the Verkhovna Rada of Ukraine. Along with this, reading the text of the draft gives grounds for additional thinking and critical conclusions.

Thus, among other things, attention is drawn to the efforts of the authors of the draft to establish the features not only of the procedure of pre-trial investigation in the form of enquiry and judicial review of criminal proceedings concerning criminal offences, but also to change the general provisions of the criminal proceedings, the basic concepts of criminal procedural law.

This can be concluded from the analysis of article 298-1 of the draft, which establish the extended list of procedural sources of evidence (in compare with article 84 of the CPC of Ukraine) in criminal proceedings about criminal offences and also the general prohibition on the use of the latter in a criminal proceeding concerning a crime. 
Such approach conditions the appearance of the number of questions, answers to which are absent in the text of the draft and in the accompanying documents: do the evidence that are gathered during the pre-trial investigation, by their legal nature is different from the evidence that will be gathered during the enquiry? Should the admissibility of evidence (in particular, in the question of the legality of their procedural source) to be resolved differently in pre-trial investigation and enquiry? Should the source, which is not recognised as a source of evidence in a pre-trial investigation, be recognised as a source of evidence in an enquiry? And on the contrary, the source, which is recognised as a source of evidence in an enquiry, should not be recognised as a source of evidence of pre-trial investigation, but nevertheless, in some cases, be recognised by a decision of an investigating judge?

Also, there is a question concerning the content of the decree of an investigating judge, and concerning judge's power to assent use of procedural sources of criminal proceeding about criminal offence in criminal proceeding concerning a crime (par.3 p. 1 art. 298-1 of the draft). What should be a factual ground and condition to adoption of such decision by investigating judge?

It is worth noting that all proposed in art.298-1 additional procedural sources, in particular: explanation of persons, results of medical examination, expert's report, testimony of technical devices and technical means, which have a function of photo and film, video recording or photographic and cinematographic equipment, video recording, can be used (and are being used) in proof as a "classical" source of evidence - documents.

\section{CONCLUSION}

Ways of gathering evidence is also under reforms. As a result, the spectrum of evidence for the prosecution in criminal proceedings for a criminal offence is wider than in a criminal proceeding of a crime (Article 300 of the draft, Article 93 of the CPC of Ukraine). Expect investigation (search) provided by the CPC of Ukraine, in criminal proceedings for a criminal offence a number of "other actions" may be conducted resulting in formation of procedural sources of evidence implied by art.298-1 (which as well may be can be conducted before entering into the Uniform Register of Pre-trial Investigations and by decision of investigating judge become sources of evidence in criminal proceeding about a crime).

However, along with this, unlike investigative actions, the procedure for conducting "other actions" in criminal proceedings for a criminal offence has not actually been established. How should the admissibility of the evidence obtained as a result of such actions be resolved (in particular, in the question of observance of the procedure for obtaining them in accordance with the law)?

In general, it is worth noting that analysis of only a few of the drafts proposed in recent years, a purpose of which is to determine the improvement of criminal procedural law, effective fulfillment of general tasks of criminal proceedings, protection of 
rights, freedoms and legitimate interests of its participants, etc., unfortunately, shows a sad tendency of changing law enforcement practice for the better only by means of legislative activity without taking into account systemic problems of a methodological, legal and organisational nature.

Among the reasons of this situation are the absence of necessary scientific foundation of respective changes (or ignoring existing scientific developments), the contradiction of theoretical, methodological understanding of respective categories, the absence of systematic approach to the separate directions of reforming with taking into account, not only legal, procedural aspects, but also organisational.

\section{REFERNCES}

[1] The concept of judicial reform in Ukraine, the adopted by the Verkhovna Rada of Ukraine on April 28, 1992. Retrieved from https://zakon.rada.gov.ua/laws/show/2296-12

[2] The concept of reforming the criminal justice of Ukraine: declared by decree of the president of Ukraine dated April 8, 2008. Retrieved from http://pravo.org.ua/ua/news/2491-

[3] Kennedy, J. (2019). The Citizen Victim: Reconciling the Public and Private in Criminal Sentencing. Criminal Law and Philosophy, 13(1), 83-108.

[4] Mirică, S.-C., Gavrila, S. P., Matic, A. E., \& Moga, L. M. (2019). Duties of the special administrator in the insolvency procedure. In Proceedings of the 32nd International Business Information Management Association Conference, IBIMA 2018 - Vision 2020: Sustainable Economic Development and Application of Innovation Management from Regional expansion to Global Growth (pp. 3253-3261). Spain: IBIMA.

[5] Strategy for reforming the judicial system, justice and related legal institutes for 2015-2020: approved by the Decree of the President of Ukraine dated May 20, 2015. No.276. Retrieved from https://zakon.rada.gov.ua/laws/show/276/2015

[6] On advocacy and advocacy: the law of Ukraine dated July 5, 2012. Retrieved from https:// zakon.rada.gov.ua/laws/show/5076-17

[7] The criminal procedure code of Ukraine. Retrieved from https://zakon.rada.gov.ua/laws/ show/4651-17

[8] On amendments to the criminal and criminal procedural codes of Ukraine to implement the action plan for the European Union liberalization of the visa regime for Ukraine: the law of Ukraine dated Otober 3, 2017. Retrieved from https://zakon.rada.gov.ua/laws/ show/222-18

[9] On amendment of the commercial procedure code of Ukraine, civil procedure code of Ukraine, code of administrative procedure of Ukraine and other legislative Acts: the Law of Ukraine dated October 3, 2017. Retrieved from https://zakon.rada.gov.ua/laws/show/ $2147-19$

[10] The explanatory note to draft law "On amendment of the commercial procedure code of Ukraine, civil procedure code of Ukraine, code of administrative procedure of Ukraine and other legislative acts". Retrieved from http://search.ligazakon.ua/1_doc2.nsf/link1/ GH6AF00A.html.

[11] Liebenberg, S. (2018). Participatory justice in social rights adjudication. Human Rights Law Review, 18(4), 623-649.

[12] Ambos, K. A. I. (2018). International economic criminal law. Criminal Law Forum, 29(4), 499-566. 
[13] Karatzia, A. (2018). Revisiting the Registration of European Citizens' Initiatives: The Evolution of the Legal Admissibility Test. Cambridge Yearbook of European Legal Studies, 20, 147-178.

[14] Adams, C. (2018). Home rules: The case for local administrative procedure. Fordham Law Review, 87(2), 629-669.

[15] The decision of the Constitutional Court of Ukraine in the case upon the constitutional petition of the Ukrainian Parliament Commissioner for Human Rights on the compliance of the provisions of paragraph 6 of Article 216 of the Criminal Procedure Code of Ukraine with the Constitution of Ukraine dated April 24, 2018, No 3-r/2018. Retrieved from https:// zakon.rada.gov.ua/laws/show/v003p710-18

[16] Leiba, O. A. (2018). Defects of criminal procedural legislation and ways to overcome them. Kharkiv: "Urait".

[17] The draft law on amendments to certain legislative acts of Ukraine on the facilitation of pre-trial investigation of certain categories of criminal offenses, reg. No. 7279-d dated April 20, 2018 (text of the draft to the second reading with changes dated November 21, 2018) / Verkhovna Rada of Ukraine: official web portal. Retrieved from http:/w1.c1.rada.gov.ua/ pls/zweb2/webproc4_1?pf3511=63928.

\section{Victoria V. Rozhnova}

Candidate of Juridical Sciences, Assistant Professor

Professor of the Department of Criminal Procedure

National Academy of Internal Affairs

03035, 1 Solomjanska Sq., Kyiv, Ukraine

Suggested Citation: Rozhnova, V. V. (2019). Evidence and proof: trends in the imporvment of the criminal procedural law. Journal of the National Academy of Legal Sciences of Ukraine, 26 (1), 133-140.

Submitted: $18 / 01 / 2019$

Revised: 20/03/2019

Accepted: 28/03/2019 
УДК 343.142

DOI: 10.31359/1993-0909-2019-26-1-141

Оксана Кузьмівна Тугарова

Кафедра організації захисту інформаиії з обмеженим доступом Навчально-науковий інститут інформаційної безпеки Національної академї Служби безпеки України Київ, Україна

\section{ЛОГІЧНА ПРИРОДА НЕПРЯМИХ ДОКАЗІВ У КРИМІНАЛЬНОМУ ПРОЦЕСІ}

Анотація. Необхідність реформування кримінального законодавства Украйни зумовлена економічними, політичними та соціальними змінами в нашій державі. Робота має на меті дослідження логічної природи непрямих доказів, з'ясування особливостей їх структури та правил побудови, а також визначення типових логічних помилок, які можуть мати місие при доказуванні обставин вчиненого злочину. На підставі аналізу наукової літератури розкрито логічну структуру непрямого доказу, охарактеризовано їх види, виокремлено типові логічні помилки, щчо можуть мати місие при доказуванні фактів і обставин вчиненого злочину за допомогою непрямих доказів. Встановлено, щз поняття доказу в системі наукових знань використовується як в широкому розумінні, так і у вузькому, стосовно конкретної галузі наукової діяльності. У логіиі виділяють два види непрямих доказів: апагогічний $i$ розділовий, які виступають єдиним засобом встановлення істинності певного твердження. При цьому слід враховувати, щзо логічне поняття непрямих доказів не збігається зі змістом поняття непрямого доказу у науці кримінального процесу. Цим пояснюється подвійна сутність процесуальних непрямих доказів: стосовно часткової тези вони є прямими доказами і самостійними засобами доведення ї̈ істинності або хибності; щуодо до основної, або узагальнюючої тези - непрямими доказами, які лише у сукупності з іншими можуть доводити ії істинність або хибність. 3 логічного боку непрямим доказом у кримінальному процесі є аргумент часткової тези, яка в подальшому виступає аргументом основної тези. Цим пояснюється подвійна сутність процесуальних непрямих доказів: стосовно часткової тези вони є прямими доказами і самостійними засобами доведення ії істинності або хибності; щзодо до основної, або узагальнюючої тези - непрямими доказами, які лише у сукупності з іншими можуть доводити ї̈ істинність або хибність. Доведення існування (неіснування) фактів і обставин, щзо мали місце в минулому, відбувається у формі умовиводу. Побудова умовиводу не виключає можливості логічних помилок, які мають місие і при доказуванні обставин вчиненого злочину за допомогою непрямих доказів.

Ключові слова: доказування, непрямий доказ, умовивід, логічні помилки.

Oksana K. Tugarova

Department of Organization of $\rho_{\text {rotection the Restricted Access Information }}$ Educational and Scientific Institute of Information Security of

National Academy of the Security Service of Ukraine

Kyiv, Ukraine

\section{THE LOGICAL NATURE OF INDIRECT EVIDENCE IN CRIMINAL PROCEDURE}

Abstract. The necessity of reforming the criminal legislation of Ukraine is caused by economic, political and social changes in our state. That is why the article is devoted to the research 
of the logical nature of indirect evidence in criminal procedure. Based on the analysis of scientific literature the logical structure of indirect evidence has been revealed, its types have been characterised, it has been determined the typical logical errors, which may be in facts proof and circumstances of committed crime using indirect evidence. It has been determined that the definition of evidence in the system of scientific knowledge is used both in the wide sense and in the narrow, in relation to a specific field of scientific activity. In logic two types of indirect evidences are highlighted: apagogical and assumption proof, which are the single method to discover the truth of certain statement.

Key words: proof, indirect evidence, reasoning, logical errors.

\section{INTRODUCTION}

Deep socio-political and economic transformations in Ukraine have affected the nature of criminality. It has become more professional and organised. Much of the crimes is being committed in abeyance. Opposition to the investigation and solution of crime is growing: its traces are suppressed and destroyed, documents and things, which may be evidences in criminal case $[1 ; 2]$. This limits the possibility of using direct evidence to establish facts and circumstances of commission of a crime and necessitates the involvement of indirect evidence in the process. However, in the current criminal procedure legislation, there are no regulations regarding indirect evidences and conditions for their use in the process of proof [3]. That is why executors of law are guided by appropriate fragmentary knowledge of academic and scientific literature.

At different times L. E. Vladimirov, M. M. Vidrya, V. P. Gmyrko, Yu. M. Groshev, V. Ya. Dorokhov, P. S. Elkind, L. D. Kokoriev V. K. Lisychenko, Ye. D. Lukyanchikov, P. A. Lupinskaya, M. M. Mikheenko V. T. Nor, M. A. Pogoretsky, M. M. Rosin, V. D. Spasovich, M. S. Strogovich, V. T. Tertishnik, A. I. Trusov, F. N. Fatcullin, I. Ya. Foynitsky, M. O. Cheltsov-Bebutov, S. A. Sheifer, M. E. Shumilo and other researches devoted their works to the issue of evidence and proof in criminal proceeding. However, in the works of mentioned scientists, the issue of indirect evidence was researched mostly secondary, in connection with the coverage of other aspects of evidence law. A. I. Vinberg, M. M. Grodzinsky, O. O. Eysman, V. I. Kaminskaya, G. M. Minkovsky, R. D. Rahunov, M. P. Shalamov, O. O. Hmyrov devoted their works exclusively to the issue of indirect evidence. They formulated a number of important ideas that were used effectively in the course of criminal investigations for a long time. However, the mentioned works were created predominantly until the mid-80-ies of the last century, and later the theoretical development of this topic has slowed down [4]. The loss of scientific interest in the issue of indirect evidence is not justified, as in modern science of the criminal process, there remain a number of controversial and unexplored issues that need to be resolved for their proper understanding and unambiguous application in practice. Thus, the questions regarding the notion of indirect evidence and possibility and 
expedience of their classification in criminal procedure are controversial; logical nature of indirect evidence is also underexplored [5]. Legislative gaps and controversy of above-mentioned questions in the theory of criminal procedure do not contribute to effective usage of indirect evidence in court and investigative practice and necessitates modern scientific development of the issue of indirect evidence in the domestic criminal procedure.

This work is aimed at researching the logical nature of indirect evidence in court and investigative practice, finding out the features of its structure and construction rules, as well as determining the typical logical errors, which may be in proof of the circumstances of the crime.

\section{MATERIAL AND METHODS}

The main goal of evidence theory is obtaining and deepening knowledge regarding improving evidence law and process of proof. Using analysis method it was revealed that evidence theory colligates system of knowledge and disclosers the notion and its content, content of truth and content of fact to be proven in criminal procedure; patterns of determination of criminal offence in objective reality and formulation of crime tracks and other proof information; notion and types of evidence; patterns of formation and storage of evidence; the essence of requirements of affiliation to a case, admissibility and reliability of evidence; features of material evidence, documents, testimonies, findings of expert and other evidence; features of process of prof, principle of evidence law; content, form and order of gathering, researching, check, evaluation and use of evidence; purpose and means to ensure documentation of proof activity; use an operative-investigative operations and their results in proof; guarantees of protection of human rights and freedoms and legal entities in the course of proof; guarantees of protection of human rights and freedoms and legal entities in the course of proof; features of handling evidences during public investigative and secret investigative (search) actions; legal positions and case law of the European Court of Human Rights on issues of proof in criminal proceedings; features of practical activity of the investigation authorities, prosecutor, counsel, court and other participants in the process of proof at various stages of criminal proceedings; features of proof in a jury and other special forms of the criminal procedure; features of evidence law of foreign countries; state of the main problems and tendencies in the development of evidence theory and ways to improve evidence.

While disclosing mentioned aspects of criminal process, evidence theory shows the ways to improve both the legislation and activity of investigative and judicial bodies, contributes to balanced application of effective means of proof and warns of possible legal errors. As in any scientific study, in evidence theory there is need for empirical knowledge - knowledge of certain empirical facts and their interrelations. An 
object, which has an infinite set of properties and relations - external manifestations of its essence, is reflected in many facts that, after being discovered, are part of the empirical basis of science. Epistemologically, facts are valid knowledge, which is obtained by describing the individual fragments of reality in a particular spatialtemporal intervall.

The basis of evidence theory is evidence law. Evidence law includes norms that determine: a) purpose and fact to be proven; b) notion and types of evidence; c) requirements of admissibility of evidence; d) principles of evidence law; e) content and components of the process of proof; f) ways of proof, system of investigative and other cognitive and proof actions.

Analysis and comparison methods have revealed that in legislation and practical activity there is many unsolved problems, part of which will be analysed in this article.

\section{RESULTS AND DISCUSSION}

The notion "evidence" is one of the central in any sphere of scientific and practical activity. In the process of world cognition, clarifying the properties of individual objects, people form certain ideas about objects. During exchange of thought about an object, it is spread that formed ideas of one do not correspond to views of other, and there is need for defending own rightness, refuting the positions of the opponents, that is, in substantiating and proving the correspondence of own ideas and knowledge to objects and phenomena of reality. Ways of obtaining knowledge, which provide adequate representation of surrounding reality, are evidences.

To prove, i.e. to use evidence as means of grounding of the truth or falsity of a particular position, is necessary in all spheres of scientific activity. However, determining the notion of evidence in various fields of scientific knowledge has different content. In general scientific sense, evidence is certain mental process, when a truth of a certain statement is deduced from the statements already recognised as true. In such way evidence is explained in logic (Gk. logos - word, notion, mind) - the science about the rules and operations of correct thinking. In a similar way philosophy explains the notion of evidence. The analysis of scientific publications that generalise views on the notion of evidence indicates the coincidence of the concepts of proof (proving) and evidence. The latter is defined as logical form of establishing the truth of one or another though on the basis of knowledge, the truth of which is indisputable [6].

Unlike mentioned sciences, where mental process is evidence, aiming at grounding a certain statement, there is number of fields of scientific knowledge, which explain the notion differently. Thus, in mathematical sciences the evidence is the finite sequence of formulas, each of which is either an axiom (Gk. axioma - universally meaningful), that is condition adopted without proof, or derived from the previous formulas of sequence according to the rules of reasoning [7]. In the sciences, which research chronologically the human society and the patterns of its development (archeology, history, historiography), evidence is equated: firstly, with the way of obtaining new knowledge 
about a new fact; secondly, with the way, by which it is confirmed or denied that gained knowledge corresponds to reality [8].

The notion of evidence is one of the central in jurisprudence, because "it is doubtful there is any other branch of human activity, in which knowledge and proof of truth would have been so acute in terms of the emotional tension of perception and the so immense in terms of significance of social consequences, as is the case with the justice" [9].

Learning facts, mental restoration and modeling of the picture of the event that took place in the past, are carried out with the help of evidence. As in historical sciences, in jurisprudence, evidences are certain facts (information about facts, factual data), by which presence or absence of a researched event and circumstances, that are interrelated with it, are established and substantiated. Thus, evidences are received in the established order factual data that contains information necessary for solution of a criminal, civil, economic, constitutional and other court cases. The process of obtaining evidences and using them with the purpose to reproduce the investigated event is called proof. In such way, the notion of evidence in the system of scientific knowledge is being used both in wide and narrow sense in relation to specific field of scientific activity. In the wide sense evidence is equated with a mental process, in course of which individual objects, existence of interrelations between events or phenomena is logically established or refuted. In more narrow sense it is about mathematical, historical, court evidences as about ways to establish or refute certain statement or condition. All of them have respective content differences, in which their specificity and individuality are reflected.

General doctrine about evidence, its structure and conditions of logical perfection is the subject of study of logic. It is characteristic that logic does not research content features of evidence in different fields of science, that is "researches only that is universal (general) regardless of specific features of their separate content" [10].

Modern formal logic highlights in evidence three main components: thesis, argument and demonstration. The thesis (Gk. thesis - statement) is a statement, truth of which is being grounded in evidence, that is statement, truth of which has to be substantiated (proven). The thesis is the main element of evidence, the whole process of proof is directed to its substantiating. Exactly "thesis takes the same place in the proof, which is given to the king in chess. No matter how proof was built, which facts and events would have been analyzed, which parallels and analogies would have been, in the focus of attention the task should always remain - the substantiating of the above thesis and the refutation of antithesis" [11].

There is the main and partial thesis. The main thesis is a statement that is subject to final substantiation by number of statements. The partial thesis is a statement that becomes the thesis at the intermediate stage of proof building. Both the main and partial thesis has to meet specific requirements, violation of which may lead to inconsistency or incorrectness of the logical proof. These requirements include the following: 
a) Only those statements, which really require substantiation under specific conditions, may be the thesis;

b) The thesis has to be clearly defined statement;

c) The thesis has to remain unchanged throughout proof;

d) There has not to be logical contradiction in the thesis [12].

The ways to confirm or refute thesis are arguments - statements (arguments), on the basis of which the truth (falsity) of the main or partial thesis is established. Arguments, or, as they are called, evidence grounds also have to meet clear requirements, namely:

a) To be true statement;

b) To be statement, truth of which is established regardless of the thesis;

c) To have enough grounds for proving the thesis.

When exploring the concept of evidence from the logical side, one more element of its characteristics should be identified - the way for conducting proof or demonstration, which is a method of illustrating the connection between the thesis and arguments. The existence of such connection is the precondition of the correctness of building each proof. In the literature, devoted to researching of issues of proof logic, it is highlighted: "not all two statements can be combined in the act of proof, because not from any "one" logically follows the "second". This is possible only when there is certain objective connection between statements. From the fact of threatening it is possible to deduce the existence of intent and make an indirect conclusion about crime commission by this person. But it is pointless to conclude about a motive for crime basing on the colour of the suspect's hair" [13].

Depending on the way for conducting or demonstration of proof in logic there is direct and indirect evidences. In direct evidence truth (falsity) of the thesis follows directly from the true arguments, without assumptions competing with the thesis; building of indirect evidence is based on conflicting statements that exclude each other.

In logical also there are two types of indirect evidence: apagogical and assumption. Apagogical (Gk. apagögos - to pull aside) indirect evidence is the evidence, in which truth of the thesis is proven through establishing falsity of antithesis. Evidence of such type has two stages. In the first stage - «reductio ad absurdum» (reduction to absurdity) - falsity of antithesis is being substantiated. Initially, instead of the arguments that directly confirm the truth of the thesis, the truth of the opposite judgment - antithesis - is temporarily admitted. Further, from this antithesis, conclusions are drawn that contradict reality. The result is a contradiction. In the second stage, on the basis of the law of the excluded middle - the logical law, according to which true is either statement or its denial, it is deducted that the antithesis is false and the thesis is the truth. For 
example, suspect A states that in a day of crime commitment he took part in a scientific conference in another city, accordingly, he could not commit it. In such case, statement A is the thesis, the truth or falsity of which it is necessary to prove. In the first stage, it is argued that A was not at a conference in another city, so he had an opportunity to commit a crime. From this antithesis is deduced: A did not speak with a scientific report to a large number of audiences in another city; did not recorded in a book of hotel guests; did not indicate arrival in another city. Because of that these facts were established and they took place in reality, on the basis of the law of the excluded middle, person cannot be at the same time in two places - it is deducted: A really was at a scientific conference in another city. In the second stage, it is deducted that antithesis - suspect A was not at a scientific conference is false, therefore, his testimony about staying in other place corresponds to reality.

Apagogical indirect proof is often the way to achieve the truth of knowledge in scientific and practical activities of people. In many fields of science, it is called "proof from the contrary". However, the other type of indirect evidence assumption evidence - is not less important. Unlike the apagogical, in this type of evidence, antithesis is not building, but several theses are put forward, a number of which completely exhausts all possible alternatives regarding a particular question. Accordingly, in the process of building evidence, all alternatives, except one that is a thesis, are refuted. The demonstration of assumption indirect evidence is as follows: it is known that occurrence of certain occasion may be caused only by one of the three reasons - A, B, C. It is determined that neither $\mathrm{A}$, not B can cause this occasion. Therefore, the reason of occurrence is $\mathrm{C}$.

In cognitive activity of people, both apagogical and assumption evidences play the important role and often are the one means to establish truth of certain statement. Most human discoveries - the unravelling of the mysteries of ancient civilisations, the knowledge of the depths of space, the discovery of new chemical elements - was often carried out because of the impossibility of using obvious arguments. In such cases, researchers, basing on the laws of logic, used indirect way of proof, with which provided the reasonableness and provenance of their discoveries.

The division of evidence into direct and indirect is a traditional also for the science of the criminal procedure. However, such division differs from analogical classification of logical evidence, only the terminology is the same. Such discrepancy is due, at least, two factors. Firstly, in criminal procedure evidence is not a process of selection or search for grounds in favour of a certain thought, but a means to achieve the final goal of such a process. In other words, evidences in criminal procedure are arguments of logical proof. Secondly, in the basis of the division of procedural evidences into direct and indirect is not the 
relation of contradictory statements, as in logic, but the relation of proof (argument) to the desired position (thesis). Thus, the difference between direct and indirect evidences is in the ability of the argument to directly and independently establish a main or partial thesis. In such way, from the logical side, in criminal procedure direct evidence is an argument, which directly substantiates a main thesis. A content of such argument completely covers the thesis and directly substantiates its truth or falsity without partial theses. Accordingly, an argument, by which a partial thesis is directly substantiated that further is an argument of a main thesis, is called indirect evidence in criminal procedure.

Process of proof using indirect evidence is much more difficult and longer because it is a set of consequently built elementary acts of proof, and it is carried out, at least, in two stages. In the first stage, using true arguments partial thesis is being substantiated; in the second, a main thesis is being substantiated, and proven partial thesis is used as argument or one of the arguments of a main thesis. For example, testimony of a witness that a suspect left a scene in hurry will be an argument, which proves the fact of a suspect presence at a crime scene, that is, partial thesis. At the same time, proven fact of such presence will be one of the arguments of substantiation of the main thesis - committing a crime by a suspect.

Most scholars-processualists equate the main thesis with the so-called "principal fact" - a set of circumstances, the proof of which determine the fate of the criminal case and determines the adoption of two possible decisions in the case. A partial thesis is equated with interim fact, proof of which is not an ultimate goal, but its determination is a necessary condition for achieving such goal.

In the light of the foregoing, it can be stated that the characteristic features of procedural indirect evidence are following:

1) They are simultaneously direct and indirect evidence (arguments); regarding the interim fact (partial thesis) such evidences are direct, regarding the principal fact (main thesis) - indirect, because prove it in a roundabout way using intermediate link - partial thesis.

2) None of the indirect evidence (arguments) taken in isolation cannot independently confirm the main thesis, and the conclusion about the connection of a separate indirect evidence with the principal fact is always probabilistic.

In logic, categories of probability and reliability are used to determine the degree of substantiation of a certain thought, forms of logical thinking or system of knowledge. As noted in the scientific literature, "a statement, grounds of which can be used for other, including the statement opposite to the first, should be considered probable. On the contrary, a statement that precludes the possibility to build an opposite statement on the same grounds and, thus, refutes the first one can be considered reliable. In other words, reliability is a complete substantiation of knowledge, its complete proof' [14]. 
Therefore, when evaluating specific indirect evidence, possibility of gained knowledge indicates the possibility of another explanation of the connection between the interim fact and the principle fact and, accordingly, such conclusion has alternative nature. Reliability of knowledge, which verifies needed connection between the interim and principal facts, is provided by building reliable, consistent evidence system in a criminal case. Only together with other evidence indirect evidence can prove the main thesis.

Logical substantiation of the main thesis through indirect evidences is carried out in form of reasoning, which, closely interwoven with each other, form a chain of such deductions. Without contrasting deduction and evidence, it is worth noting that the main difference is deduction is logical form of thinking, in which new, previously unknown knowledge is being gained, in evidence, known knowledge is being substantiated, truth of which is assumed. Logic divides inferences into deductive and inductive. Deductive is inference, in course of which there is transition from the general to the particular. In this sense, the deductive inference is opposed to inductive, wherein logical transition is from knowledge about specific subjects and phenomena to general knowledge about certain range, set of researched objects.

Both deductive and inductive inferences are used in the process of proof of circumstances of criminal act. In this mentioned means of demonstration are in an inseparable unity and used for substantiation of both partial and main theses. At an early stage, when there is accumulation and statement of certain evidentiary facts (arguments) and their connection with interim fact (partial thesis) is being established, it is more common to use deductive inferences, in which there is connections of implication between prerequisites and conclusions. However, general inductive inferences are big reference to deductive inference, that is, statement, which is one of the arguments of logical proof. At the next stage, a subject of proof temporarily abstracts from the arguments of a partial thesis, and the inductive way of demonstration comes to the fore. Then again it should be noted that induction in this case is not in its pure form and statements, which are references of deduction, are conclusions of deductive inferences.

In the scientific literature on logical proof, it is stressed that in the process of "indirect knowledge law and rules of logic must be strictly enforced, because without this it is impossible to get true result consistently and on a reasonable basis" [15]. The above fully covers the process of proof of circumstances of offence with the use of indirect evidence. Compliance with logic's canons when using indirect evidence contributes to correct building of logical proof and protects it from logical errors. The most common among them are the error in thesis that is being proven; the error of false or unproven grounds; the error of too hasty conclusion; the error of equating an accidental feature with an essential feature.

The error the in thesis that is being proven is spread in logical proof. Its essence is he thesis, which is being substantiated in proof, accidentally or on purpose is replaced by other thesis. Logical fallacy of such actions is in violation of the law of 
sameness, according to which different statements-theses are equated. In the process of proof by indirect evidences the error of thesis replacement may be when the main and the partial theses are being equated. Thus, fact of detecting fingerprints of a suspect at a crime scene, indicating his presence (partial thesis), can be erroneously equated with fact of crime commission by this suspect (main thesis); fact of detecting crime instrument in a person's dwelling, which indicates only the location of such an instrument (partial thesis), is identified with the fact of committing a crime by this person (main thesis). Therefore, the error of the replacement of thesis that is being proven most often occurs where there is prejudgment. This prejudgment contributes to the equating of different theses and weakens the attention to the differences between these theses [10].

The error of false or unproven grounds can take place in proving by both direct and indirect evidence. The essence of such an error is that when proving a certain thesis, false arguments are used. Fallacy may be in wrongness of factual data (for example, knowingly wrong testimony of a witness, as if he saw that the suspect was at a scene of crime), and in absence of proof of factual data (for example, fact about traces of a suspect at a crime scene has not been confirmed by an expert).

The error of equating an accidental feature with an essential feature is also one of the widespread logical errors in the process of proof with the help of indirect evidences. Its essence is in equating accidental and regular connections, which exist between interim and main facts. For instance, fact of detection of certain thing, which belongs to a victim, in an apartment of a suspect (interim fact) may erroneously be equated with a fact of committing a crime by a suspect. However, these facts may be related occasionally, that is, a thing could be presented to a suspect, he could buy it, find it, and so on. The specified error is closely linked to the error of the false conclusion about a cause, when a simple sequence of events in time is equated with a needed causal link between these events. Thus, a fact of hasty escape from a crime scene by a person immediately after crime has been committed a may be mistakenly perceived as a fact of involvement of this person in a criminal act. However, coincidence in time does not always mean causal link of events: a person might escape from a scene because of reluctance to communicate with law enforcement officers, fright, etc.

In the process of proof, there are also other logical errors: of false consequence, of increase of terms, of a transition from what was said in a certain sense to what was said irrelevantly, etc. All of them can take place in proof of circumstances of a committed crime using indirect evidence. That is why their recognising and overcoming, based on the laws and rules of formal logic, ensures not only the correct building of logically clear proofs, but also helps to avoid legal errors in investigative and judicial practice.

\section{CONCLUSIONS}

Determining of the nature of indirect evidence in criminal procedure should be based on the logic of the notion of evidence. In this, should be taken in account: 
1. The logical notion of indirect evidence does not coincide with the content of the notion of indirect evidence in the science of criminal procedure. Such discrepancy is due, at least, two factors: 1) in criminal procedure evidence is not a process of selection or search for grounds in favour of a certain thesis, but a means to achieve the ultimate goal of such, that is, argument of logical evidence; 2) in the basis of the division of procedural evidence into direct and indirect is the ability of the argument to directly and independently establish a main or partial thesis, but not the relations of contradictory statements, as in logic.

2. On the logical side, the indirect evidence in criminal procedure is the argument of a partial thesis, which further is the argument of a main thesis. This explains dual essence of procedural indirect evidences: they are direct evidences and independent means to prove its truth of fallacy regarding partial thesis; indirect evidences, which only together with other can prove its truth or fallacy regarding main or generalising thesis.

3. Proof of existence (inexistence) of facts and circumstances that took place in the past is in form of inference. Building of inference does not preclude a possibility of logical errors which also take part in proof of circumstance of committed crime using indirect evidences.

\section{REFERENCES}

[1] Muñoz-García, M. Á. (2016). The indirect violation of the substantial law by factual errors in criminal cassation. Vniversitas, 65(133), 139-190.

[2] Rappaport, J. (2018). Criminal justice. Columbia Law Review, 118(8), 2251-2322.

[3] Spencer, D. (2018). Overview of Language Rights in the International Criminal Law Sentencing Models. International Journal for the Semiotics of Law, 31(4), 787-804.

[4] Binnall, J. M. (2018). Summonsing Criminal Desistance: Convicted Felons' Perspectives on Jury Service. Law and Social Inquiry, 43(1), 4-27

[5] Roux, C., Ribaux, O., \& Crispino, F. (2018). Forensic science 2020-the end of the crossroads? Australian Journal of Forensic Sciences, 50(6), 607-618.

[6] Bystritskiy, E. K., Bulatov, M. O., \& Ishmuratov, I. T. (2002). Philosophical encyclopedia dictionary. Kiev: H. S. Skovoroda Institute of Philosophy.

[7] Kondakov, M. I. (1975). Logical reference-dictionary. Moscow: Nauka.

[8] Asmus, V. F. (1967). Proof and refutation. Moscow: Gospolitizdat.

[9] Prohorov, Yu.B. (2004). Proof in criminal process (epistemological and law interpretation). Sankt-Petersburg: Izdatelstvo.

[10] Asmus, V. F. (1954). Doctrine about proof and refutation. Moscow: Gospolitizdat.

[11] Kirillov, V. I., \& Starchenko, A. A. (1995). Logic. Moscow: Yurist.

[12] Torful, M. G. (2006). Logic. Kyiv: Akademiya.

[13] Eisman, A. A. (1964). About some logical systems of connection of indirect evidences. Issues of Criminalistics, 12, 50-69.

[14] Luzgin, I. M. (1969). Investigation as cognitive development. Moscow: Nauchno-issledovatelskiy i redaktsionno-izdatelskiy otdel.

[15] Starchenko, A. A. (1958). Logic in court proof. Moscow: Gosyurizdat. 


\section{Oksana K. Tugarova}

Candidate of Juridical Sciences, Associate Professor

Department of Organization of Protection the Restricted Access Information Educational and Scientific Institute of

Information Security of National Academy of the Security Service of Ukraine 03022, 22 M. Maksimovich Str., Kiev, Ukraine

Suggested Citation: Tugarova, O. K. (2019). The logical nature of indirect evidence in criminal procedure. Journal of the National Academy of Legal Sciences of Ukraine, 26 (1), 141-152.

Submitted: 21/01/2019

Revised: 19/03/2019

Accepted: 28/03/2019 
УДК 343.14

DOI: 10.31359/1993-0909-2019-26-1-153

Олександр Миколайович Толочко

Національна академія прокуратури Київ, Україна

\title{
СТАНДАРТИ ДОКАЗУВАННЯ У КРИМІНАЛЬНОМУ ПРОВАДЖЕННІ (ПОРІВНЯЛЬНИЙ АНАЛІЗ)
}

\begin{abstract}
Анотація. Нова парадигма пізнання, яка властива змагальним процесуальним системам закріплена в новому КПК і вимагає змін в технологї доказування та встановленні істини у кримінальному провадженні. Результати судових кримінальних проваджень свідчать, щзо судді при визначенні належності, допустимості та достовірності доказової інформаиії, застосовують положення сучасних доктрин доказування. У кримінальному процесі основним завданням досягнення результату є формування обвинувального вироку на основі винесеного судового рішення. Кожне рішення при изьому трунтується на незалежній оцінці представлених доказів. Саме иче формує актуальність проведеного дослідження: пошук методологічних і формувальних прийомів оцінки представлених доказів. Автор зазначає, щзо докази мають різну природу походження $i$ застосування. Отже, є необхідність у застосуванні доказів, в рамках судового процесу. Авторами статті представлена детальна методологія на основі розробок процедури доведення. Встановлено, щзо застосування стандартів дозволяє використовувати в рамках кримінального процесу диференційовані джерела, тим самим визначаючи кордон взаємодії суб'єктів кримінального прочесу. Авторами статті визначено принципи, які формують відкриті стандарти доведення, тобто застосування яких можливо усіма зацікавленими сторонами і які неможливо перевірити з боку контролюючих та наглядових органів. Авторами в статті наводиться не тільки основа для розробки методологічного критерію, але також і визначається його практичне застосування у всіх можливих інтерпретаціях. Практичне значення одержаних результатів визначається иуіляи підвищення прозорості кримінального процесу, а також можливостями залучення до очінки представлених доказів $і$ загального процесу доказування профільних експертів. Наведені приклади судових рішень є свідченням того, щуо припис чинного законодавства України КПК Украӥни в частині недопустимості фактичних даних, здобутих завдяки інформації, отриманій внаслідок істотного порушення прав і свобод людини, застосовується судами Украӥни, як правило, без винятків.
\end{abstract}

Ключові слова: процес доказування, стандарти, кримінальне судочинство, об'єктивність, розгляд.

Oleksandr M. Tolochko

National Prosecution Academy of Ukraine Kyiv, Ukraine

\section{STADARDS OF PROOF IN CRIMINAL PROCEDURE (COMPARATIVE ANALYSIS)}

Abstract. In criminal process the main task of achieving result is forming of a verdict of guilty
or acquittal on the basis of court decision. In this, every decision is grounded on independent
evaluation of given evidences. Exactly these form the actuality of research - search for metho- 
dological and forming methods of evaluation of evidences. The author points out that evidences have different origin and application. That is why there is necessity that use of evidence in the framework of a judicial process has unified methodology. The author of the article provides such methodology on the basis of development of proof procedure. It has been determined that application of standards allows to use within criminal process differentiated sources thereby defining the boundaries of interaction between the subjects of the criminal process. The author of the article has found principles that form open standards of proof, that is, application of which is possible for all interested parties and which can be verified by controlling and supervisory bodies. The author in article provides not only the basis for development of methodological criteria, but also defines its practical application in all possible interpretations. Practical significance of research is defined by goals to increase transparency of criminal process and the possibilities of engaging relevant experts in the evaluation of evidence and general process of proof.

Keywords: process of proof, standards, criminal proceeding, objectivity, hearing.

\section{INTRODUCTION}

After renovation of criminal procedure legislation, law enforcement practice remained without strong scientific support in the field of evidence in criminal procedure [1]. The reason is certain attempts to stay in the paradigm of previous formally dogmatic doctrines including procedure proof [2]. The normativist way of thinking of a certain number of proceduralists is conditioned by the absolutist outlook of domestic jurisprudence, whose philosophical basis is dialectical materialism. New cognitive approaches to philosophical problems of evidence are perceived negatively that does not allow domestic scientists to refuse a number of concepts of inquisitorial-investigative ideology of pre-trial proceedings, which is inherent in the idea that study of evidence in court is a continuation of pre-trial investigation [3]. Accordingly, there is no significant procedural difference between trial and pre-trial evidence. That is why validity of protocols of investigation is presumed and is almost not questioned in trial [4].

However, according to the renewed national criminal procedure law a contradiction between a written secret investigative legal form of establishing evidence and a new legal ideology, which is based on priority of rights and freedoms of human embodied in the system of procedural means (presumptions), objectively grows. The investigator turned into a party of charge. Since a defence is limited in possibilities for gathering evidence and the main way to gather is investigation, which is carried out by a party of charge, in trial there are doubts about objectivity and impartiality of an investigator (presumption of the accusatory matter) [5]. According to judicial procedure a defence cannot and must not recognise as reliable information, which is collected by opponents of an accused. In addition, while maintaining the existing model of proof, the result of which is fixed in the written documents, in evaluating the evidence, the emphasis on the formal element (evaluation of details of procedural documents) will be strengthened. Completion of parties in court will turn in discussion about admissibility of evidence and lower priority will be given to their affiliation, validity and sufficiency. 


\section{MATERIALS AND METHODS}

The basis of the study is the method of comparative law. It applies for purposes of comparison of certain provisions of criminal procedural legislation. In particular, the basis to apply standards of proof is being disclosed. The structure of a legislative act for the purpose of integrating the methodological framework into the proof process is being determined.

Historical method defines the sources of appearance and application of evidence in general structure of criminal process. This method is used to correlate the application of proof standards to the evidence itself, which, in their turn, have been obtained applying certain standards of obtaining.

Method of modelling a legal decision is used not only as recommendation method, which allow expanding application of related complex standards of proof in the process of forming a court decision, but also let implement accompanying proof processes to correlate them with leading methods and techniques of proof procedure.

Method of analysis revealed that in countries if continental law the traditional approach is approach, according to which finding truth the purpose of court. Thus, the saying of K. I. Malyshev that truth is equally necessary for the trial as justice has truly become catching. Though, in practice finding truth is not that simple, it is exactly truth has being keep stated as a purpose of trial. In fairness, it is worth noting that recently truth is perceived as pious wish without reference to specific means of its search and without answers to question what king of truth is established in the process.

Standards of proof, on the contrary, sometimes are considered far from truth. In many ways, this perception is associated with the name of one of them - "balance of probabilities". Probability is far from truth. Moreover, even criminal procedure standard "out of reasonable doubts" in the classical saying of Lord Denning is defined through a degree of probability. I. V. Reshetnikova also points out that standards of proof do not follow the goal to find truth. However, actually everything is different. Firstly, even Soviet doctrine allowed establishing knowledge based not on truth, but on probability. Thus, S. V. Kurylev notes that in the field of court proceeding jurisdiction of probability is wider. As an example he cites cases of fact establishment basing on presumptions or in the situation when there is no sufficient evidences of presence or absence of fact, which court is obliged to establish. A. T. Bonner also writes about probability. Secondly, standard of balance of probabilities is not boiled down only to the fact that position of one side is more probable than position of other. The probability of proving even should be possible and based on common sense.

\section{RESULTS AND DISCUSSION}

Reconsideration of views on the role of judicial bodies in system of managing public processes is conditioned by division of state power into legislative, executive and judicial [6]. Reorganisation of state power necessitated a scientific understanding of the concept of judicial power, functions and forms of its implementation and natu- 
rally has led to recognition of judicial power as a main power providing rights and freedoms of human and citizen. Judicial protection of interests slowly, but consistently comes to the fore in the system of state guarantees of human rights and freedoms. In connection with this, reconsideration of the court role in criminal process in unavoidable: court becomes independent subject of special powers able to objectively and fairly hear and resolve a criminal case that is actuality of this research. The author demonstrates that new forming legal reality requires abandonment of dogmatic notions about main criminal procedure institutions hindering their effective implementation [7]. Research of many problems of criminal court proceeding appearing under new social and legal terms from the perspective of modern scientific views on judicial power and value of human personality, is one of the actual tasks of modern science. The most important among such problems are issues of organisation of proof process. It is noted that participants of proof process implement rights and duties provided by criminal procedure law; criminal procedure guarantees completely cover them. In proof process use of procedure forcing is also unavoidable. In connection with mentioned, evidence law also include norms by structure located in other sections of the Code of Criminal Procedure, but regulating the process of proving.

New paradigm of knowledge, which is inherent to competitive procedure systems, is fixed in the new CPC and requires changes in technology of proof and establishing truth in criminal procedure [2]. Results of court criminal procedure demonstrate that judges determining affiliation, validity and sufficiency of proof information use provisions of modern doctrines of proof. That is why it can be stated that domestic procedure science has fallen behind in the development of such concepts as cross-questioning technique, art of formulation and articulation of questions, admissibility of leading questions, lingual-psychological power of court evidence, proof of guilty beyond reasonable, interpretation of al doubts concerning proof of guilt of an individual in his/her favour, etc. [6].

Speaking of proof standards two are usually mentioned: valid in civil process balance of probabilities or, as it is called in the USA "preponderance of the evidence", and standard beyond reasonable doubt, which is valid in criminal court procedure. However, actually there are three standards of proof [8]. Yet only American lawyers accept it. In practice there may be other standards of proof (for example, comfortable satisfaction). However, all of them are no more than results of combination of three mentioned above.

The third standard of proof is standard of clear and convincing evidence. In literature there is position that it has not worked out in jurisprudence of England. Instead of this, English courts speak about a higher degree of probability. Initially, American judges used different words to indicate requirements to provide higher degree of prov- 
ing: "clear, sufficient and convincing evidence", "clear, overwhelming and convincing evidence", "explicit and obvious evidence", etc. The saying "clear and convincing evidence" also has worked out.

In the current instruction to the jury in civil cases of the California, it is noted that clear and convincing evidence are required in cases where the most important individual rights and interests such as termination of parental rights, involuntary gospitalisation, deportation, are at stake. It also notes that the mere weight of the imposition of a private law sanction does not entail the application of a more stringent standard of proof. Such approached may be noticed also in practice of the Supreme Court of the USA.

Mentioned in instruction categories is not an accidental set of discussions. Necessity to prove basing on clear and convincing evidence in cases of such type is established by the Supreme Court of the USA. The necessity of a higher proof standard in American courts is explained by constitutional requirement of adequate legal protection. As it may be understood, such standard is aimed at alignment of procedural inequality and protection of personal interests when they confront public interest.

In this, it should be remembered that standard of clear and convincing evidence (as well as other standards) may be directly mentioned in law or follow from it. For example, exactly this standard of proof, in the opinion of the Supreme Court of the USA, is proper in cases of invalidating patents. Most judges of the SC of the USA emphasised that application of the standard of clear and convincing proofs followed out of law.

Nevertheless, application of stricter proof standard may be based on other reasons too. For example, standard of clear and convincing evidence is applied in imposing punitive damages. The fact is that such damages are considered as "punishment", i.e. aimed at achieving the goals that are inherent in criminal law. Although in such matters only monetary amounts are at stake, their value is quite substantial.

We also note that, despite the fact that the phrase "beyond reasonable doubt" has become familiar, it is not always used in modern literature and practice.

In foreign literature it is admitted that the phrase "beyond reasonable doubt" is fraught with confusion, especially, if try to explain it through the difference between terms "sure" and "certainty".

In particular, the jury of the case R. v. Majid (2009) faced this difficulty. That is why now such standard is described as proof, which makes the jury sure. In such way, it is considered that prosecution manages to prove own rightness, if the jury after considering all evidence are sure that an accused is guilty.

The decision in case Rhesa Shipping Co. SA v. Edmonds (1985) was boiled down to this. That is why in case when "probabilities" (positions of a claimant and respondent) are equal, respondent wins. In such case it is stated that a claimant did not fulfil his/her burden of proof [9]. 
Is there criterion of sufficiency in Russian court proceeding? It is obvious that the answer should be positive, because courts by virtue of direct indication of law evaluate also sufficiency of evidence. Evidences are evaluated by inner conviction, so the state of inner conviction itself can be a measure of sufficiency. A criterion seems to be quite subjective. However, considering the ideas of achieving truth, exactly truth can be called a criterion of sufficiency. Consequently, parties have to provide such sets of evidence proving its position, which allow to make all circumstances obvious, consistent, and knowledge of them can be considered true, in the framework of a competitive process with participation of private persons negative side of this criterion is quite obvious: parties have too heavy burden of proof.

Against the background of the Russian criterion of sufficiency, proofs standards appear to be very attractive and even objective criteria. But is it so?

To start, we focus on that the standard "beyond reasonable doubts" or the standard "certainty of guilt" is also very subjective, because certainty (as conviction) - is internal state that is difficult to manage. The standard of clear and convincing evidences is no less subjective.

It seems that the balance of probabilities is intuitively simpler and more understandable, because implies a simple advantage in favour of one of the parties. In addition, such standard is perceived as subjective: it is about a probability, which is measurable. Often this standard is described through numerical expression "if a claimant fulfilled a burden of proof and could convince a judge in his/her rightness, then he won with a probability of at least 51 against 49". However, numerical expression of this phrase is notional and has a descriptive purpose.

When making decision a judge (or jury) does not conduct mathematical calculation of probability [10]. Strict criteria of standards have not developed, as V. K. Puchinskiy underlined. Apparently, the situation has not changed and for now. In west literature reviewers note that it is impossible to formulate the exact meaning of civil and criminal proof standard.

In addition, in practice of English courts, the balance of probabilities is understood not so unequivocally and simply. A number of guiding principles in application of this standard is laid down in two decisions of the House of Lords: Re H (minors) (Sexual Abuse: Standard of Proof) and SoS for the Home Department v. Rehman. In particular, one of them is about flexibility of application of the balance of probability.

The flexibility of the standard is based on the fact that some events are more likely than others.

Thus, it is considered that a person committed negligence rather than misled, caused damage by chance rather than deliberately caused harm. To describe probability the words of Lord Hoffman, said in the decision on the second case, became common: "To satisfy one that the creature seen walking in Regents Park in London was more likely than not to have been a lioness than to be satisfied to the same standard that it was a German Shepherd dog". 
Unlike American courts in English literature it is pointed out that there are no intermediate standards. Instead of this the practice suggests various fillings of the standard of the balance of probability. The more serious statements or its consequences, the more powerful evidences should be provided to court in order to prove this statement on the basis of the balance of probability. The flexibility is not in the probability, but in the power or quality of provided proof. Probability or improbability of an event themselves become a question, which should be taken into account when weighing the probability and deciding whether this event really has been.

The origins of the problem of flexibility of the proof standard are probably laid in the case of Bater v. Bater (1951).

The case was about the divorce, but lord Denning expressed general judgments concerning proof and other civil cases. In particular, he noted that in the standard of the balance of probability the probability could have different degrees, which depended on a subject of dispute [11]. For example, when hearing the case about fraud, lord Denning considered to be natural to require higher degree of certainty than in the case about negligence. Nevertheless, such strict standard should be weaker than a legal criminal. However, further judges refused the existence of the intermediate (third) standard, having decided that it is more correct to speak about power and persuasiveness of proof.

Perhaps, this approach carries some uncertainties and intellectually such constructions are difficult to perceive. In addition it seems obvious that power and weight of proof directly affect a degree of certainty. Maybe continental approach to the evaluation of proof bothers to descry details? It is doubtful. Thus, the authors of the famous textbook "Murphy on Evidence" describing the standard of proof say that this is measurement of quality and persuasiveness of proof. Admitting that the probability remains the same, only requirements to proof change, English lawyers probably allow a certain degree of slyness. Under this approach difference between proof standard may be illusory.

In this, flexible is not only the standard of the balance of probability, but also the solution of question about what proof standard to apply. That is why in formally civil cases whether even the balance of probability cannot be applied or higher proof standard may be established. In practice, the latter, for clarity, is usually called the criminal standard.

For a long time divorce processes have been resolved on the basis of criminal standard. However, modern practice has chosen the way of applying the standard of the balance of probability. The analogical standard is applied in the situation when a person has been charged with criminal offence. For example, act of fraud, in particular fraudulent representation when conducting a bargain (Hornal v. Neuberger Products Ltd.). Afterwards other judges referred to this decision justifying the flexibility of the civil proof standard. Also, there is number of specific situations-exceptions to the general rule about the proof standard in the civil process. 
Among modern domestic scientific conceptions, which represents theory of criminal procedure proof, approach suggested by the scientists V. P. Gmyrko is worth of special attention. The scientific character of his approach is in overcoming the "gap" between "activity positioning of evidence and inactivity practice of his theoretical mastering (comprehension)". The practical value is consistent comprehension and application of procedural rules (standards) of proof in criminal procedure.

Domestic theory of proof should consider reasonable balance of development of the criminal process in two classical models: a) Due Process Model, which proclaims the main priority the protection of individual rights and freedoms, the provision of which is ensured by providing the maximum guarantees of their implementation to persons who have fallen into the criminal-procedural sphere; b) Crime Control Model, the basis of which is the protection of society and its member (potential or real victims) from offences; this basis allows a significant restriction of individual rights and freedoms for achieving maximal effectiveness (G. Parker).

In connection with this national criminal procedure, system should always pay attention to the improvement of the system of evidence law in order to be consistent and able to respond to changes in social conditions and needs. The measure of such improvement is international standards (rules) and proof doctrines in criminal procedure. Among international proof standards there are proof rules, which are content elements of the presumption of innocence ("the right against self-incrimination", "right of an accused to remain silent", "proof beyond a reasonable doubt", interpretation of reasonable doubt in dubio pro reo").

The component of proof methodology is the provision concerning "proof of guilty beyond a reasonable doubt". If this standard is not complied with, the fact cannot be regarded as established and be the basis of the indictment [12]. In the Ukrainian legal system this proof standard is new unlike English and American systems wherein it has existed for a long time. The burden of proof of all the circumstances of the case and the conviction of the jury in the defendant's guilt beyond a reasonable doubt lies entirely on the prosecution side. Such proof according to the legal position of European Court states the absence of irrefutable, weighty, clear, consistent with each other presumptions and signs of guilt (the decision in cases "Kobez v. Ukraine", "Avsar v. Turkey"). The modern vision of "a reasonable doubt" may be boiled down to two components: 1)proof beyond a reasonable doubt does not mean proof beyond all possible doubts; 2) proof beyond a reasonable doubt is defined as such a convincing proof because of which a person can act without hesitation. Its essential features are, firstly, certainty, steadfastness, absence of any hesitations; secondly, it is not equal to the definition "absolute certainty" [13].

The provision concerning proof of guilty beyond a reasonable doubt is a general ground not only for a judge, but also for parties of criminal procedure, that is why it changes not only approaches to the evidence evaluation, but also affect a model of 
competition in criminal procedure. The purpose of defence can be defined as both in the sense of "to prove the reverse" and in the sense of "refuting the allegations as doubtful" (the decision in the case "Allan v. the United Kingdom"); public recognition of a person's innocence until a person will be convicted by a competent court; obligation of officials to refrain from revealing statements and assessments; impossibility for a state to use non-criminal procedures to obtain recognition of guilt in committing a crime and/or imposition of sanctions equal to a criminal penalty; the inadmissibility of the accusatory matter in the work of judges [12].

In practice of European court, human rights have been used to formulate "reasonable suspicion" as proof standard, as the standard for evaluation the validity of a prosecution when choosing a preventive measure, under which there is facts that indicate commitment of criminal offence by a person and also risks, which give reasonable grounds to believe that a suspect will impede criminal proceedings or commit criminal offences. Besides, inadmissible methods of gathering evidence, which violate rights and freedoms of a person: 1) questioning the suspect as a witness ("Lutsenko v. Ukraine"); 2) right of a person not to testify against relatives and spouses ("Asch v. Austria" "Unterpertinger v. Austria"); 3) absolute inadmissibility of evidence obtained through torture or ill-treatment at their threat ("Gafgen v. Germany", "Harutynyan v. Armenia", "Gogmen v. Turkey"); 4) inadmissibility of evidence obtained under pressure from the accused or evidence obtained with a material violation of the right of a person to privacy, housing, correspondence, telephone conversations ("Magee v. the United Kingdom”, "Jalloh v. Germany").

Updated doctrinal approaches to the rules of admissibility of evidence. The doctrine of asymmetry of the rules of admissibility of evidence establishes: 1) prosecutorial or other evidence, which worsen a position of a suspect, accused, obtained in violation of the criminal procedural law, in any way should be inadmissible; 2) illegally obtained exculpatory evidence, which commute sentence should be taken into consideration by the court at the petition of the party concerned. In Ukraine this theory has not gained its legislative consolidation and practical application.

The CPC of Ukraine recognises inadmissible evidences obtained due to information received as a result of a significant violation of human rights and freedoms (P.1 of Art. 87) [14]. That is why the doctrine of "fruit of the poisonous tree" has been mainstreamed; it claims that evidence obtained due to the violation of the constitutional rights of persons loses its legal force (originated in US case law in the early 20th century). In American criminal procedure evidence can be brought before a court during trial if it has evidentiary weight to prove a certain fact (act. 402 of the USA Federal Rules of Evidence). Inappropriate evidence is inadmissible. They also may be inadmissible in the cases: 1) if their admission leads to an unjust prejudice or misleading jury; 2) unjustified delay, excessive use of court time or unnecessary representation of a large amount of evidence collected together; 3) if these are hearsay; 4) when they are obtained 
in violation of procedure or obtained in violation of benefits or witness' immunity; 5) their recognition in court as unexpected for one party if they are filed by the other party after the completion of the pre-trial hearing. The Supreme Court of the USA does not rule out the examination of evidence if they were obtained illegally, but would still have been prosecuted, with greater effort ("Nix vs. Williams") or evidence obtained through unintentional police mistakes ("The United States v. Leon").

The doctrine of "fruit of the poisonous tree" is not characteristic for continental type of criminal process $[15 ; 16]$. In particular, the CPC of the Federal Republic of Germany does not imply normative determination of admissibility (inadmissibility) of evidence, but the issue of their proper evaluation is settled, therefore, the evidence obtained as a result of illegally obtained information is evaluated as admissible. The exceptions are the prohibition to use testimonies obtained through physical influence, drugs, torture, hypnosis, etc.; violation of which automatically entails their inadmissibility (art. 136sa of the CPC) [14].

French system of proof is based on free proof evaluation by inner conviction of an investigative judge, prosecutor, judge, court. Any evidence is admissible regardless of whether it is indicated in law or not, but in the process of proof or conducting investigative actions, it is forbidden to violate the procedural law and to preserve decency, that is, to use means that are in accordance with the fundamental principles of the rule of law (art. 427 of the CPC).

The doctrine of "fruit of the poisonous tree" is being used in practice of European Court with its corresponding development. In solving the problem of evidence derived from an illegal, the Court estimates, how much an illegality of the initial investigative action poisons following evidence. If sentence was completely based on materials investigated in a court session, and none of the protocols of pre-trial investigation was taken into account, the right to a fair trial was not violated ("Allan vs. The United Kingdom", "Gafgen v. Germany"). However, the Court find inadmissible evidence obtained as a result of illegally obtained information with significant violations of the right of a person to legal assistance based on the traditional approach of "fairness of the process as a whole" (Todorova v. Ukraine).

Domestic court practice demonstrates that quite often the component of grounding of acquittal sentences, which constitute the content of the doctrine of "fruit of the poisonous tree ". In particular, court finds inadmissible evidence an expert's conclusion that the subjects submitted to the investigation received as a result of an illegal search, since the decision of the investigating judge did not contain circumstances with reference to evidence and other materials, with which prosecutor substantiated the petition for the search, and in the resolution part of the decree did not indicate the objects to be searched (the case № 136/940/14-k. dated December 27, 2014). In the other case the court upheld the verdict of acquittal because it considered the expert's opinion to be inadmissible since the evidence filed for an expert study was removed during an illegal 
review of the place of the event without the participation of the witnesses, although incorrect information regarding their participation had been recorded (the case № 490/12158/13-k dated May 5, 2014).

\section{CONCLUSIONS}

Mentioned examples of court decisions demonstrate that order of p. 1 of art. 87 of the $\mathrm{CPC}$ of Ukraine regarding the inadmissibility of factual data through information obtained as a result of a significant violation of human rights and freedoms, is used, as a rule, without exceptions. However, as it was showed above, this doctrine is not absolute even in the country of its origin and the practice of the European Court. That is why, in every specific example of court's evaluation of the admissibility of any evidence the significance of the alleged violations of the criminal procedural law and the importance of each evidence for establishing the circumstances of the criminal proceedings should be taken in account.

Rights of defence and prosecution in out ore-trial proceeding are not equal. Prosecution, which carries all difficulties due to the duty of proof, should also have such powers that allow effectively fulfill the duty. Defence as represented by an accused and defence counsel has fewer powers, but it is also relieved from the duty of proof. In such way, inequality of parties' rights in pre-trial proceeding compensates with unequal division of duties. It could be said that an accused is protected not by his/her rights, but by duties assigned on subjects of criminal prosecution.

Real competition of parties in full extend is possible only in judicial proceeding where there is an arbitrator independent of the parties who, by direct instruction, is not a body of criminal prosecution. Independent court makes decision exclusively by inner conviction, by law and conscience. Because the basis for inner conviction is totality of evidence of case, independence of court from preliminary conclusions of bodies of criminal prosecution and, consequently, from their preliminary evaluation of evidence, is provided by examination of all evidence in court prosecution in the presence and with the participation of both parties. Independence of court is provided also by equality of parties' rights in court prosecution, which is aimed at neutralisation of benefits of prosecution conditioned by its rights at the stage of preliminary investigation.

At the same time, only independent judicial power is able to ensure true competitiveness of parties, i.e. to treat equally unbiased the arguments presented by the parties in support of their positions, to create really equal conditions for them including mechanism of compensation of their factual and processual inequality in pre-trial prosecution. Independence of court, as we may see, is a guarantee of competitiveness of all criminal proceeding.

In such way, competitiveness is a form of administration of justice in country where independent judicial power functions. One follows from the other and is provided by them. Recognising the independence of judiciary in practice, we are obliged to recognise and really ensure its competitive principles. 


\section{REFERENCES}

[1] Korol, V. V., \& Sadova, T. V. (2013). Indications as a source of evidence in criminal proceedings. Scientific Herald of Dnipropetrovsk State University of Internal Affairs, 3, 428-434.

[2] Bandurka, O. M., Blajivskiy, E. M., \& Burdol, E. P. (2012). Criminal procedural code of Ukraine. Kharkiv: Pravo.

[3] Stahivskiy, S. M. (1994). Investigative actions as the main means of gathering evidence. Kyiv: Atika.

[4] On Forensic Examination: Law of Ukraine (1994, February). Retrieved from http:// zakon.rada.gov.ua/laws/show/4038-12.

[5] Decision of the Constitutional Court of Ukraine in the case of the constitutional petition of the Security Service of Ukraine regarding the official interpretation of the provisions of Article 62.3 of the Constitution of Ukraine (2011, October). Retrieved from http:// zakon.rada.gov.ua/laws/show/v012p710-11.

[6] Grosheviy, Yu.M., Tatsiy, V. Ya., \& Tumanyats, A. R. (2013). Criminal process. Kharkiv: Pravo.

[7] Criminal procedure code of Ukraine: the law of Ukraine. (2012, April). Retrieved from http://zakon.rada.gov.ua/laws/show/4651-17.

[8] Pogoretskiy, M. A. (2007). Functional appointment of operational and investigative activities in the criminal process. Kharkiv: Arsis LTD.

[9] About realisation of certain provisions of the Criminal procedure Code of Ukraine: the resolution of the Cabinet of Ministers of Ukraine. (2012, November). Retrieved from http://zakon.rada.gov.ua/laws/show/1104-2012-п.

[10] Rogatynska, N. (2016). Some features of conducting an investigative experiment in criminal proceedings. Actual Problems of Law, 2, 152-154.

[11] Sychuk, M. (2011). Legal grounds for the adoption of procedural decisions on the conduct of investigative actions. Entrepreneurship, Economy and Law, 10, 153-158.

[12] Tutunnyk, V. V. (2014). The obvious inadmissibility of evidence as a criterion for the implementation of a separate judicial procedure for the recognition of evidence is inadmissible in criminal proceedings. Scientific Herald of Uzhgorod National University. Series "Law", 28 (3), 137-140.

[13] Udalova, L. (2013). Some issues of the question of enforcement of criminal procedural law. Actual questions of the criminal procedural legislation of Ukraine. Materials of InterUniversities. Sciences Conference (pp. 11-13). Kyiv, Ukraine.

[14] The criminal procedure code of Ukraine. Retrieved from https://zakon.rada.gov.ua/laws/ show/4651-17

[15] Shepitko, V. Yu. (2007). Criminalistics tactics (systematic structural analysis). Kharkiv: Yaroslav Mudriy National University.

[16] Yanovskya, O. G. (2013). Competitive principles of the process of proof in the criminal proceedings. Legal Ukraine, 8, 77-82.

\section{Oleksandr M. Tolochko}

Candidate of Juridical Sciences, Professor

State Counsel of Justice of the 3rd Class

Honored Lawyer of Ukraine 
Vice-Rector of National Prosecution Academy of Ukraine 04050, 81-b Melnikov Str., Kiev, Ukraine

Suggested Citation: Tolochko, O. M. (2019). Stadards of proof in criminal procedure (comparative analysis). Journal of the National Academy of Legal Sciences of Ukraine, 26 (1), 153-165.

Submitted: $17 / 01 / 2019$

Revised: $18 / 03 / 2019$

Accepted: 28/03/2019 


\section{- REVIEW ARTICLES •}

УДК 340

DOI: 10.31359/1993-0909-2019-26-1-166

\author{
Вільям Батлер \\ Школа права \\ Університет Пенсильванії \\ Пенсильванія, США
}

Віктор Миколайович $\boldsymbol{E}_{\text {рмолаєв }}$

Наиіональна академія правових наук України

Інститут післядипломної освіти

Національний юридичний університет імені Ярослава Мудрого

Харків, Україна

\section{НА ШЛЯХУ ДО СОБОРНОСТІ УКРАЇНИ (ДО 100-РІЧЧЯ АКТА ЗЛУКИ УНР ІЗ ЗУНР)}

Аннотація. B історії держави і права України є пам'ятні події, правові пам'ятки, значення яких повністю усвідомлюється лише з часом, особливо в нинішню добу активного державотворення. Тому у статті зроблена спроба короткого історико-правового аналізу державотворчих процесів на шляху до об'єднання украӥнського народу та його земель з початком Української революиії. Встановлено, щзо Украйнська Центральна Рада (далі - УЦР) була створена як організаџія парламентського типу. А для надання ій «характеру справжнього представництва всього організованого українського народу» було скликано багатолюдний Національний конгрес. Виявлено, щзо на даному конгресі і було визначено форму державного устрою Украӥни як національна-територіальна автономія. Конгрес, як повноважний представнищький орган, «передпарламент», уособлював вже соборну Украӥну. Так була юридично вирімена історична проблема злуки обох частин Украӥни. Трудовий конгрес висловлював рішучий протест проти замахів на цілісність, самостійність і незалежність Української Народної Республіки. Він проголошував: «Украӥнський народ хоче бути нейтральним і в дружніх відносинах з усіма іншими народами», вказував на загрозу для республіки з боку «імперіалістів і совєтської Росії». Діяльність Центральної Ради визначали політичні партії сочіалістичного спрямування: з 19 партій (українських, російських і польських), 17 називали себе соціалістичними. Акт злуки наочно показав безсилість спроб роз'єднати український народ, протиставити його різні частини в Першій світовій війні, примусити служити чужим для них иілям. Проте подальший, трагічний для України, перебіг подій і наслідки світової війни, затверджені Версальським договором 1919 р., надовго затримали фактичний процес об' єднання всіх украйнських земель. Історичний досвід застерігає: національні інтереси набагато вищі і важливімі за партійні чи корпоративні, розбудова в Украӥні правової, сочіальної, демократичної держави вимагає політичної й духовної єдності всіх громадян.

Ключові слова: Українська Народна Республіка, Українська Центральна Рада, Акт злуки. 
William Elliott Butler

School of Law

University of Pennsylvania

Philadelphia, USA

Victor M. Yermolaiev

National Academy of Legal Sciences of Ukraine Institute of Postgraduate Education

Yaroslav Mudryi National Law University

Kharkov, Ukraine

\title{
TOWARDS THE COURSE OF UKRAINE (TO THE 100TH ANNIVERSARY OF THE ACT OF UNIFICATION OF THE UPR WITH ZUNR)
}

\begin{abstract}
In the history of the state and law of Ukraine there are immemorial events, legal monuments, the significance of which is fully realized only with time, especially in modern times. Such an event and attraction is the Act of reunification of the Ukrainian People's Republic and the West Ukrainian People's Republic on January 22, 1919. This article attempts to make a short historical and legal analysis of the processes of state-building on the way to the unification of the Ukrainian people and their lands with the beginning of the Ukrainian revolution. It began after the February bourgeois-democratic revolution of 1917 in Petrograd to create in Kiev in early March, public organizations and political parties, emerged from the underground, the Ukrainian Central Rada (hereinafter - UCR). The latter was created as a "parliamentary organization". In order to provide her with the "nature of the present representation of the entire organized Ukrainian people," in April 1917 a crowded National Congress was convened. He determined the form of the state structure of Ukraine - national-territorial autonomy as part of federal democratic Russia, with the main principles of autonomy. The Congress replenished the composition of the UCR, elected its Chairman - Grushevsky. Subsequently, at its V and VI sessions, as a result of the new reorganization and replenishment of membership in territorial and party representation, as well as at the expense of elected members from military, public, trade union organizations, national minorities, the UCR already had 643 deputies. The activity of the Central Rada was determined by political parties of the socialist direction: from 19 parties (Ukrainian, Russian and Polish), 17 called themselves socialist. This led to the direction and content of the state implemented by the Ukrainian Central Rada and its government - the General Secretariat.
\end{abstract}

Keywords: Ukrainian People's Republic, Ukrainian Central Rada, Act of Reunification.

\section{INTRODUCTION}

In the history of state and law of Ukraine there are memorable events, legal monuments, the meaning of which is comprehensible only in course of time, especially in the current period of active state formation. Such event and monument is Act Zluky of the Ukrainian People's Republic with West Ukrainian People's Republic on January 22, 1919. The Presidential Decree "On Measures to Celebrate the 100th Anniversary of the Events of the Ukrainian Revolution of 1917-1921" contemplates "To 
determine the commemoration of events and prominent participants of the Ukrainian Revolution of 1917-1921 as one of the priorities of the state authorities in 20172021" [1]. The Decree mentions, in particular, the necessity to prepare and publicize scientific works, to contribute comprehensively to scientific, ethnographic researches on history of Ukrainian state formation and liberation movement.

The article attempts brief historical and legal analysis of processes of state formation on the way to uniting Ukrainian people and lands with the beginning of the Ukrainian revolution.

It began after February revolution of 1917 in Petrograd with public organizations and political parties emerged from underground, Ukrainian Central Rada (hereafter referred to as UCR), started formatting at the beginning of March. UCR was created as "parliamentary-type organization" [2]. To make it "the true representation of all organized Ukrainian people", in April, 1917 the National Congress was convened [3]. The Congress defined the structure of state in Ukraine as national-territorial autonomy in the federal democratic Russia, with the main principles of autonomy. The Congress joined the composition of the UCR, chose its head - M. Hrushevsky. Subsequently, at V and VI sessions, as a result of a new reorganization and replenishment of the composition of the territorial and party representation, as well as at the expense of elected members from military, public, trade union organizations, national minorities, the UCR already had 643 deputies [3]. In reality, significantly fewer deputies were involved in its work. Political parties of social nature determined the activities of Central Rada: among 19 parties (Ukrainian, Russian and Polish) 17 considered themselves socialist. This shaped the direction and content of state formation was being made by the UCR and its government. V. Vinnichenko recalled: "This was the center to which all the springs of the awakened national energy flooded; all the pities, all injustices, all hopes, expectations, plans, calculations, and arguments flooded here. "[4].

Despite counteractions and neutral policies of Russian Provisional Government, the UCR gradually was taking over the management of all affairs in Ukraine. Rada's activists tried to defend interests of Western Ukrainians. Reporting at the meeting of its Committee in April and July D. Doroshenko, appointed by the Territorial Commissioner of the Parts of Galicia and Bukovina occupied by Russian troops, spoke about the frightening situation of "humanity deprived of rights", his unproductive attempts to restore economic and cultural life in the country. Rada outlined the priority measures in helping Galician emigrants and prisoners in Siberia [3].

However, the desire of Central Rada to legitimately gain Ukrainian autonomy in the federal democratic Russia reflected in I and II Universals of Rada faced a decisive opposition from Provisional Government. The principle of state formation declared by activists in I Universal "without separating from whole Russia, without breaking up with the Russian state" [3] negatively affected its pace, hampered solu- 
tions of very important social and economic issues. It may seem strange for today, but the matter of future prosperity of the Russian state in plans and events of Rada's activists overpowered a search for solutions. In September 8, 1917 in Kyiv, there was the congress of representatives of peoples and regions of Russia, convened by the Central Rada. Its delegates strived for "federate reorganization of Russian republic", planned to end "excessive centralization of legislative and executive power" [5]. For further work, even the Council of People was elected. However, Russian Provisional Government in Petrograd did not respond to this event, and hopes about democratic reorganization of Russia and democratic solution to the Ukrainian issue remained an illusion.

\section{FEATURES OF FORMATION OF UPR OWN LEGAL SYSTEM}

October Rebellion under the leadership of Bolsheviks and overthrow of Russian Provisional Government accelerated processes of state formation in Ukraine. The adopted Third Universal of UCR proclaimed the Ukrainian People's Republic, the total authority of Central Rada and its General Secretariat [3]. In such way, the Ukrainian statehood was restored.

The formation of UPR own legal system started. Rada issued laws in the name of UPR; the government had the right to "issue orders in the scope of government on the basis of laws". The final delimitation of UPR, the accession of "adjacent provinces and regions, where the majority of population is Ukrainian-speaking" should be "established in agreement with the organized will of people" [3; 5]. The leaders of Ukrainian revolution did not see close prospects for the collapse of the Austro-Hungarian Empire and the unification of the Ukrainian people in one state. In addition, political events at Naddnipranschina became more complicated.

At the Congress of Workers 'and Peasants' Deputies of Donbass and Kryvorizhya in Kharkiv in December 12, 1917, delegates proclaimed the authority of Soviet in Ukraine. The Central Executive Committee of the Soviets was elected, and the Soviet government was formed. In resolutions "On the organization of power in Ukraine", "On self-determination of Ukraine", the Congress of Soviets instructed the Provisional Central Executive Committee "to extend to the territory of the Ukrainian republic all decrees and orders of the workers and peasants government of the Russian Federation." USSR was recognized as the part of Russian Republic [6].

The last Ninth session of the UPR was on January 15-25, 1918 in the conditions of Bolshevik troops attack on Kyiv and the Arsenal factory workers' uprising organized by the Bolsheviks. Under the influence of these events, the leadership of the Central Council finally lost the illusion of the possibility of establishing a Russian democratic federal republic and UPR joining it. Peace negotiations in Brest and Ukrainian delegation desire to sign a peace treaty with the countries of the Quadruple Alliance made necessary constitution of the Ukrainian People's Republic as a subject of international 
law. That is why the session adopted the last Forth Universal, stating in it "From now Ukrainian People's Republic is independent, free, sovereign state of Ukrainian People". M. Hrushevsky hoped that proclaimed independence "would become the solid basis of our statehood and social building" [3;5]. It was indeed crucial state step on the way to the unity of Ukraine.

The ninth session of the UPR empowered the Ukrainian delegation to sign in Brest the peace treaty with Germany, Austro-Hungary, Turkey and Bulgaria. It was signed on January 27, 1918. It was the first peace treaty in the First World War. It consolidated (art.1) the desire of the parties "to live in peace and friendship" [3]. Agreements on the exchange of prisoners, the establishment of diplomatic relations, the exchange of "remnants" of products, etc. were reached. The additional terms of the Brest Treaty were armed assistance to the UPR to fight the Bolsheviks and loan in the amount of 1 billion rubles in exchange for 1 million tons of food, coal and other supplies from Ukraine. [3]. This was the price Central Rada paid for peace and return to power.

For the UPR delegation in Brest it was important question concerning perspectives of joining all lands inhabited by ethnic Ukrainians in the West. However, the delegation had to agree on a secret agreement with Austria-Hungary "on the case of Eastern Galicia and Bukovina," according to which the Austrian side promised to ensure the cultural development of Western Ukrainians, and by July 31, 1918, to unite the West Ukrainian lands "in one single crown edge "[3].

As we see, the UCR activists for a unjustifiably long time were trying to gain the legal status of Ukrainian autonomy within the Russian Federation, which delayed and slowed down the democratic state formation in Ukraine, the solution of urgent social and economic issues. Attracting German and Austrian military aid led to the actual occupation of Ukraine, its robbery and, as a consequence, to the final loss of public confidence in the Central Rada. The promise of the Austro-Hungarian government on the unification of Western Ukrainian lands remained weak consolation.

Under the foreign and Soviet domination, when Central Rada was in Volyn', predominant amount of adopted acts did not come into force. Its last legal act, adopted on April 29, 1918 after Rada returning return to Kyiv, was the Constitution of the UPR "The Statute on the State System, the Rights and Freedoms of the UPR". The Constitution proclaimed the UPR State as a sovereign, independent, whose territory is indivisible [3]. The Basic Law generalized the annual state formation experience, took into account its achievements and disadvantages.

The existence of the Ukrainian state in the conditions of the hetman regime and the German occupation, and then the appearance of "Federal Diploma" by P. Skoropadsky on November 14, 1918 in a certain way compromised the idea of Ukrainian unity. But she revived and gained strength among the opposition political parties, Western Ukrainians. 


\section{WEST UKRAINIAN PEOPLE'S REPUBLIC UNDER THE AUTHORITY OF STATE SECRETARIAT}

In the middle of October 1918, the association of political parties Ukrainian National Union unveiled "Statement on the Internal and External Situation of Ukraine", in which it called it quite natural and necessary to "unite in the one state Ukrainian organism all the inhabited by Ukrainians lands that, by this time and international circumstances, did not form part of the Ukrainian state, that are Eastern Galicia, Bukovina, part of Hungarian Ukraine, Kholmshchyna, Pidlyassya, parts of Bessarabia with the Ukrainian population, part of the ethnographic Ukrainian Donschyna, Montenegro and Kuban "[7]. Believing in a close perspective on the implementation of the communist idea, they gave a sense of the immortal unity of Ukrainians among intellectuals, the democratic wing of political parties, and the rapid development of dramatic political events in Western Ukraine.

On October 18, 1918, Ukrainian deputies of both chambers of the Austrian Parliament, regional districts, representatives of Ukrainian political parties, clergy and students came to Lviv. At the meeting, the Ukrainian National Rada was established, its Charter was approved, its membership was determined, its head was declared - E. Petrushevich [8]. The next day, the "Proclamation of the Ukrainian People's Republic" (Manifesto) was published, which established the territory of the republic, constituting the Ukrainian state [8].

With the collapse of Austria-Hungary on November 1, 1918 Sich Riflemen led by D. Vitovsky handed over power in Lviv, while the deputy governor of Galicia and the delegation of Rada signed an act on the transfer to her full authority in the country. This decision of November 1918 was also supported in Chernivtsi, but by the end of November, Romanian troops occupied the territory of Bukovina [8]. In November 9, Rada formed State Secretariat (government), and also defined the official name of the state the West Ukrainian People's Republic. The next day, Rada adopted a resolution mandating the State Secretariat to take measures to begin negotiations on "the unification of all Ukrainian lands into a single state" [9]. Three days later, she adopted the First Provisional Basic Law, initiating state formation on a constitutional basis. The main task of state formation was the leaders of WUPR considered an association with Naddnipranschina, the unity of the Ukrainian lands.

In November 24, 1918 State Secretariat of WUPR decided to start negotiations about uniting with the Directorate of the UPR, which headed the uprising against the Hetman's regime. On December 1, 1918 delegation of the Ukrainian National Rada of WUPR and Directorat, whose troops were attacking Kyiv, conducted in Fastov the Pre-accession agreement on the unification of 2 parts of Ukraine "into one indivisible state unit" [8]. It was assumed that the WUPR would receive territorial autonomy, and the "joint commission" will determine the boundaries of this autonomy and the detailed 
conditions of the unions of the two republics. Thus, the real prospect of the reunification of most of the Ukrainian lands, mutual support and assistance has become real.

In the unifying movement, the Ukrainians of Transcarpathia took an active part. On the basis of the initiative of the public association "Ruska Narodna Rada", a congress of delegates of its branches (about 500) was convened in Budapest on December 10, most of whom were in favor of joining the region to Ukraine [10]. The same decision was adopted by the Nationwide meeting in Khust on January 21, 1919. [8] The Hutsul republic was even proclaimed in Hutsulschina, and a parliament of 42 deputies was elected. However, the proclamation of the Hungarian Soviet Republic in March of the same year put an end to democratic processes in Ukraine [11].

In January 3, 1919 in Stanislav at the meeting of Ukrainian People's Council, the Decree on the unification of the WUPR and the UPC.was unanimously approved. By declaring their unification unanimously "in one uniform, sovereign People's Republic" the Council made a final decision on this matter at the forthcoming All-Ukrainian Constituent Assembly [8]. Before their convocation in the WUPR, UP Council had the legislative power, the State Secretariat had the executive power, an independent command of the Army was kept. The decision of the UP Council was supported by thousands of manifestations in many cities of the region - in Drohobych, Ternopil, Stryi, Zolochiv, Zhovkva, Kolomyia, Kalush and others. Even the elections to the Central People's Rada (Parliament) of 100 deputies were held [8]

Act Zluky had to be proclaimed in Kyiv. In order to do this, to the capital, where the Directorate of the UPR already had control, a delegation was sent from representatives of Galicia, Bukovina and Transcarpathia.

On January 22, 1919 on the decorated Sofia square of Kiev, in the presence of tens of thousands of people member of the UN Council on behalf of the western Ukrainians L. Bachinsky congratulated people of Kyiv. State Secretary of the WUPR L. Tsegelsky solemnly unveiled the Council's decision on the unification, powers of the Western Ukrainian delegation and handed over the documents to the Head of the Directorate, V. Vinichenko who welcomed the delegation of the brothers and accepted the statement-decision of the Council. The Universal of the Directory was read, in which it was proclaimed: "From now two parts of Ukraine, which for centuries were separated, are joined - the Western-Ukrainian Republic (Galicia, Bukovina, Hungarian Rus) and the Great Naddnipryanska Ukraine" $[8 ; 12 ; 13 ; 14]$.

Eternal dreams, for which the best sons of Ukraine lived and died, came true. “...From now there is the only independent Ukrainian People's Republic. From now Ukrainian people, liberated by the powerful impulse of their own forces, have the opportunity by united, friendly efforts of all sons to build an inseparable, independent Ukrainian state for the good and happiness of all of their labor people "[8]. This "holiday of unification", according to V. Vinichenko, became a significant event in the history of the native state formation [4]. It was truly a majestic national holiday of reunion, the unity of the Ukrainian lands, which were for the long centuries uncovered by neighboring states. 
The next day, a session of the Congress of Labor People of Ukraine, elected in January, was opened, and the Western Ukrainian delegation as a representative from Western Ukraine participated in the work [15]. The first question heard by the Congress was the question of unity. It approved the whole package of the unity documents by adopting the Act of Association and the Universal "To the Ukrainian People". WUPR, in accordance with the Law "On the Form of Government in Ukraine", became known as the Western Region of the UPR. The Congress instructed the government to prepare a draft electoral law for the future national parliament of the independent Ukrainian republic [8].

\section{CONCLUSIONS}

Therefore, the Congress as authorized representative body, "pre-parliament" embodies sovereign Ukraine. In this legal way, the historical problem of uniting both parts of Ukraine was solved. The Labor Congress expressed protest on attempts against integrity, sovereignty and independence of Ukrainian People's Republic. It proclaimed: "Ukrainian people want to be neutral and in friendly relations with all other nations." and pointed out the threat from the side of "imperialists and Soviet Russia". Historical Act Zluky was devoted to the anniversary of the proclamation of the UPR Unity by the Fourth Universal. That is why in January 24, 1919 the Council of People's Directors of Directorate decided to set in January 22 annual celebration of the Day of Unification of Ukraine. In such way, the unity of Ukrainian people and its lands since Kievan Rus' was proclaimed and consolidated.

Act Zluky clearly demonstrated the impotence of attempts to separate Ukrainian nation, to turn parts of Ukraine against each other in the First World War, to force to serve alien purposes [16]. However, further, tragic for Ukraine, events and consequences of Second World War consolidated by the Treaty of Versailles of 1919 for a long time delayed actual process of uniting all Ukrainian lands. Another separating factor, which should be remembered, is functioning of two systems of power in UPR and WUPR. That is why in the most difficult moments of struggle against the invaders, representatives of both powers often could not understand each other, give up own regional interests for the benefit of all Ukraine. In such way, the history of Ukraine is instructive: it is the constitutional duty of every citizen to strive for unity, unanimity in relation to the Motherland, to protect it, especially, in the context of the war with foreign aggression. Historical experience warns that national interests are much more important that interests of party or corporation, the development of a legal, social, democratic state in Ukraine requires the political and spiritual unity of all citizens.

\section{REFERENCES}

[1] About the events marking the 100th anniversary of the events of the Ukrainian Revolution of 1917-1921. Retrieved from http: //zakon.rada.gov.ua/laws/show/17/2016/print/ sp:max100.

[2] Doroshenko, D. (1969). My memories of the recent past (1914-1920). Munich: Ukrayinske vydavnytstvo. 
[3] Verstiuk, V. F. (1996). Ukrainian Central Rada. Documents and materials. Kyiv: Naukova Dumka.

[4] Vinnychenko, V. (1920). Revival of the nation. Kyiv: Dzvin.

[5] Grushevsky, M. (1991). On the threshold of a new Ukraine: Gadgets and dreams. Kyiv: Naukova Dumka.

[6] Ivanov, Yu.O. (1932). Resolutions of the All-Ukrainian Congresses of the Soviets of Workers, Peasants and Red Army Deputies. Kharkiv: Proletarian.

[7] Soldatenko, V. F., Verstyuk, V. F. (2003). Political History of Ukraine of the XX Century. Kyiv: Genesis.

[8] Prilyuk, Yu., Yanevsky, D. (1992). Constitutional Acts of Ukraine. 1917-1920. In Unknown to the constitution of Ukraine. Kyiv: Filosofska i sotsiolohichna dumka.

[9] Tishchik, B. I. (2003). Western Ukrainian People's Republic (1918-1923). In History of state and law. Lviv: Triada plyus.

[10] Kuras, I. F. (1999). Ukrainian catholicity: idea, experience, problems. (To the 80th anniversary of the Unification Act of January 22, 1919). Kyiv: IPiEND.

[11] Sandor, V. (1992). Transcarpathia: historical and legal essay from the XI century. till 1920. New York: Carpathians Union Inc.

[12] Mazepa, I. (1950). Ukraine in the fire and storm of the revolution of 1917-1921. Central Council-Hetmanate - Directory. Kyiv: Prometheus.

[13] Kopylenko, O., Kopylenko, M. (1996). "Second" UPR: attempt of historical-theoretical analysis. Law of Ukraine, 8, 54-60.

[14] Litvin, V. (2006). Unity of the Nation.Veche, 3-4, 34-39.

[15] Hrushevsky, M. (1991). Who are Ukrainians and what they want. Kyiv: Znannya.

\section{William Elliott Butler}

Professor

School of Law

University of Pennsylvania

19104, 34 Chestnut Str., Philadelphia, USA

\section{Victor M. Yermolaiev}

Doctor of Law, Professor

Academician of the National Academy of Legal Sciences of Ukraine

61024, 70 Pushkinskaya Str., Kharkiv, Ukraine

Director of the Institute of Postgraduate Education

Yaroslav Mudryi National Law University

61024, 77, Pushkinskaya Str., Kharkiv, Ukraine

Suggested Citation: Butler, W. E., \& Yermolaiev, V. M. (2019). Towards the course of Ukraine (to the 100th anniversary of the act of unification of the UPR with ZUNR). Journal of the National Academy of Legal Sciences of Ukraine, 26 (1), $166-174$.

Submitted: $30 / 01 / 2019$

Revised: $11 / 03 / 2019$

Accepted: 28/03/2019 


\title{
Journal \\ of the National Academy of Legal Sciences of Ukraine
}

\author{
Volume 26, Issue 1 \\ 2019
}

Responsible for the release of $O$. V. Petryshyn

Desktop publishing O. Fedoseeva

Signed to the print with the original layout 17.05.2019.

Format $70 \times 1001 / 16$. Offset paper. Headset Times.

Mind. print. ark. 14,2. Acc. publ. ark. 12,5. No. 2209.

Edition of 250 copies.

The publisher the Right of National Academy of legal Sciences of Ukraine and the Yaroslav Mudryi National Law University 61002, 80A Chernyshevskaya Street, Kharkiv, Ukraine Tel/Fax: (057) 716-45-53

Website: www.pravo-izdat.com.ua e-mail for authors: verstka@pravo-izdat.com.ua e-mail for orders: sales@pravo-izdat.com.ua

Certificate of registration of the subject of publishing in the state register of publishers, manufacturers and distributors of publishing products series DK No. 4219 dated 01.12.2011

Made in the printing PE Leonov D. S.

Ph.: (057) 717-25-44 


\title{
Вісник \\ Національної академії правових наук України
}

\author{
Toм 26, № 1 \\ 2019
}

(Англійською мовою)

Відповідальний за випуск $О$. В. Петришин

Комп’ютерна верстка О. А. Федосєєвої

Підписано до друку з оригінал-макета 17.05.2019. Формат 70×100 11/16. Папір офсетний. Гарнітура Times. Ум. друк. арк. 14,2. Обл.-вид. арк. 12,5. Вид. № 2209.

Тираж 250 прим.

Видавництво «Право» Національної академії правових наук України та Національного юридичного університету імені Ярослава Мудрого вул. Чернишевська, 80а, Харків, 61002, Україна Тел./факс (057) 716-45-53

Сайт: www.pravo-izdat.com.ua

E-mail для авторів: verstka@pravo-izdat.com.ua

E-mail для замовлень: sales@pravo-izdat.com.ua

Свідоцтво про внесення суб'єкта видавничої справи до державного реєстру видавців, виготівників і розповсюджувачів видавничої продукції — серія ДК № 4219 від 01.12.2011р.

Виготовлено у друкарні ФОП Леонов Д. С.

Тел. (057) 717-25-44 